\title{
AGR-2 Safety-Tested UCO Compact 6-4-2 PIE Report
}

Approved for public release Distribution is unlimited
John D. Hunn

Tyler J. Gerczak

Fred C. Montgomery

Darren J. Skitt

Charles A. Baldwin Grant W. Helmreich

Brian D. Eckhart John A. Dyer

May 2018 


\section{DOCUMENT AVAILABILITY}

Reports produced after January 1, 1996, are generally available free via US Department of Energy (DOE) SciTech Connect.

Website http://www.osti.gov/scitech/

Reports produced before January 1, 1996, may be purchased by members of the public from the following source:

National Technical Information Service

5285 Port Royal Road

Springfield, VA 22161

Telephone 703-605-6000 (1-800-553-6847)

TDD 703-487-4639

Fax 703-605-6900

E-mail info@ntis.gov

Website http://www.ntis.gov/help/ordermethods.aspx

Reports are available to DOE employees, DOE contractors, Energy Technology Data Exchange representatives, and International Nuclear Information System representatives from the following source:

Office of Scientific and Technical Information

PO Box 62

Oak Ridge, TN 37831

Telephone 865-576-8401

Fax 865-576-5728

E-mail reports@osti.gov

Website http://www.osti.gov/contact.html

This report was prepared as an account of work sponsored by an agency of the United States Government. Neither the United States Government nor any agency thereof, nor any of their employees, makes any warranty, express or implied, or assumes any legal liability or responsibility for the accuracy, completeness, or usefulness of any information, apparatus, product, or process disclosed, or represents that its use would not infringe privately owned rights. Reference herein to any specific commercial product, process, or service by trade name, trademark, manufacturer, or otherwise, does not necessarily constitute or imply its endorsement, recommendation, or favoring by the United States Government or any agency thereof. The views and opinions of authors expressed herein do not necessarily state or reflect those of the United States Government or any agency thereof. 
Fusion and Materials for Nuclear Systems Division

\title{
AGR-2 SAFETY-TESTED UCO COMPACT 6-4-2 PIE REPORT \\ Evaluation of Fuel Performance with Leach-Burn-Leach, IMGA, X-ray Tomography, and Materialography
}

\author{
John D. Hunn \\ Tyler J. Gerczak \\ Fred C. Montgomery \\ Darren J. Skitt \\ Charles A. Baldwin \\ Grant W. Helmreich \\ Brian D. Eckhart \\ John A. Dyer
}

Date Published: May 2018

\author{
Work sponsored by \\ US DEPARTMENT OF ENERGY \\ Office of Nuclear Energy - Advanced Reactor Technologies \\ under the \\ Advanced Gas Reactor Fuel Development and Qualification Program
}

Prepared by

OAK RIDGE NATIONAL LABORATORY

Oak Ridge, TN 37831-6283

managed by

UT-BATTELLE, LLC

for the

US DEPARTMENT OF ENERGY

under contract DE-AC05-00OR22725 



\section{CONTENTS}

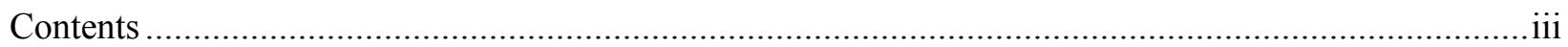

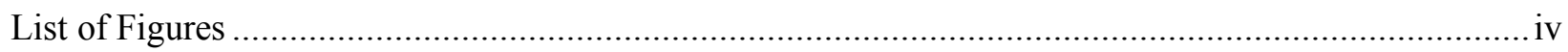

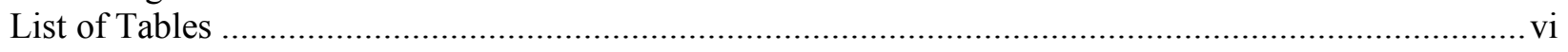

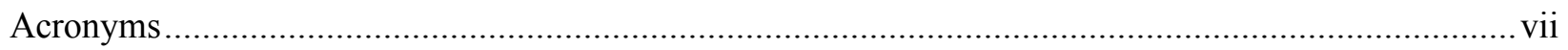

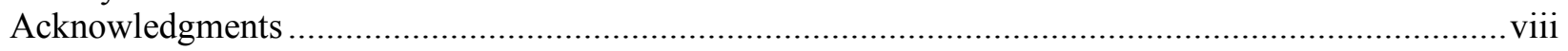

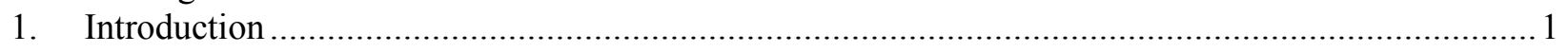

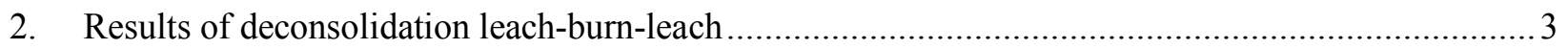

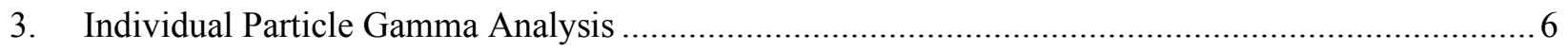

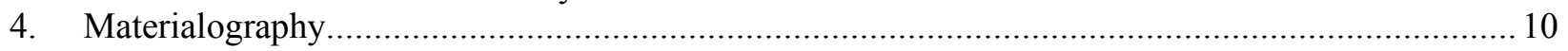

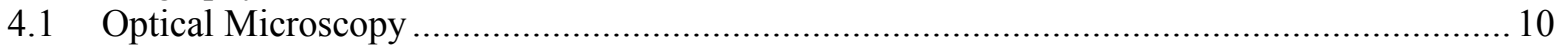

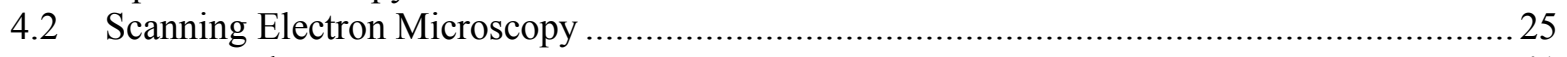

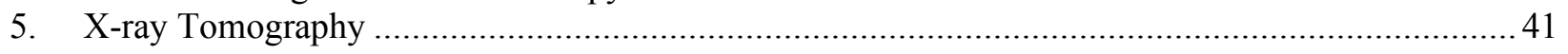

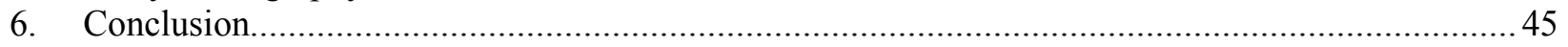

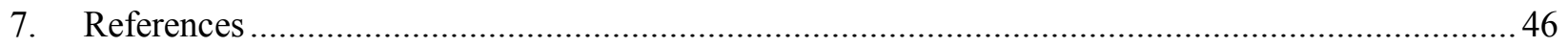




\section{LIST OF FIGURES}

1. Ratio of ${ }^{110 \mathrm{~m}} \mathrm{Ag}$ retained in 43 particles versus the calculated inventory, adjusted for variation in fissionable material and burnup with the measured ${ }^{137} \mathrm{Cs}$ activity. Particles plotted as "zero" had a ${ }^{110 \mathrm{~m}} \mathrm{Ag} \mathrm{M} / \mathrm{C} \lesssim 33 \%$.

2. Ratio of ${ }^{144} \mathrm{Ce}$ retained in 43 particles versus the calculated inventory, adjusted for variation in fissionable material and burnup with the measured ${ }^{137} \mathrm{Cs}$ activity........................... 7

3. Ratio of ${ }^{154} \mathrm{Eu}$ retained in 43 particles versus the calculated inventory, adjusted for variation in fissionable material and burnup with the measured ${ }^{137} \mathrm{Cs}$ activity........................... 7

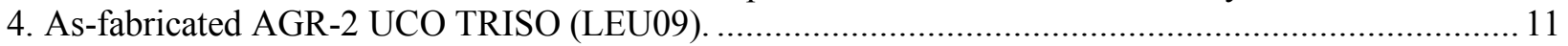

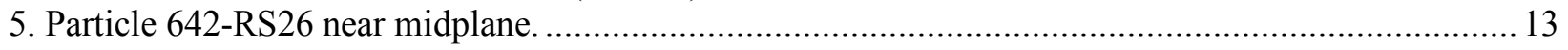

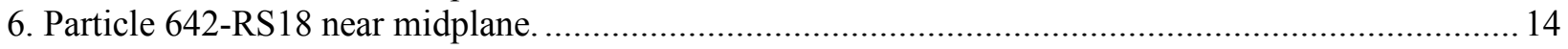

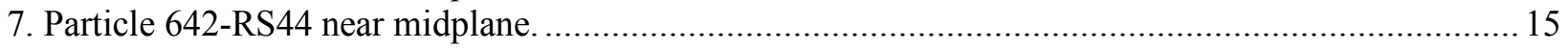

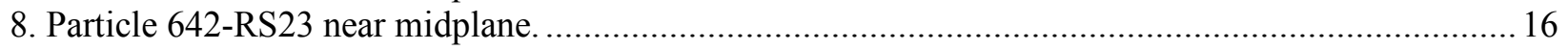

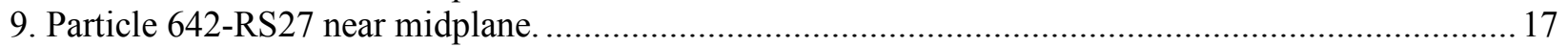

10. Images of randomly-selected particles from multiparticle mount MM-E10 ................................... 18

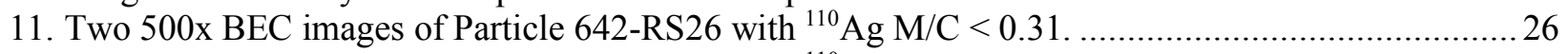

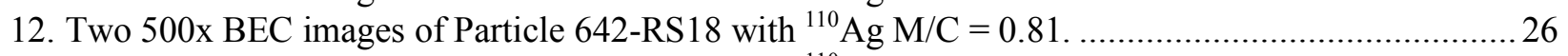

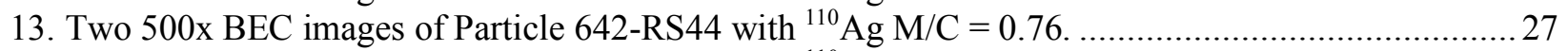

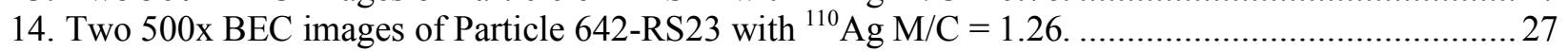

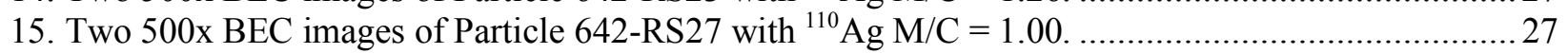

16. Comparision of SE and BEC image pairs of Particle $642-\mathrm{RS} 26\left({ }^{110} \mathrm{Ag} \mathrm{M} / \mathrm{C}=0.31\right)$ showing several unusually-large $\mathrm{SiC}$ features on IPyC side of the IPyC/SiC

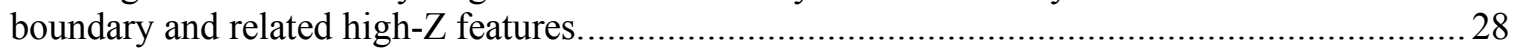

17. Comparision of SE and BEC image pairs of low-silver Particle 642-RS26 showing embedded high- $\mathrm{Z}$ features on both sides of the $\mathrm{IPyC} / \mathrm{SiC}$ boundary. .....................................28

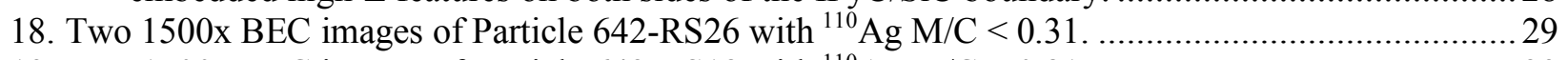

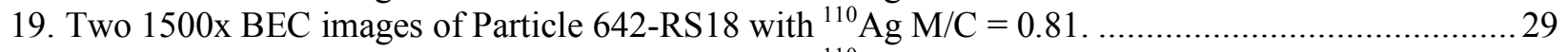

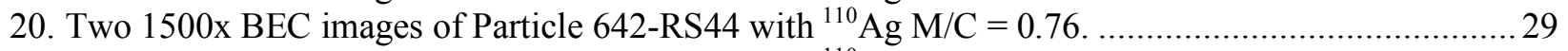

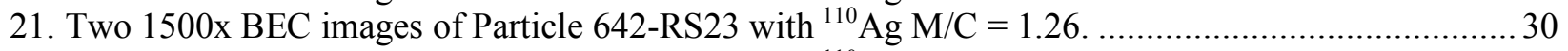

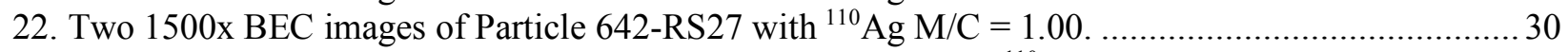

23. Comparision of SE and BEC image pairs of Particle $642-\mathrm{RS} 18\left({ }^{110} \mathrm{Ag} \mathrm{M} / \mathrm{C}=0.81\right)$

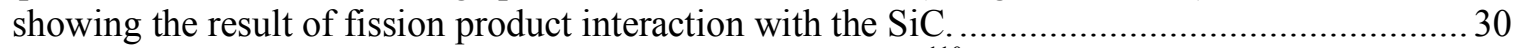

24. Comparision of SE and BEC image pairs of Particle $642-\mathrm{RS} 44\left({ }^{110} \mathrm{Ag} \mathrm{M} / \mathrm{C}=0.76\right)$ showing the result of fission product interaction with the SiC ............................................ 31

25. Comparision of SE and BEC image pairs of Particle $642-\mathrm{RS} 44\left({ }^{110} \mathrm{Ag} \mathrm{M} / \mathrm{C}=0.76\right)$ showing the result of fission product interaction with the SiC .............................................. 31

26. Comparision of SE and BEC image pairs of Particle $642-\mathrm{RS} 23\left({ }^{110} \mathrm{Ag} \mathrm{M} / \mathrm{C}=1.26\right)$ showing the result of fission product interaction with the $\mathrm{SiC}$.

27. Pd-only and Pd-U features in the SiC layer of low-silver Particle 642-RS26

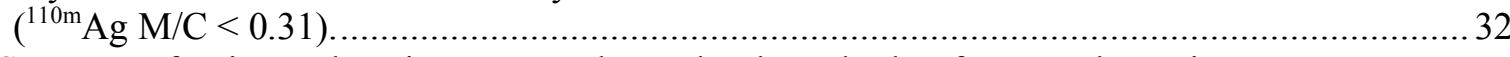

28. EDS spectra of Point-ID locations centered on Pd-only and Pd-U features shown in

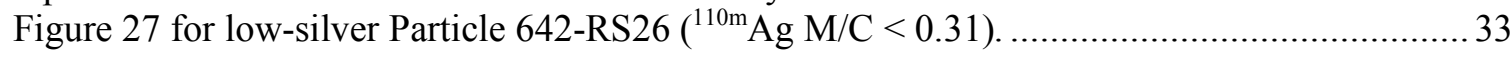

29. EDS spectra of Point-ID locations centered on Pd-U features shown in Figure 27 for

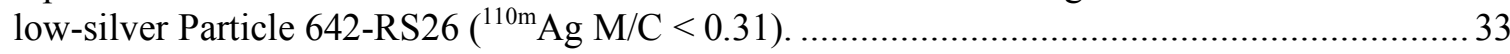

30. $\mathrm{U}-\mathrm{Zr}$ features at the IPyC/SiC boundary of low-silver Particle 642-RS26 $\left({ }^{110 \mathrm{~m}} \mathrm{Ag} \mathrm{M} / \mathrm{C}<0.31\right)$..

31. EDS spectra of Point-ID locations centered on U-Zr feature shown in Figure 30 for low-silver Particle 642-RS26 $\left({ }^{110 \mathrm{~m}} \mathrm{Ag} \mathrm{M} / \mathrm{C}<0.31\right)$.

32. Pd-U feature in the IPyC near the IPyC/SiC boundary of low-silver Particle 642-RS26 $\left({ }^{110 \mathrm{~m}} \mathrm{Ag} \mathrm{M} / \mathrm{C}<0.31\right)$.

33. EDS spectra of Point-ID locations centered on Pd-U feature shown in Figure 32 for low-silver Particle 642-RS26 $\left({ }^{110 \mathrm{~m}} \mathrm{Ag} \mathrm{M} / \mathrm{C}<0.31\right)$. 
34. EDS spectra of Pd-U IPyC near the IPyC/SiC boundary for low-silver Particle 642-RS26 and high-silver Particle 642-RS27.

35. Pd-U features at the IPyC/SiC boundary and near the boundary on either side for average-silver Particle 642-RS44 $\left({ }^{110 \mathrm{~m}} \mathrm{Ag} \mathrm{M} / \mathrm{C}=0.76\right)$.

36. EDS spectra of Point-ID locations centered on Pd-U features shown in Figure 35 for average-silver Particle 642-RS44 $\left({ }^{110 \mathrm{~m}} \mathrm{Ag} \mathrm{M} / \mathrm{C}=0.76\right)$.

37. Pd-U features at the IPyC/SiC boundary for average-silver Particle 642-RS18 $\left({ }^{110 \mathrm{~m}} \mathrm{Ag} \mathrm{M} / \mathrm{C}=0.81\right)$.

38. EDS spectra of Point-ID locations centered on features shown in Figure 37 for average-silver Particle 642-RS18 $\left({ }^{110 \mathrm{~m}} \mathrm{Ag} \mathrm{M} / \mathrm{C}=0.81\right)$.

39. $\mathrm{Pd}-\mathrm{U}$ features in the locally-elevated, high-Z region near the $\mathrm{IPyC} / \mathrm{SiC}$ boundary of average-silver Particle 642-RS44 $\left({ }^{110 \mathrm{~m}} \mathrm{Ag} \mathrm{M} / \mathrm{C}=0.76\right)$.

40. EDS spectra of Point-ID locations centered on Pd-U features shown in Figure 39 for average-silver Particle 642-RS44 $\left({ }^{110 \mathrm{~m}} \mathrm{Ag} \mathrm{M} / \mathrm{C}=0.76\right)$

41. U-IPyC features in high-silver Particle 642-RS23 $\left({ }^{110 \mathrm{~m}} \mathrm{Ag} \mathrm{M} / \mathrm{C}=1.26\right)$.

42. EDS spectra of Point-ID locations centered on IPyC features shown in Figure 41 for high-silver Particle 642-RS23 $\left({ }^{110 \mathrm{~m}} \mathrm{Ag} \mathrm{M} / \mathrm{C}=1.26\right)$ and $\mathrm{U}-\mathrm{Zr}$ feature in IPyC of low-silver Particle 642-RS26.

43. Orthogonal oblique tomograms through center of Particle 642-RS28.........................................42

44. Orthogonal oblique tomograms through center of Particle 642-RS16....................................... 43

45. Orthogonal oblique tomograms through center of Particle 642-RS35. 


\section{LIST OF TABLES}

1. Irradiation conditions for AGR-2 UCO Compact 6-4-2 ….....................................................2

2. Exposed compact inventory fractions ${ }^{a}$ of $\mathrm{U}$ and $\mathrm{Pu}$ detected by DLBL ....................................... 3

3. Exposed compact inventory fractions ${ }^{a}$ of typically-tracked beta/gamma-emitting

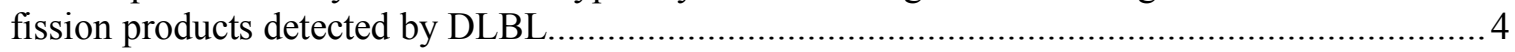

4. Exposed compact inventory fractions ${ }^{a}$ of stable isotopes of interest detected by DLBL ...................... 5

5. Summary of results from 6-hour IMGA analysis of Compact $6-4-2$ particles ..................................... 8

6. Results of 6-hour gamma scanning of 43 randomly-selected (RS) particles showing measured activity $(\mathrm{Bq} /$ particle decay-corrected to $\mathrm{EOL}+1$ day) ............................................ 8

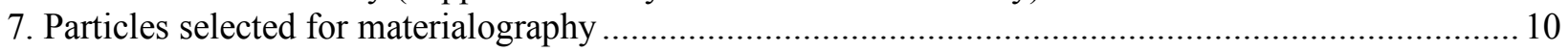

8. Particles selected for $\mathrm{x}$-ray tomography ............................................................................... 41

9. Ratio of measured versus average measured activity for particles selected for x-ray tomography..... 


\section{ACRONYMS}

AGR Advanced Gas Reactor (Fuel Development and Qualification Program)

AGR-1

AGR-2

ATR

BEC

BWXT-NOG

CCCTF

$\mathrm{CO}$

DLBL

EDS

FIMA

HTGR

ID

IFEL

IMGA

INL

$\mathrm{M} / \mathrm{C}$

$\mathrm{OPyC}$

ORNL

PGS

PIE

SE

SEM

$\mathrm{SiC}$

$\mathrm{TA}_{\min }$

$\mathrm{TA}_{\max }$

TAVA

TRISO

UCO

$\mathrm{UO}_{2}$

$\mathrm{Z}$
First AGR program irradiation experiment

Second AGR program irradiation experiment

Advanced Test Reactor

Backscattered-electron composition

BWX Technologies Nuclear Operations Group

Core Conduction Cooldown Test Facility

Carbon monoxide

Deconsolidation leach-burn-leach

Energy-dispersive x-ray spectroscopy

Fissions per initial metal atom

High Temperature Gas-cooled Reactor

Identification

Irradiated Fuels Examination Laboratory (hot cells)

Irradiated Microsphere Gamma Analyzer

Idaho National Laboratory

Measured versus calculated isotopic activity (adjusted for fissile inventory and burnup)

Outer pyrolytic carbon (TRISO layer)

Oak Ridge National Laboratory

Precision Gamma Scanner

Post-irradiation examination

Secondary electron

Scanning electron microscope

Silicon carbide (TRISO layer)

Time-averaged minimum temperature

Time-averaged maximum temperature

Time-averaged/volume-averaged temperature

Tristructural-isotropic (coated particles)

Uranium carbide/uranium oxide mixture (fuel kernels)

Uranium dioxide (fuel kernels)

Atomic number 


\section{ACKNOWLEDGMENTS}

This work was sponsored by the U.S. Department of Energy, Office of Nuclear Energy, through the Idaho National Laboratory Advanced Reactor Technologies Technology Development Office as part of the Advanced Gas Reactor Fuel Development and Qualification Program. Analysis of leach solutions was provided by the Oak Ridge National Laboratory Nuclear Analytical Chemistry \& Isotopics Laboratory. Hot cell activities were supported by the staff of the Oak Ridge National Laboratory Irradiated Fuels Examination Laboratory (IFEL). 


\section{INTRODUCTION}

As discussed in a previous report [Hunn et al. 2016] and reproduced in the following four paragraphs to provide background information and common terminology, post-irradiation examination (PIE) is being performed on tristructural-isotropic (TRISO) coated-particle fuel compacts from the Advanced Gas Reactor (AGR) Fuel Development and Qualification Program second irradiation experiment (AGR-2) [Collin 2014]. This effort builds upon the understanding acquired throughout the AGR-1 PIE campaign [Demkowicz et al. 2015] and is establishing a database for the different AGR-2 fuel designs.

The AGR-2 irradiation experiment included TRISO fuel particles coated at BWX Technologies Nuclear Operations Group (BWXT-NOG) with a 150-mm-diameter engineering-scale coater. Two coating batches were tested in the AGR-2 irradiation experiment. Batch 93085 had 508- $\mu$ m-diameter uranium dioxide $\left(\mathrm{UO}_{2}\right)$ kernels. Batch 93073 had $427-\mu \mathrm{m}$-diameter UCO kernels, which is a kernel design where some of the uranium oxide is converted to uranium carbide during fabrication to provide a getter for oxygen liberated during fission and limit CO production. Fabrication and property data for the AGR-2 coating batches have been compiled [Barnes and Marshall 2009] and compared to AGR-1 [Phillips, Barnes, and Hunn 2010]. The AGR-2 TRISO coatings were most like the AGR-1 Variant 3 TRISO deposited in the 50-mm-diameter Oak Ridge National Laboratory (ORNL) lab-scale coater [Hunn and Lowden 2006]. In both cases argon-dilution of the hydrogen and methyltrichlorosilane coating gas mixture employed to deposit the $\mathrm{SiC}$ was used to produce a finer-grain, more equiaxed $\mathrm{SiC}$ microstructure [Lowden 2006; Gerczak et al. 2016]. In addition to the fact that AGR-1 fuel had smaller, 350- $\mu$ m-diameter UCO kernels, notable differences in the TRISO particle properties included the pyrocarbon anisotropy, which was slightly higher in the particles coated in the engineering-scale coater, and the exposed kernel defect fraction, which was higher for AGR-2 fuel due to the detected presence of particles with impact damage introduced during TRISO particle handling [Hunn 2010].

Irradiation test compacts containing AGR-2 fuel particles were compacted at ORNL with the same resinated-graphite blend used to make AGR-1 compacts and a modified pressing process that utilized a die heated to $65^{\circ} \mathrm{C}$ and a new computer-controlled servo-press. Two compact lots were produced and qualified for the AGR-2 irradiation test: lot LEU09-OP2-Z contained the UCO TRISO particles [Hunn, Montgomery, and Pappano 2010a] and lot LEU11-OP2-Z contained the $\mathrm{UO}_{2}$ fuel [Hunn, Montgomery, and Pappano 2010b]. Compared to the AGR-1 compacts, which were compacted at room temperature using a manual press, the modified AGR-2 compacting process produced compacts with reduced variability in length and higher matrix density $\left(1.6-1.7 \mathrm{~g} / \mathrm{cm}^{3}\right.$ for AGR-2 compacts versus $1.2-1.3 \mathrm{~g} / \mathrm{cm}^{3}$ for AGR-1 compacts). Compilations of the properties data for the particles and compacts are available in pre-irradiation characterization summary reports for the AGR-1 [Hunn, Savage, and Silva 2012] and AGR-2 [Hunn, Savage, and Silva 2010] fuel composites.

The AGR-2 Post-Irradiation Examination Plan [Demkowicz 2013] includes shipment of irradiated compacts from the Idaho National Laboratory (INL) to the ORNL for destructive PIE in both the asirradiated condition and after safety testing. This PIE includes deconsolidation leach-burn-leach (DLBL) analysis for exposed fission products, "gamma results from short-counting time gamma surveys performed on all the recovered TRISO particles with the ORNL Irradiated Gamma Microsphere Analyzer (IMGA), results from long-counting time IMGA measurements performed on specially-selected particles that exhibited significant cesium release or other unusual radioisotopic release, and similar IMGA measurements performed on 40-60 randomly-selected particles. Microstructural analysis using X-ray microtomography and materialographic methods are performed to investigate radiation-induced changes in the particles and elucidate the mechanisms responsible for observed fission product release. Materialographic methods typically include mechanical polishing of particle cross section, imaging with

\footnotetext{
* In this report, the term "fission product" is used in a general sense to refer to all the post-fission isotopes remaining at the end of the irradiation test. These include: isotopes directly generated by the fission process, isotopes generated by neutron activation, isotopes generated by radioactive decay, and residual uranium.
} 
an optical microscope, imaging with a scanning electron microscope (SEM), and atomic analysis via energy-dispersive x-ray spectroscopy (EDS).

Safety tests involve heating compacts in flowing helium to maximum temperatures of $1600-1800^{\circ} \mathrm{C}$ and holding at these test temperatures for approximately $300 \mathrm{~h}$. The standard test temperature of $1600^{\circ} \mathrm{C}$ is the expected maximum temperature during a high-temperature gas-cooled reactor (HTGR) depressurization conduction-cooldown event, while $1700^{\circ} \mathrm{C}$ and $1800^{\circ} \mathrm{C}$ tests explore the safety margin and provide additional data on mechanisms for particle coating failure. AGR-2 UCO Compact 6-4-2 was safety tested at $1600^{\circ} \mathrm{C}$ in the ORNL Core Conduction Cooldown Test Facility (CCCTF). Results of this safety test were reported in [Hunn et al. 2017]. The cumulative ${ }^{134} \mathrm{Cs}$ release from Compact 6-4-2 reached $20 \%$ of one particle's inventory by the end of the safety test. This level of cesium release is a factor of 10 greater than expected from a compact with no $\mathrm{SiC}$ failure, but below what is typical for a compact with a failed$\mathrm{SiC}$ particle. No exposed kernels were detected in Compact 6-4-2 during post-safety test DLBL and this led to the conclusion that the relatively-gradual release of cesium that was observed during the $1600^{\circ} \mathrm{C}$ safety test of Compact 6-4-2 was more likely related to abnormal uranium contamination in the matrix.

In this report, results from destructive PIE after $1600^{\circ} \mathrm{C}$ safety testing of AGR-2 UCO Compact 6-4-2 are reported. Compact 6-4-2 was irradiated in the INL Advanced Test Reactor (ATR). Table 1 shows the calculated burnup in percent fissions per initial metal atom (FIMA), the fast neutron fluence (neutron energies $>0.18 \mathrm{MeV}$ ), and calculated compact temperatures during irradiation.

Table 1. Irradiation conditions for AGR-2 UCO Compact 6-4-2

\begin{tabular}{|c|c|c|c|c|c|c|c|}
\hline \multirow{2}{*}{ Compact ID $^{a}$} & \multirow{2}{*}{ Fabrication ID $^{b}$} & \multirow{2}{*}{ Fuel Type } & \multirow{2}{*}{$\begin{array}{c}\text { Average Burnup } \\
\text { (FIMA) }\end{array}$} & \multirow{2}{*}{$\begin{array}{l}\text { Fast Fluence }^{c} \\
(\mathrm{E}>0.18 \mathrm{MeV})\end{array}$} & \multicolumn{3}{|c|}{ Temperature $^{\mathrm{d}}$} \\
\hline & & & & & TAVA & $\mathrm{TA}_{\min }$ & $\mathrm{TA}_{\max }$ \\
\hline AGR-2 6-4-2 & LEU09-OP2-Z049 & $\mathrm{UCO}$ & $9.26 \%$ & $2.21 \cdot 10^{25} \mathrm{n} / \mathrm{m}^{2}$ & $1018^{\circ} \mathrm{C}$ & $894^{\circ} \mathrm{C}$ & $1106^{\circ} \mathrm{C}$ \\
\hline
\end{tabular}

${ }^{a}$ The X-Y-Z compact identification (ID) convention denotes the location in the irradiation test train: Capsule-LevelStack [Collin 2014].

${ }^{b}$ Physical properties data for individual compacts are available and tabulated based on fabrication ID [Hunn, Montgomery, and Pappano 2010a, pages 60-69].

${ }^{c}$ Burnup [Sterbentz 2014, table 6] and fast fluence [Sterbentz 2014, table 12] are based on physics calculations.

${ }^{d}$ Time-averaged, volume-averaged (TAVA) temperature, time-averaged minimum (TAmin) temperature, and timeaveraged maximum $\left(\mathrm{TA}_{\max }\right)$ temperature is based on thermal calculations [Hawkes 2014, table 3 ]. 


\section{RESULTS OF DECONSOLIDATION LEACH-BURN-LEACH}

The DLBL equipment and analysis procedures are described in detail in [Hunn et al. 2013]. After electrolytic deconsolidation and two 24-h pre-burn leaches in a Soxhlet extractor, the particles and matrix debris from Compact 6-4-2 were heated at $750^{\circ} \mathrm{C}$ in flowing air for $\sim 72 \mathrm{~h}$ to burn off any exposed carbon, including the outer pyrocarbon $(\mathrm{OPyC})$ layer. The burned-back particles and any residual ash were subjected to two 24-h post-burn leaches in a Soxhlet extractor. The deconsolidation acid and Soxhlet extraction leachates were analyzed by gamma spectroscopy and mass spectroscopy to identify dissolved fission products.

Table 2 shows data for several isotopes of uranium and plutonium that are typically measured and useful for determining if kernels were exposed to the acid during the DLBL process. Exposed kernels before the burn are associated with defective or failed TRISO coatings and exposed kernels after the burn are related to defective or failed SiC layers, as described in [Hunn et al. 2014]. Deconsolidation and pre-burn leaching detected exposed uranium and plutonium at $1-4 \%$ of one particle-equivalent. This indicates that no kernels were exposed in the safety-tested compact due to defective or failed TRISO. The amount of uranium and plutonium detected in the post-burn particle leach was also $1-3 \%$, indicating no defective or failed SiC.

Table 2. Exposed compact inventory fractions ${ }^{a}$ of $U$ and Pu detected by DLBL

\begin{tabular}{|c|c|c|c|c|c|}
\hline LBL Step & ${ }^{235} \mathbf{U}$ & ${ }^{236} \mathbf{U}$ & ${ }^{238} \mathbf{U}$ & ${ }^{239} \mathrm{Pu}$ & ${ }^{240} \mathrm{Pu}$ \\
\hline Deconsolidation acid & $1.53 \mathrm{E}-6$ & $2.27 \mathrm{E}-6$ & $5.42 \mathrm{E}-6$ & $2.89 \mathrm{E}-6$ & $4.61 \mathrm{E}-6$ \\
\hline Pre-burn leach 1 & $8.04 \mathrm{E}-7$ & $1.18 \mathrm{E}-6$ & $3.27 \mathrm{E}-6$ & $2.76 \mathrm{E}-6$ & $4.60 \mathrm{E}-6$ \\
\hline Pre-burn leach 2 & $4.50 \mathrm{E}-7$ & $7.64 \mathrm{E}-7$ & $3.09 \mathrm{E}-6$ & $2.04 \mathrm{E}-6$ & $3.50 \mathrm{E}-6$ \\
\hline Post-burn particle leach 1 & $2.25 \mathrm{E}-6$ & $2.69 \mathrm{E}-6$ & $4.86 \mathrm{E}-6$ & $6.02 \mathrm{E}-6$ & $7.79 \mathrm{E}-6$ \\
\hline Post-burn particle leach 2 & $4.84 \mathrm{E}-7$ & $5.58 \mathrm{E}-7$ & $1.53 \mathrm{E}-6$ & $1.34 \mathrm{E}-6$ & $2.28 \mathrm{E}-6$ \\
\hline Total & $5.52 \mathrm{E}-6$ & 7.47E-6 & $1.82 \mathrm{E}-5$ & $1.51 \mathrm{E}-5$ & $2.28 \mathrm{E}-5$ \\
\hline Equivalent particle inventory ${ }^{b}$ & 0.018 & 0.024 & 0.058 & 0.048 & 0.072 \\
\hline
\end{tabular}

${ }^{a}$ Compact inventory fractions are the measured grams of each actinide divided by the calculated compact inventory of that actinide one year after the end of the irradiation.

${ }^{b}$ Equivalent particle inventory is the compact fraction times the average number of particles per compact (3176) and provides an indication of the number of exposed kernels; a compact fraction of 3.15E-4 is equivalent to one particle.

Table 3 and Table 4 show the DLBL data for typically-tracked beta/gamma-emitting fission products and some stable isotopes of interest, respectively. Radioisotope release was extremely low with the exception of the europium isotopes. Typically, radioisotopes of silver and europium are released through intact $\mathrm{SiC}$ during irradiation and retained in the compact matrix and/or OPyC at levels higher than most other radioisotopes [Demkowicz et al. 2015]. Safety testing at $1600^{\circ} \mathrm{C}$ drove the silver that was released through intact $\mathrm{SiC}$ during irradiation out of the compact [Hunn et al. 2017], which is a typical result [Morris et al. 2014; Morris et al. 2016]. Therefore, ${ }^{110 \mathrm{~m}} \mathrm{Ag}$ leached during DLBL was low $\left({ }^{109} \mathrm{Ag}\right.$ in the mass spectrometry data indicated some silver remained). In addition to ${ }^{154} \mathrm{Eu}$ and ${ }^{155} \mathrm{Eu}$, other stable lanthanide isotopes, which share similar chemical properties that affect diffusion through $\mathrm{SiC}$, were also detected at moderately-elevated levels. 
Table 3. Exposed compact inventory fractions ${ }^{a}$ of typically-tracked beta/gamma-emitting fission products detected by DLBL

\begin{tabular}{|c|c|c|c|c|c|c|c|c|c|}
\hline LBL Step & ${ }^{90} \mathrm{Sr}^{b}$ & ${ }^{106} \mathrm{Ru}$ & ${ }^{110 m} \mathrm{Ag}$ & ${ }^{125} \mathrm{Sb}$ & ${ }^{134} \mathrm{Cs}$ & ${ }^{137} \mathrm{Cs}$ & ${ }^{144} \mathrm{Ce}$ & ${ }^{154} \mathbf{E u}$ & ${ }^{155} \mathbf{E u}$ \\
\hline Deconsolidation acid & $2.36 \mathrm{E}-6$ & $<9.63 \mathrm{E}-7$ & $<1.43 \mathrm{E}-4$ & $<2.61 \mathrm{E}-6$ & $6.31 \mathrm{E}-7$ & $3.16 \mathrm{E}-6$ & $3.76 \mathrm{E}-7$ & $2.01 \mathrm{E}-5$ & $2.23 \mathrm{E}-5$ \\
\hline Pre-burn leach 1 & $1.66 \mathrm{E}-6$ & $<8.03 \mathrm{E}-7$ & $<1.52 \mathrm{E}-4$ & $<1.71 \mathrm{E}-6$ & $1.66 \mathrm{E}-7$ & $1.54 \mathrm{E}-6$ & $7.56 \mathrm{E}-7$ & 4.94E-5 & $5.25 \mathrm{E}-5$ \\
\hline Pre-burn leach 2 & $8.80 \mathrm{E}-7$ & $<1.34 \mathrm{E}-6$ & $<2.18 \mathrm{E}-4$ & $<3.93 \mathrm{E}-6$ & $<1.36 \mathrm{E}-7$ & $3.52 \mathrm{E}-6$ & $<2.86 \mathrm{E}-7$ & $6.90 \mathrm{E}-6$ & $7.24 \mathrm{E}-6$ \\
\hline Post-burn particle leach 1 & $2.17 \mathrm{E}-6$ & $<2.20 \mathrm{E}-6$ & $<4.17 \mathrm{E}-4$ & $<4.68 \mathrm{E}-6$ & $1.82 \mathrm{E}-6$ & $3.70 \mathrm{E}-6$ & $4.64 \mathrm{E}-6$ & $3.09 \mathrm{E}-4$ & $3.36 \mathrm{E}-4$ \\
\hline Post-burn particle leach 2 & 4.07E-7 & $<6.44 \mathrm{E}-7$ & $<1.06 \mathrm{E}-4$ & $<1.48 \mathrm{E}-6$ & $1.75 \mathrm{E}-7$ & $1.43 \mathrm{E}-6$ & $4.65 \mathrm{E}-7$ & $1.01 \mathrm{E}-5$ & $1.10 \mathrm{E}-5$ \\
\hline Total & $7.48 \mathrm{E}-6$ & & & & $2.79 \mathrm{E}-6$ & $1.34 \mathrm{E}-5$ & $6.24 \mathrm{E}-6$ & $3.96 \mathrm{E}-4$ & $4.29 \mathrm{E}-4$ \\
\hline Equivalent particle inventory $^{c}$ & 0.024 & & & & 0.009 & 0.042 & 0.020 & 1.3 & 1.4 \\
\hline
\end{tabular}

${ }^{a}$ Compact inventory fractions are the measured grams of each radioisotope decay-corrected and divided by the calculated compact inventory of that radioisotope one day after the end of the irradiation. Values that primarily contributed to the total for each isotope are highlighted. Numbers in gray are low compared to possible background. A less than value indicates the concentration in the leachate was below the minimum detectable limit and these values are not included in the totals.

${ }^{b}$ Chemical separation and beta analysis was used to measure ${ }^{90} \mathrm{Sr}$; other isotopes were measured by gamma spectrometry.

${ }^{c}$ Equivalent particle inventory is the compact fraction times the average number of particles per compact (3176); a compact fraction of 3.15E-4 is equivalent to one particle. 
Table 4. Exposed compact inventory fractions ${ }^{a}$ of stable isotopes of interest detected by DLBL

\begin{tabular}{|c|c|c|c|c|c|c|c|c|c|c|}
\hline LBL Step & ${ }^{105} \mathbf{P d}$ & ${ }^{109} \mathrm{Ag}^{b}$ & ${ }^{133} \mathrm{Cs}$ & ${ }^{139} \mathbf{L a}$ & ${ }^{140} \mathrm{Ce}$ & ${ }^{141} \mathrm{Pr}$ & ${ }^{146} \mathrm{Nd}$ & ${ }^{152} \mathrm{Sm}$ & ${ }^{153} \mathbf{E u}$ & ${ }^{156} \mathrm{Gd}$ \\
\hline Deconsolidation acid & $<2.09 \mathrm{E}-5$ & $1.01 \mathrm{E}-4$ & $4.41 \mathrm{E}-6$ & $1.93 \mathrm{E}-5$ & $1.40 \mathrm{E}-5$ & $5.05 \mathrm{E}-6$ & 4.72E-6 & $1.13 \mathrm{E}-5$ & $5.54 \mathrm{E}-5$ & $8.76 \mathrm{E}-5$ \\
\hline Pre-burn leach 1 & $<2.53 \mathrm{E}-5$ & $4.84 \mathrm{E}-4$ & $4.06 \mathrm{E}-6$ & $5.75 \mathrm{E}-5$ & $6.16 \mathrm{E}-5$ & $8.17 \mathrm{E}-6$ & $6.55 \mathrm{E}-6$ & $2.65 \mathrm{E}-5$ & $1.27 \mathrm{E}-3$ & $2.48 \mathrm{E}-4$ \\
\hline Pre-burn leach 2 & $<4.00 \mathrm{E}-5$ & $1.27 \mathrm{E}-4$ & $4.85 \mathrm{E}-6$ & $8.89 \mathrm{E}-6$ & $1.31 \mathrm{E}-5$ & $4.16 \mathrm{E}-6$ & $4.28 \mathrm{E}-6$ & $<1.27 \mathrm{E}-5$ & $2.76 \mathrm{E}-5$ & $6.35 \mathrm{E}-5$ \\
\hline Post-burn particle leach 1 & $<2.45 \mathrm{E}-5$ & $6.21 \mathrm{E}-5$ & $5.50 \mathrm{E}-6$ & $2.00 \mathrm{E}-4$ & $1.68 \mathrm{E}-4$ & $2.68 \mathrm{E}-5$ & $2.05 \mathrm{E}-5$ & $5.75 \mathrm{E}-5$ & $3.01 \mathrm{E}-4$ & $8.65 \mathrm{E}-4$ \\
\hline Post-burn particle leach 2 & $<2.61 \mathrm{E}-5$ & $<3.31 \mathrm{E}-5$ & $2.23 \mathrm{E}-6$ & $1.14 \mathrm{E}-5$ & $1.26 \mathrm{E}-5$ & $3.01 \mathrm{E}-6$ & $2.94 \mathrm{E}-6$ & $<8.29 \mathrm{E}-6$ & $1.65 \mathrm{E}-5$ & $7.16 \mathrm{E}-5$ \\
\hline Total & & $7.74 \mathrm{E}-4$ & $2.10 \mathrm{E}-5$ & $2.97 \mathrm{E}-4$ & $2.69 \mathrm{E}-4$ & $4.72 \mathrm{E}-5$ & $3.90 \mathrm{E}-5$ & $9.54 \mathrm{E}-5$ & $1.67 \mathrm{E}-3$ & $1.34 \mathrm{E}-3$ \\
\hline Equivalent particle inventory ${ }^{c}$ & & 2.5 & 0.067 & 0.95 & 0.86 & 0.15 & 0.12 & 0.30 & 5.3 & 4.2 \\
\hline
\end{tabular}

${ }^{a}$ Compact inventory fractions are the measured grams of each stable isotope divided by the calculated compact inventory of that isotope one year after the end of the irradiation. Values that primarily contributed to the total for each isotope are highlighted. Numbers in gray are low compared to possible background. A less than value indicates the concentration in the leachate was below the minimum detectable limit and these values are not included in the totals.

${ }^{b}$ Equivalent particle inventory is the compact fraction times the average number of particles per compact (3176); a compact fraction of $3.15 \mathrm{E}-4$ is equivalent to one particle. 


\section{INDIVIDUAL PARTICLE GAMMA ANALYSIS}

Separation of the TRISO-coated particles from the compact matrix for individual survey of relative ${ }^{144} \mathrm{Ce}$ and ${ }^{137} \mathrm{Cs}$ inventory with the IMGA was not performed because no particles with defective or failed $\mathrm{SiC}$ or TRISO were expected. After particle burn-back and post-burn leaching, 43 particles were randomly selected for six-hour gamma counting. Figure 1 is a histogram of the measured ${ }^{110 \mathrm{~m}} \mathrm{Ag}$ activity in each particle, $\mathrm{A}_{\mathrm{i}}\left({ }^{110 \mathrm{~m}} \mathrm{Ag}\right)$, divided by an estimation of the calculated ${ }^{110 \mathrm{~m}} \mathrm{Ag}$ inventory for that particle if silver were fully-retained (a quantity that will be denoted as ${ }^{110 \mathrm{~m}} \mathrm{Ag} \mathrm{M} / \mathrm{C}$ and obtained with the equation in Figure 1). The calculated ${ }^{110 \mathrm{~m}} \mathrm{Ag}$ inventory in each particle was estimated from the average calculated inventory in a single particle $\mathrm{A}_{\text {calc }}\left({ }^{110 \mathrm{~m}} \mathrm{Ag}\right.$ ) multiplied by the ${ }^{137} \mathrm{Cs}$ activity in that particular particle normalized to the average in all measured particles to adjust for particle-to-particle variation in initial fissile content and burnup. The average calculated inventory in a single particle came from the calculated inventory in the compact one day after the end of the irradiation [Sterbentz 2014] divided by the average number of particles in an AGR-2 UCO compact (3176), which was determined by analyzing 20 compacts during pre-irradiation characterization [Hunn, Montgomery, and Pappano 2010a]. Figure 2 and Figure 3 show similarly-calculated $\mathrm{M} / \mathrm{C}$ inventory distributions for ${ }^{144} \mathrm{Ce}$ and ${ }^{154} \mathrm{Eu}$, respectively.

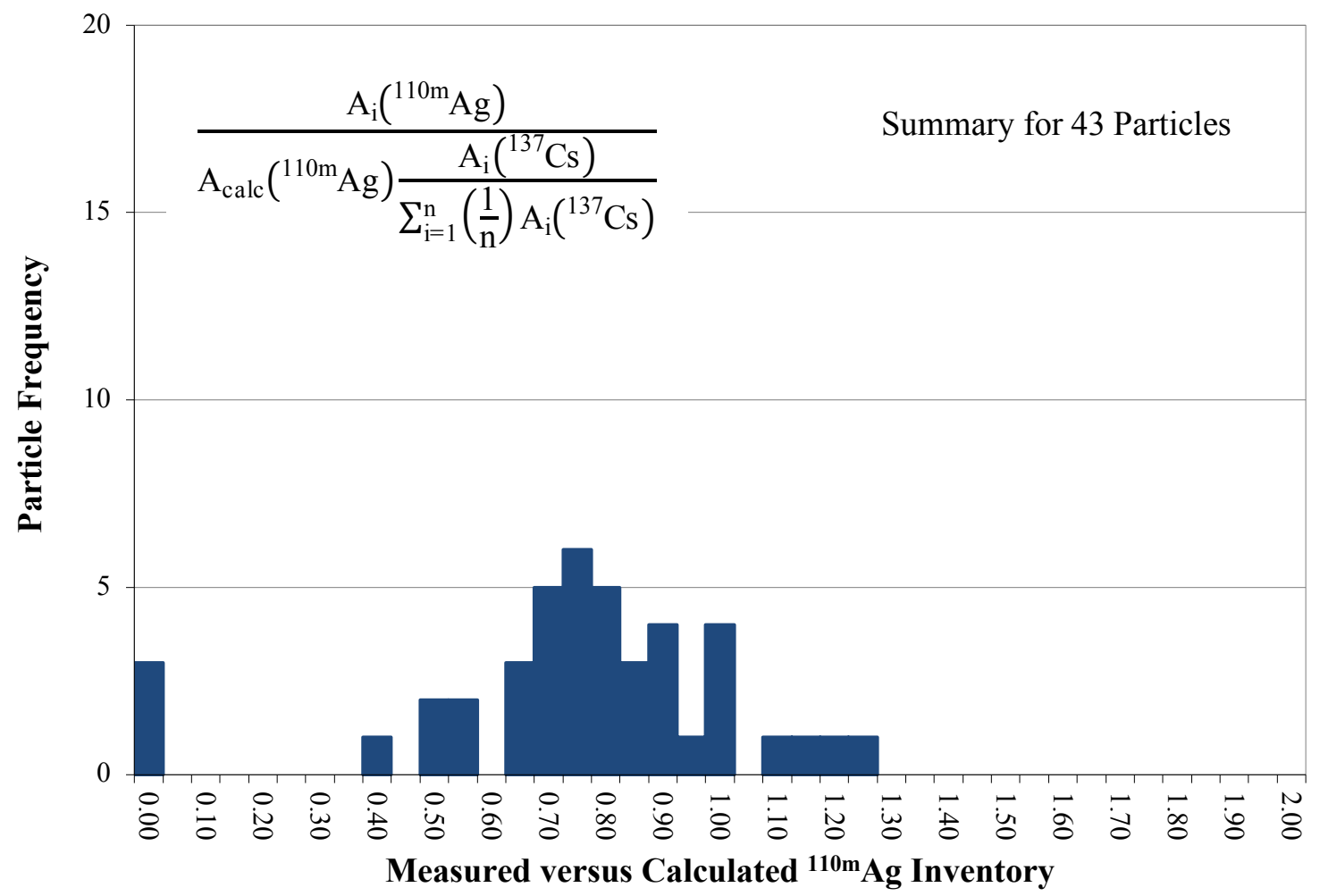

Figure 1. Ratio of ${ }^{110 \mathrm{~m}} \mathrm{Ag}$ retained in 43 particles versus the calculated inventory, adjusted for variation in fissionable material and burnup with the measured ${ }^{137} \mathrm{Cs}$ activity. Particles plotted as "zero" had a ${ }^{110 \mathrm{~m}} \mathrm{Ag}$ $\mathrm{M} / \mathrm{C} \lesssim \mathbf{3 3} \%$.

The ${ }^{110 \mathrm{~m}} \mathrm{Ag}$ distribution (Figure 1) showed a broad particle-to-particle variability in ${ }^{110 \mathrm{~m}} \mathrm{Ag} \mathrm{M} / \mathrm{C}$ ranging from essentially full retention to $<33 \%$ retention. This behavior has been observed in other AGR compacts [Demkowicz et al. 2015] and is conjectured to be primarily a function of the temperature history of each particle, which can vary several hundred degrees across the compact [Hawkes 2014]. Particles with different ${ }^{110 \mathrm{~m}} \mathrm{Ag} \mathrm{M} / \mathrm{C}$ values were selected for further analysis (Sections 4 and 5). 


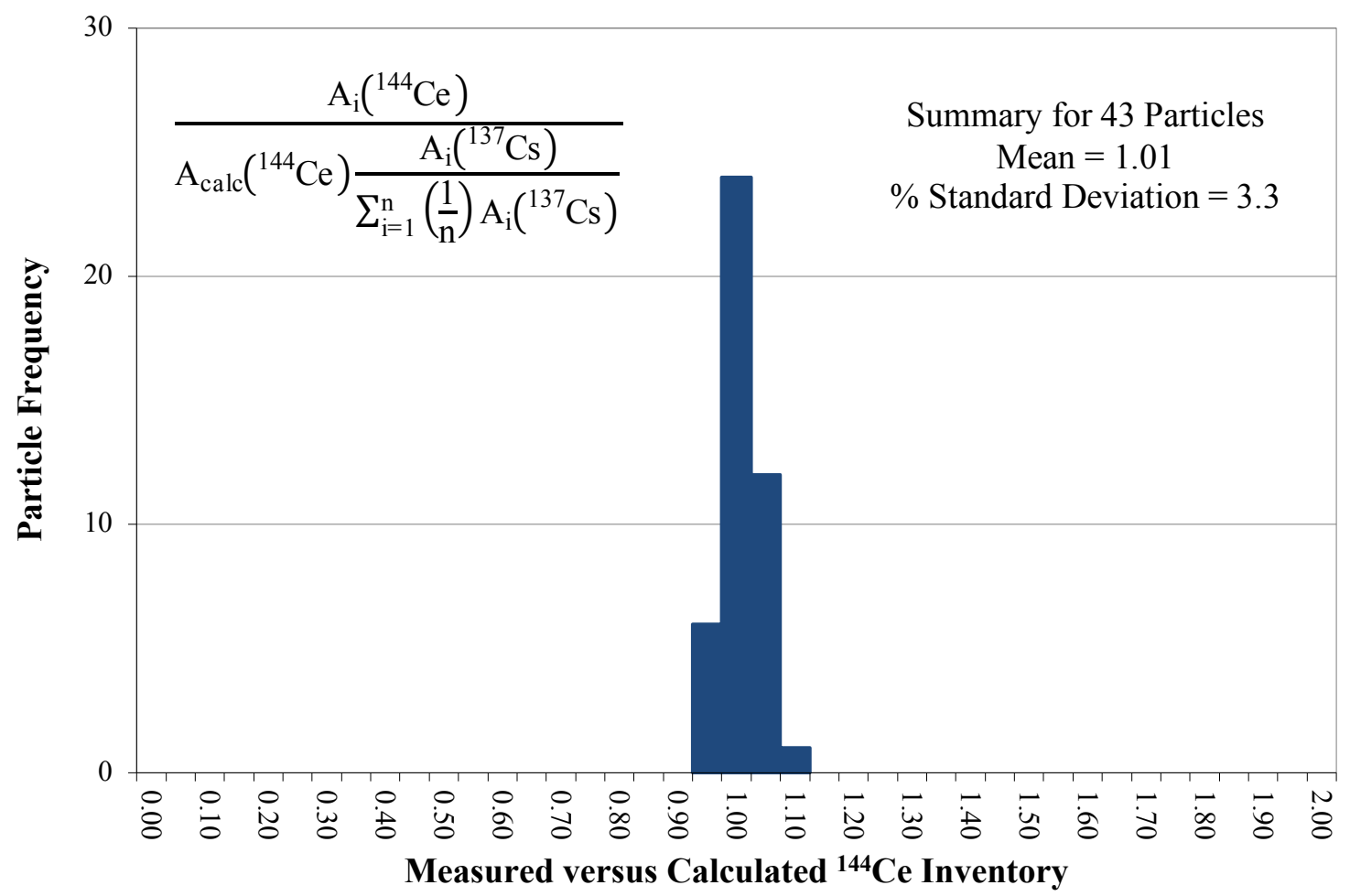

Figure 2. Ratio of ${ }^{144} \mathrm{Ce}$ retained in $\mathbf{4 3}$ particles versus the calculated inventory, adjusted for variation in fissionable material and burnup with the measured ${ }^{137} \mathrm{Cs}$ activity.

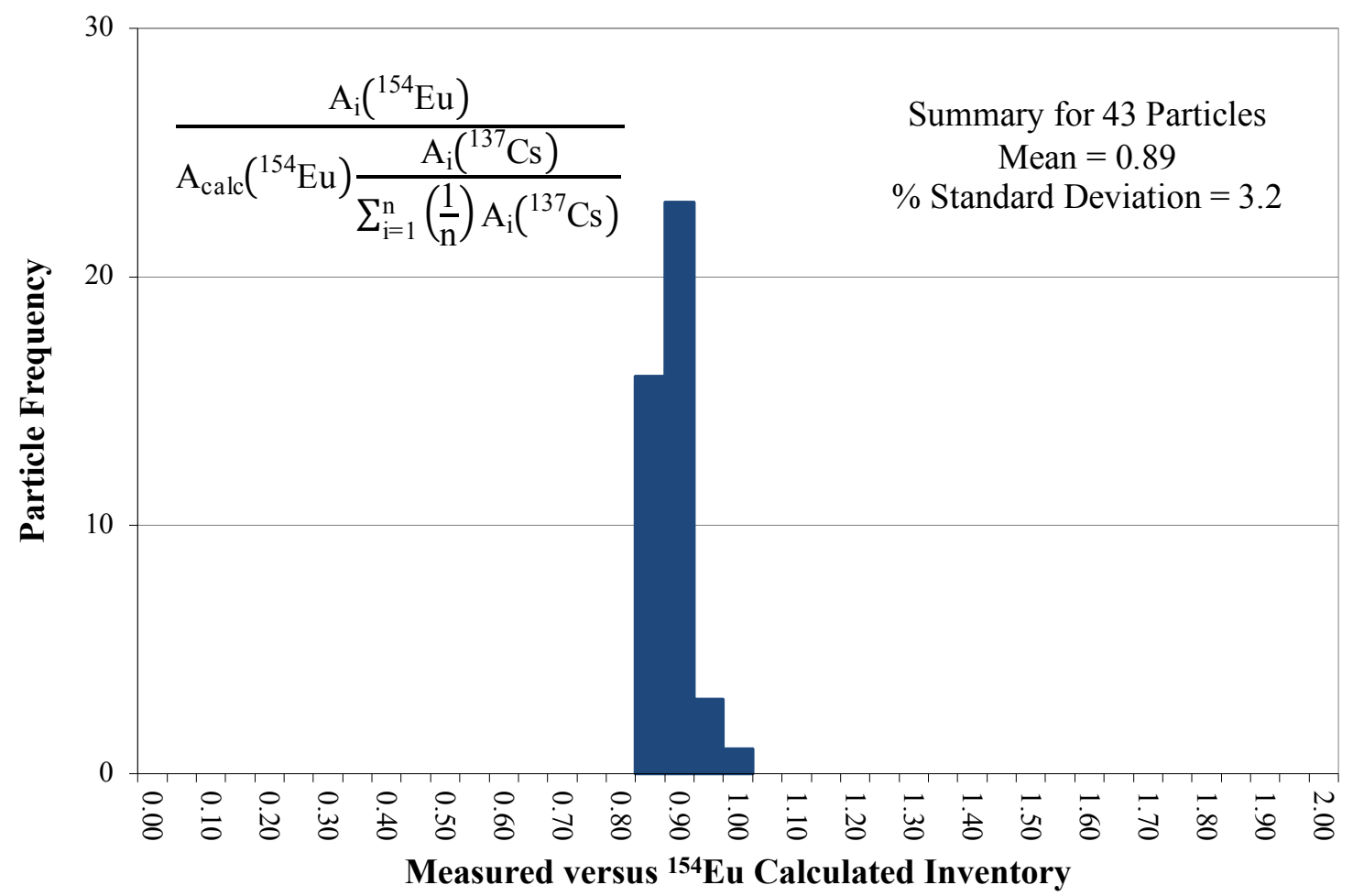

Figure 3. Ratio of ${ }^{154} \mathrm{Eu}$ retained in 43 particles versus the calculated inventory, adjusted for variation in fissionable material and burnup with the measured ${ }^{137} \mathrm{Cs}$ activity.

The ${ }^{144} \mathrm{Ce}$ and ${ }^{154} \mathrm{Eu}$ distributions (Figure 2 and Figure 3 ) were relatively narrow, which indicates good retention. The ${ }^{154} \mathrm{Eu}$ distribution was offset from unity (centered at ${ }^{154} \mathrm{Eu} \mathrm{M} / \mathrm{C}=0.89$ ) but this does not 
indicate that the average particle released fission products equivalent to the offset. It is known that there is a bias in the ${ }^{154} \mathrm{Eu}$ calculated inventory because of uncertainties in the input to the JMOCUP physics calculation [Sterbentz 2014]. Table 5 lists the biases observed in the AGR-1 experiment when the calculated values were compared to gamma scan data of the whole compacts with the INL Precision Gamma Scanner (PGS) [Harp et al. 2014]. The relatively-large offsets in the ${ }^{125} \mathrm{Sb}$ and ${ }^{154} \mathrm{Eu}$ measured-tocalculated ratios for Compact 6-4-2 are in the range of what was observed for AGR-1. The offset for ${ }^{106} \mathrm{Ru}$ measured-to-calculated ratio for Compact 6-4-2 was also noticeably offset above one but similar to what is being observed in IMGA measurement of particles from other AGR-2 compacts and this offset is expected to also be related to the physics calculations. Table 6 shows the IMGA data for each individual particle.

Table 5. Summary of results from 6-hour IMGA analysis of Compact 6-4-2 particles

\begin{tabular}{cccccccc}
\hline & $\begin{array}{c}\text { Average } \\
\text { Calculated } \\
\text { Istivity }\end{array}$ & \multicolumn{2}{c}{$\begin{array}{c}\text { Measured Activity } \\
(\mathrm{Bq} / \text { particle })\end{array}$} & \multicolumn{2}{c}{$\begin{array}{c}\text { Ratio of Measured versus } \\
\text { Average Calculated Activity }\end{array}$} & $\begin{array}{c}\text { Measured-to-Calculated Ratio } \\
\text { in AGR-1 Compact Activity }{ }^{d}\end{array}$ \\
\cline { 3 - 8 }$(\mathrm{Bq} /$ particle $)$ & mean & std. dev. & mean & std. dev. & mean & std. dev. \\
\hline${ }^{106} \mathrm{Ru}$ & $8.81 \mathrm{E}+6$ & $9.39 \mathrm{E}+6$ & $7.6 \%$ & 1.07 & 0.08 & 0.96 & 0.04 \\
${ }^{110 \mathrm{~m}} \mathrm{Ag}{ }^{e}$ & $2.30 \mathrm{E}+4$ & $1.73 \mathrm{E}+4-1.78 \mathrm{E}+4$ & $38-30 \%$ & $0.75-0.78$ & $0.29-0.23$ & not in reference \\
${ }^{125} \mathrm{Sb}$ & $2.63 \mathrm{E}+5$ & $1.94 \mathrm{E}+5$ & $6.4 \%$ & 0.74 & 0.05 & 0.70 & 0.04 \\
${ }^{134} \mathrm{Cs}$ & $2.84 \mathrm{E}+6$ & $2.82 \mathrm{E}+6$ & $7.5 \%$ & 0.99 & 0.07 & 0.97 & 0.05 \\
${ }^{137} \mathrm{Cs}$ & $4.00 \mathrm{E}+6$ & $4.12 \mathrm{E}+6$ & $5.8 \%$ & 1.03 & 0.06 & 0.99 & 0.03 \\
${ }^{144} \mathrm{Ce}$ & $4.09 \mathrm{E}+7$ & $4.13 \mathrm{E}+7$ & $5.6 \%$ & 1.01 & 0.06 & 1.00 & 0.04 \\
${ }^{154} \mathrm{Eu}$ & $1.15 \mathrm{E}+5$ & $1.02 \mathrm{E}+5$ & $7.9 \%$ & 0.89 & 0.07 & 0.83 & 0.04 \\
\hline
\end{tabular}

${ }^{a}$ Calculated activity for one day after end of irradiation.

${ }^{b}$ Measured activity decay-corrected to one day after end of irradiation.

${ }^{c}$ Not the same as $\mathrm{M} / \mathrm{C}$, which is also adjusted for variation in fissionable material and burnup.

${ }^{d}$ Summary results from gamma scanning of whole AGR-1 compacts [Demkowicz et al. 2015, table 14].

${ }^{e}$ Values for ${ }^{110 \mathrm{~m}} \mathrm{Ag}$ are presented as a range where particles below the detection limit were treated as ranging from a minimum value of zero to a maximum value of the detection limit.

Table 6. Results of 6-hour gamma scanning of 43 randomly-selected (RS) particles showing measured activity (Bq/particle decay-corrected to $\mathrm{EOL}+1$ day)

\begin{tabular}{|c|c|c|c|c|c|c|c|}
\hline Particle & ${ }^{106} \mathrm{Ru}$ & ${ }^{110 m} \mathrm{Ag}^{a}$ & ${ }^{125} \mathrm{Sb}$ & ${ }^{134} \mathrm{Cs}$ & ${ }^{137} \mathrm{Cs}$ & ${ }^{144} \mathrm{Ce}$ & ${ }^{154} \mathrm{Eu}$ \\
\hline 642-RS01 & $9.27 \mathrm{E}+6$ & $2.86 \mathrm{E}+4$ & $1.96 \mathrm{E}+5$ & $2.96 \mathrm{E}+6$ & $4.25 \mathrm{E}+6$ & $3.98 \mathrm{E}+7$ & $1.10 \mathrm{E}+5$ \\
\hline 642-RS02 & $9.42 \mathrm{E}+6$ & $1.87 \mathrm{E}+4$ & $2.01 \mathrm{E}+5$ & $2.83 \mathrm{E}+6$ & $4.23 \mathrm{E}+6$ & $4.29 \mathrm{E}+7$ & $1.02 \mathrm{E}+5$ \\
\hline 642-RS03 & $8.63 \mathrm{E}+6$ & $1.98 \mathrm{E}+4$ & $1.83 \mathrm{E}+5$ & $2.64 \mathrm{E}+6$ & $3.93 \mathrm{E}+6$ & $3.98 \mathrm{E}+7$ & $9.57 \mathrm{E}+4$ \\
\hline 642-RS04 & $8.70 \mathrm{E}+6$ & $1.10 \mathrm{E}+4$ & $1.79 \mathrm{E}+5$ & $2.61 \mathrm{E}+6$ & $3.87 \mathrm{E}+6$ & $3.69 \mathrm{E}+7$ & $9.91 \mathrm{E}+4$ \\
\hline 642-RS05 & $9.20 \mathrm{E}+6$ & $1.94 \mathrm{E}+4$ & $1.80 \mathrm{E}+5$ & $2.55 \mathrm{E}+6$ & $3.87 \mathrm{E}+6$ & $3.88 \mathrm{E}+7$ & $9.45 \mathrm{E}+4$ \\
\hline 642-RS06 & $1.02 \mathrm{E}+7$ & $1.75 \mathrm{E}+4$ & $2.10 \mathrm{E}+5$ & $3.08 \mathrm{E}+6$ & $4.42 \mathrm{E}+6$ & $4.40 \mathrm{E}+7$ & $1.10 \mathrm{E}+5$ \\
\hline 642-RS07 & $8.52 \mathrm{E}+6$ & $1.59 \mathrm{E}+4$ & $1.74 \mathrm{E}+5$ & $2.54 \mathrm{E}+6$ & $3.75 \mathrm{E}+6$ & $3.88 \mathrm{E}+7$ & $9.22 \mathrm{E}+4$ \\
\hline 642-RS08 & $9.00 \mathrm{E}+6$ & $1.65 \mathrm{E}+4$ & $1.89 \mathrm{E}+5$ & $2.69 \mathrm{E}+6$ & $4.02 \mathrm{E}+6$ & $4.12 \mathrm{E}+7$ & $9.71 \mathrm{E}+4$ \\
\hline 642-RS09 & $9.23 \mathrm{E}+6$ & $1.47 \mathrm{E}+4$ & $1.94 \mathrm{E}+5$ & $2.67 \mathrm{E}+6$ & $4.12 \mathrm{E}+6$ & $4.10 \mathrm{E}+7$ & $9.82 \mathrm{E}+4$ \\
\hline 642-RS10 & $9.79 \mathrm{E}+6$ & $2.45 \mathrm{E}+4$ & $2.08 \mathrm{E}+5$ & $3.05 \mathrm{E}+6$ & $4.40 \mathrm{E}+6$ & $4.27 \mathrm{E}+7$ & $1.11 \mathrm{E}+5$ \\
\hline 642-RS11 & $9.25 \mathrm{E}+6$ & $1.63 \mathrm{E}+4$ & $1.96 \mathrm{E}+5$ & $2.85 \mathrm{E}+6$ & $4.22 \mathrm{E}+6$ & $4.26 \mathrm{E}+7$ & $1.01 \mathrm{E}+5$ \\
\hline 642-RS12 & $9.70 \mathrm{E}+6$ & $1.55 \mathrm{E}+4$ & $2.00 \mathrm{E}+5$ & $2.90 \mathrm{E}+6$ & $4.18 \mathrm{E}+6$ & $4.24 \mathrm{E}+7$ & $1.03 \mathrm{E}+5$ \\
\hline 642-RS13 & $1.06 \mathrm{E}+7$ & $2.41 \mathrm{E}+4$ & $2.08 \mathrm{E}+5$ & $3.15 \mathrm{E}+6$ & $4.39 \mathrm{E}+6$ & $4.36 \mathrm{E}+7$ & $1.15 \mathrm{E}+5$ \\
\hline 642-RS14 & $9.19 \mathrm{E}+6$ & $<7.60 \mathrm{E}+3$ & $1.92 \mathrm{E}+5$ & $2.63 \mathrm{E}+6$ & $4.00 \mathrm{E}+6$ & $4.11 \mathrm{E}+7$ & $9.48 \mathrm{E}+4$ \\
\hline 642-RS15 & $9.37 \mathrm{E}+6$ & $2.55 \mathrm{E}+4$ & $1.98 \mathrm{E}+5$ & $2.83 \mathrm{E}+6$ & $4.14 \mathrm{E}+6$ & $4.26 \mathrm{E}+7$ & $9.80 \mathrm{E}+4$ \\
\hline 642-RS16 & $9.61 \mathrm{E}+6$ & $1.87 \mathrm{E}+4$ & $2.02 \mathrm{E}+5$ & $2.75 \mathrm{E}+6$ & $4.23 \mathrm{E}+6$ & $4.15 \mathrm{E}+7$ & $1.02 \mathrm{E}+5$ \\
\hline 642-RS17 & $8.36 \mathrm{E}+6$ & $<7.52 \mathrm{E}+3$ & $1.72 \mathrm{E}+5$ & $2.46 \mathrm{E}+6$ & $3.69 \mathrm{E}+6$ & $3.81 \mathrm{E}+7$ & $8.86 \mathrm{E}+4$ \\
\hline
\end{tabular}


Table 6 (continued). Results of 6-hour gamma scanning of 43 randomly-selected (RS) particles showing measured activity (Bq/particle decay-corrected to EOL+1 day)

\begin{tabular}{|c|c|c|c|c|c|c|c|}
\hline Particle & ${ }^{106} \mathrm{Ru}$ & ${ }^{110 \mathrm{~m}} \mathrm{Ag}^{a}$ & ${ }^{125} \mathrm{Sb}$ & ${ }^{134} \mathrm{Cs}$ & ${ }^{137} \mathrm{Cs}$ & ${ }^{144} \mathrm{Ce}$ & ${ }^{154} \mathrm{Eu}$ \\
\hline 642-RS18 & $8.91 \mathrm{E}+6$ & $1.79 \mathrm{E}+4$ & $1.82 \mathrm{E}+5$ & $2.73 \mathrm{E}+6$ & $3.97 \mathrm{E}+6$ & $4.01 \mathrm{E}+7$ & $9.77 \mathrm{E}+4$ \\
\hline 642-RS19 & $9.14 \mathrm{E}+6$ & $1.64 \mathrm{E}+4$ & $1.88 \mathrm{E}+5$ & $2.70 \mathrm{E}+6$ & $3.91 \mathrm{E}+6$ & $4.08 \mathrm{E}+7$ & $9.59 \mathrm{E}+4$ \\
\hline 642-RS20 & $8.44 \mathrm{E}+6$ & $1.35 \mathrm{E}+4$ & $1.81 \mathrm{E}+5$ & $2.59 \mathrm{E}+6$ & $3.83 \mathrm{E}+6$ & $3.78 \mathrm{E}+7$ & $9.60 \mathrm{E}+4$ \\
\hline 642-RS21 & $8.72 E+6$ & $1.75 \mathrm{E}+4$ & $1.78 \mathrm{E}+5$ & $2.77 \mathrm{E}+6$ & $3.87 \mathrm{E}+6$ & $3.75 \mathrm{E}+7$ & $9.91 \mathrm{E}+4$ \\
\hline 642-RS22 & $9.16 \mathrm{E}+6$ & $1.86 \mathrm{E}+4$ & $1.91 \mathrm{E}+5$ & $2.78 \mathrm{E}+6$ & $4.05 \mathrm{E}+6$ & $4.19 \mathrm{E}+7$ & $9.78 \mathrm{E}+4$ \\
\hline 642-RS23 & $9.48 \mathrm{E}+6$ & $2.96 \mathrm{E}+4$ & $1.96 \mathrm{E}+5$ & $3.00 \mathrm{E}+6$ & $4.22 \mathrm{E}+6$ & $4.15 \mathrm{E}+7$ & $1.06 \mathrm{E}+5$ \\
\hline 642-RS24 & $8.84 \mathrm{E}+6$ & $1.63 \mathrm{E}+4$ & $1.86 \mathrm{E}+5$ & $2.58 \mathrm{E}+6$ & $3.78 \mathrm{E}+6$ & $3.96 \mathrm{E}+7$ & $9.32 \mathrm{E}+4$ \\
\hline 642-RS25 & $1.08 \mathrm{E}+7$ & $2.50 \mathrm{E}+4$ & $2.12 \mathrm{E}+5$ & $3.21 \mathrm{E}+6$ & $4.50 \mathrm{E}+6$ & $4.26 \mathrm{E}+7$ & $1.21 \mathrm{E}+5$ \\
\hline 642-RS26 & $9.78 \mathrm{E}+6$ & $<7.41 \mathrm{E}+3$ & $2.03 \mathrm{E}+5$ & $2.92 \mathrm{E}+6$ & $4.27 \mathrm{E}+6$ & $4.30 \mathrm{E}+7$ & $1.04 \mathrm{E}+5$ \\
\hline 642-RS27 & $8.58 \mathrm{E}+6$ & $2.14 \mathrm{E}+4$ & $1.80 \mathrm{E}+5$ & $2.62 \mathrm{E}+6$ & $3.82 \mathrm{E}+6$ & $3.82 \mathrm{E}+7$ & $9.28 \mathrm{E}+4$ \\
\hline $642-\mathrm{RS} 28^{b}$ & $1.56 \mathrm{E}+7$ & $1.23 \mathrm{E}+4$ & $2.99 \mathrm{E}+5$ & $3.65 \mathrm{E}+6$ & $5.24 \mathrm{E}+6$ & $6.61 \mathrm{E}+7$ & $1.52 \mathrm{E}+5$ \\
\hline 642-RS29 & $9.70 \mathrm{E}+6$ & $2.15 \mathrm{E}+4$ & $2.02 \mathrm{E}+5$ & $2.99 \mathrm{E}+6$ & $4.39 \mathrm{E}+6$ & $4.40 \mathrm{E}+7$ & $1.07 \mathrm{E}+5$ \\
\hline 642-RS30 & $9.54 \mathrm{E}+6$ & $2.08 \mathrm{E}+4$ & $1.98 \mathrm{E}+5$ & $2.91 \mathrm{E}+6$ & $4.27 \mathrm{E}+6$ & $4.29 \mathrm{E}+7$ & $1.04 \mathrm{E}+5$ \\
\hline 642-RS31 & $1.00 \mathrm{E}+7$ & $1.31 \mathrm{E}+4$ & $2.12 \mathrm{E}+5$ & $3.17 \mathrm{E}+6$ & $4.48 \mathrm{E}+6$ & $4.38 \mathrm{E}+7$ & $1.12 \mathrm{E}+5$ \\
\hline 642-RS32 & $1.12 \mathrm{E}+7$ & $2.48 \mathrm{E}+4$ & $2.23 \mathrm{E}+5$ & $3.43 \mathrm{E}+6$ & $4.74 \mathrm{E}+6$ & $4.41 \mathrm{E}+7$ & $1.29 \mathrm{E}+5$ \\
\hline 642-RS33 & $1.01 \mathrm{E}+7$ & $1.72 \mathrm{E}+4$ & $2.07 \mathrm{E}+5$ & $3.07 \mathrm{E}+6$ & $4.31 \mathrm{E}+6$ & $4.28 \mathrm{E}+7$ & $1.10 \mathrm{E}+5$ \\
\hline 642-RS34 & $9.97 \mathrm{E}+6$ & $2.61 \mathrm{E}+4$ & $2.02 \mathrm{E}+5$ & $2.75 \mathrm{E}+6$ & $4.15 \mathrm{E}+6$ & $4.35 \mathrm{E}+7$ & $9.86 \mathrm{E}+4$ \\
\hline 642-RS35 & $9.21 \mathrm{E}+6$ & $2.07 \mathrm{E}+4$ & $1.93 \mathrm{E}+5$ & $2.95 \mathrm{E}+6$ & $4.29 \mathrm{E}+6$ & $4.25 \mathrm{E}+7$ & $1.06 \mathrm{E}+5$ \\
\hline 642-RS36 & $9.93 \mathrm{E}+6$ & $1.96 \mathrm{E}+4$ & $1.97 \mathrm{E}+5$ & $2.68 \mathrm{E}+6$ & $4.00 \mathrm{E}+6$ & $4.16 \mathrm{E}+7$ & $9.69 \mathrm{E}+4$ \\
\hline 642-RS38 & $1.13 \mathrm{E}+7$ & $9.70 \mathrm{E}+3$ & $2.22 \mathrm{E}+5$ & $3.00 \mathrm{E}+6$ & $4.39 \mathrm{E}+6$ & $4.78 \mathrm{E}+7$ & $1.06 \mathrm{E}+5$ \\
\hline 642-RS39 & $8.97 \mathrm{E}+6$ & $1.30 \mathrm{E}+4$ & $1.86 \mathrm{E}+5$ & $2.82 \mathrm{E}+6$ & $4.04 \mathrm{E}+6$ & $3.97 \mathrm{E}+7$ & $1.01 \mathrm{E}+5$ \\
\hline 642-RS40 & $8.88 \mathrm{E}+6$ & $1.62 \mathrm{E}+4$ & $1.83 \mathrm{E}+5$ & $2.65 \mathrm{E}+6$ & $3.91 \mathrm{E}+6$ & $3.85 \mathrm{E}+7$ & $9.76 \mathrm{E}+4$ \\
\hline 642-RS41 & $8.89 \mathrm{E}+6$ & $1.17 \mathrm{E}+4$ & $1.85 \mathrm{E}+5$ & $2.58 \mathrm{E}+6$ & $3.87 \mathrm{E}+6$ & $3.99 \mathrm{E}+7$ & $9.31 \mathrm{E}+4$ \\
\hline 642-RS42 & $9.80 \mathrm{E}+6$ & $1.62 \mathrm{E}+4$ & $2.03 \mathrm{E}+5$ & $2.85 \mathrm{E}+6$ & $4.21 \mathrm{E}+6$ & $4.39 \mathrm{E}+7$ & $1.01 \mathrm{E}+5$ \\
\hline 642-RS43 & $8.55 \mathrm{E}+6$ & $1.54 \mathrm{E}+4$ & $1.87 \mathrm{E}+5$ & $2.78 \mathrm{E}+6$ & $3.98 \mathrm{E}+6$ & $3.86 \mathrm{E}+7$ & $1.00 \mathrm{E}+5$ \\
\hline 642-RS44 & $8.40 \mathrm{E}+6$ & $1.63 \mathrm{E}+4$ & $1.78 \mathrm{E}+5$ & $2.67 \mathrm{E}+6$ & $3.84 \mathrm{E}+6$ & $3.85 \mathrm{E}+7$ & $9.55 \mathrm{E}+4$ \\
\hline 642-RS45 & $9.36 \mathrm{E}+6$ & $2.00 \mathrm{E}+4$ & $2.00 \mathrm{E}+5$ & $2.99 \mathrm{E}+6$ & $4.29 \mathrm{E}+6$ & $4.15 \mathrm{E}+7$ & $1.07 \mathrm{E}+5$ \\
\hline Maximum & $1.13 \mathrm{E}+7$ & $2.96 \mathrm{E}+4$ & $2.23 \mathrm{E}+5$ & $3.43 \mathrm{E}+6$ & $4.74 \mathrm{E}+6$ & $4.78 \mathrm{E}+7$ & $1.29 \mathrm{E}+5$ \\
\hline Minimum & $8.36 \mathrm{E}+6$ & $<7.41 \mathrm{E}+3$ & $1.72 \mathrm{E}+5$ & $2.46 \mathrm{E}+6$ & $3.69 \mathrm{E}+6$ & $3.69 \mathrm{E}+7$ & $8.86 \mathrm{E}+4$ \\
\hline Mean & $9.39 \mathrm{E}+6$ & $1.73-1.78 \mathrm{E}+4$ & $1.94 \mathrm{E}+5$ & $2.82 \mathrm{E}+6$ & $4.12 \mathrm{E}+6$ & $4.13 \mathrm{E}+7$ & $1.02 \mathrm{E}+5$ \\
\hline Std. Dev. & $7.6 \%$ & $38-30 \%$ & $6.4 \%$ & $7.5 \%$ & $5.8 \%$ & $5.6 \%$ & $7.9 \%$ \\
\hline
\end{tabular}

${ }^{a}$ Less than values indicate the ${ }^{110 \mathrm{~m}} \mathrm{Ag}$ activity was below the detection limit. Summary values for ${ }^{110 \mathrm{~m}} \mathrm{Ag}$ are presented as a range where particles below the detection limit were treated as ranging from a minimum value of zero to a maximum value of the detection limit.

${ }^{b}$ Particle 642-RS28 had an unusually-high inventory and was not included in the mean. 


\section{MATERIALOGRAPHY}

The six-hour IMGA measurement data in Table 6 were used to select particles for microstructural analyses from various regions of the ${ }^{110 \mathrm{~m}} \mathrm{Ag}$ distribution (Figure 1), with a secondary criterion of wanting other isotope inventories in these particles to be generally close to average. Table 7 lists the particles selected for materialography. The measured versus calculated inventory $(\mathrm{M} / \mathrm{C})$ values in the table were calculated with the same method used for Figure 1-Figure 3. The measured versus average inventory values were calculated similar to the $\mathrm{M} / \mathrm{C}$ values, except the offset in the calculated activity was mostly removed by replacing the calculated activity for each isotope in the equation with the measured average activity for the 43-particle data set, for example

$$
\frac{\mathrm{A}_{\mathrm{i}}\left({ }^{154} \mathrm{Eu}\right)}{\sum_{\mathrm{i}=1}^{\mathrm{n}}\left(\frac{1}{\mathrm{n}}\right) \mathrm{A}_{\mathrm{i}}\left({ }^{154} \mathrm{Eu}\right) \frac{\mathrm{A}_{\mathrm{i}}\left({ }^{137} \mathrm{Cs}\right)}{\sum_{\mathrm{i}=1}^{\mathrm{n}}\left(\frac{1}{\mathrm{n}}\right) \mathrm{A}_{\mathrm{i}}\left({ }^{137} \mathrm{Cs}\right)}}
$$

This shifted the M/C distribution to be essentially-centered around unity, making it easier to survey the results with respect to the average.

Table 7. Particles selected for materialography

\begin{tabular}{|c|c|c|c|c|c|c|c|}
\hline Particl & ${ }_{106} R_{u}$ & $110 \mathrm{~m}$ & $125 \mathrm{Ch}$ & & $37 \mathrm{C}$ & $44 \pi$ & $154 \mathrm{~F}$ \\
\hline 642-RS26 & 1.07 & $<0.31$ & 074 & 000 & $10 ?$ & 102 & 088 \\
\hline 642-RS18 & 1.05 & 0.81 & 0.72 & 1.00 & 102 & 1.02 & 0.89 \\
\hline 642-RS44 & 1.02 & 0.76 & 0.72 & 1.01 & 1.03 & 1.01 & 0.89 \\
\hline 642-RS23 & 1.05 & 1.26 & 0.73 & 1.03 & 1.05 & 0.99 & 0.90 \\
\hline 642-RS27 & 1.05 & 1.00 & 0.73 & 1.00 & 1.03 & 1.01 & 0.87 \\
\hline
\end{tabular}

\begin{tabular}{|c|c|c|c|c|c|c|c|}
\hline \multicolumn{8}{|c|}{ Measured versus average inventory ${ }^{b}$} \\
\hline Particle & ${ }^{106} \mathbf{R u}$ & ${ }^{110 \mathrm{~m}} \mathrm{Ag}^{c}$ & ${ }^{125} \mathrm{Sb}$ & ${ }^{134} \mathrm{Cs}$ & ${ }^{137} \mathrm{Cs}$ & ${ }^{144} \mathrm{Ce}$ & ${ }^{154} \mathbf{E u}$ \\
\hline 642-RS26 & 1.00 & $<0.38$ & 1.01 & 1.00 & 0.99 & 1.01 & 0.99 \\
\hline 642-RS18 & 0.99 & 1.00 & 0.97 & 1.00 & 0.99 & 1.01 & 1.00 \\
\hline 642-RS44 & 0.96 & 0.94 & 0.98 & 1.02 & 1.00 & 1.00 & 1.01 \\
\hline 642-RS23 & 0.99 & 1.55 & 0.99 & 1.04 & 1.02 & 0.98 & 1.01 \\
\hline 642-RS27 & 0.99 & 1.24 & 1.00 & 1.00 & 1.00 & 1.00 & 0.98 \\
\hline
\end{tabular}

${ }^{a} \mathrm{M} / \mathrm{C}$ values were adjusted for fissile material and burnup using the normalized ${ }^{137} \mathrm{Cs}$ activity, except for ${ }^{137} \mathrm{Cs}$, which used the normalized ${ }^{144} \mathrm{Ce}$ activity.

${ }^{b}$ Measured versus average activity inventory values were adjusted for fissile material and burnup using the normalized ${ }^{137} \mathrm{Cs}$ activity, except for ${ }^{137} \mathrm{Cs}$, which used the normalized ${ }^{144} \mathrm{Ce}$ activity.

${ }^{c}$ Less than values indicate the ${ }^{110 \mathrm{~m}} \mathrm{Ag}$ activity was below the detection limit.

\subsection{OPTICAL MICROSCOPY}

Particles were mounted and polished to near midplane using the methods and equipment developed for AGR-1 PIE [Hunn et al. 2013]. Copied from [Hunn et al. 2018] for easy comparison to the irradiated images, Figure 4 shows two bright-field reflected-light optical micrographs of an as-fabricated AGR-2 UCO TRISO particle cross section near midplane. The UCO kernel shows the typical mixture of uranium carbide (white regions) and uranium oxide (gray regions) in the center of the kernel, surrounded by a uranium oxide rind and a uranium carbide skin at the surface. The lower-density buffer layer appears darker (less reflection) than the inner pyrocarbon (IPyC) and outer pyrocarbon (OPyC) layers. The $\mathrm{IPyC} / \mathrm{SiC}$ interface shows evidence of the stitching that occurs when the $\mathrm{SiC}$ deposition infiltrates the open porosity of the IPyC. The character of the $\mathrm{SiC} / \mathrm{OPyC}$ interface is different because the SiC surface is non-porous, however the OPyC does closely replicate the granular surface of the SiC. Note that irradiated images will not have an $\mathrm{OPyC}$, which was burned off prior to IMGA and microstructural analysis. 


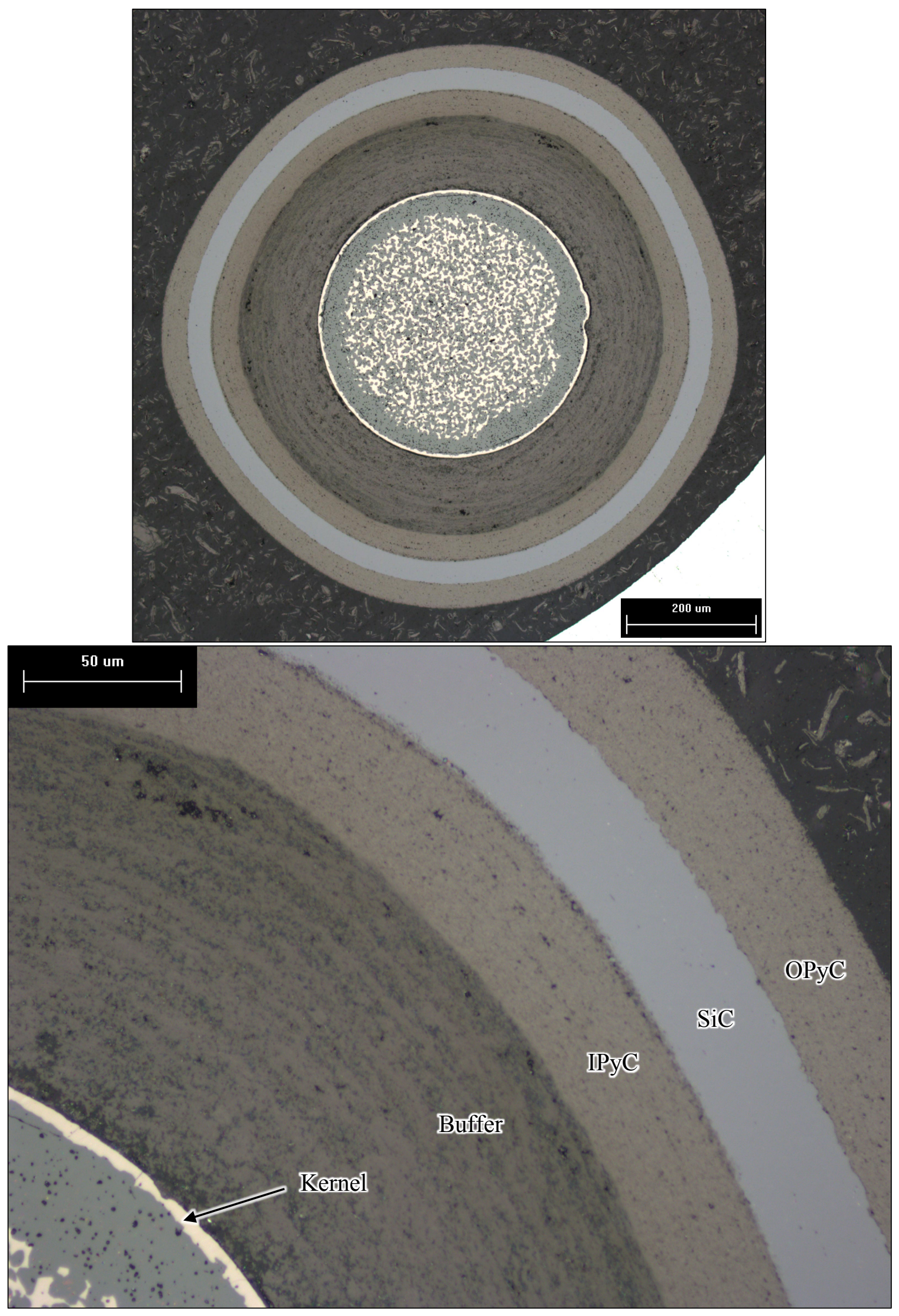

Figure 4. As-fabricated AGR-2 UCO TRISO (LEU09). 
Figure 5-Figure 9 are optical micrographs of the particle cross sections. Material with a uniform gray appearance in the gap between the buffer and IPyC is epoxy added under vacuum to backfill this space after it was exposed during grinding. Places where the gap regions appear black were not filled with epoxy. Similarly, revealed pores in the kernel often appear black. The regions that were not filled with epoxy did not adversely affect the polish quality to any significant degree, but they did have a tendency to hold residue from the oil used for lubrication during polishing and this oil residue sometimes stained the surface as the cleaning alcohol evaporated. These stains appear as darkened areas in the images.

The five particles shown in Figure 5-Figure 9 did not show any fractured buffer. A gap between the buffer and IPyC formed as the buffer shrinkage caused it to pull away from the IPyC, leaving fragments of the outermost buffer material still attached to the inside of the IPyC. Kernel swelling was symmetric and there was a reaction zone evident in the buffer immediately adjacent to the kernel, as discussed in the AGR-2 UCO Compact 5-4-2 report [Hunn et al. 2018]. Particle 642-RS27 (Figure 9) showed some highly-reflective material on the $\mathrm{SiC}$ that was apparently surface debris because it was not observed after cleaning in preparation for SEM. It is interesting that the cross section of Particle 642-RS27 revealed fewer large fission gas bubbles and the bubble distribution was less symmetric than the other particles. If this particle were located near the end of the compact, which was itself at the very top of the irradiation test train (Capsule 6, Level 4), it may have experienced a lower temperature and a more severe temperature gradient. This would be consistent with the kernel microstructure and the fact that this particle retained more silver.

To obtain better statistics on the buffer and kernel behavior, a single materialographic mount of randomly-selected particles was prepared. Polish quality was low on this mount due to scratches from debris, but the cross sections were sufficient to poll the kernel and buffer behavior in 43 of the 45 particles in the mount. Figure 10 is a compilation of individual images of each particle in the mount. Buffer fracture was obvious in 11 of the 43 analyzed particles and an additional 2 particles had cracks that may be early stages of buffer fracture. 

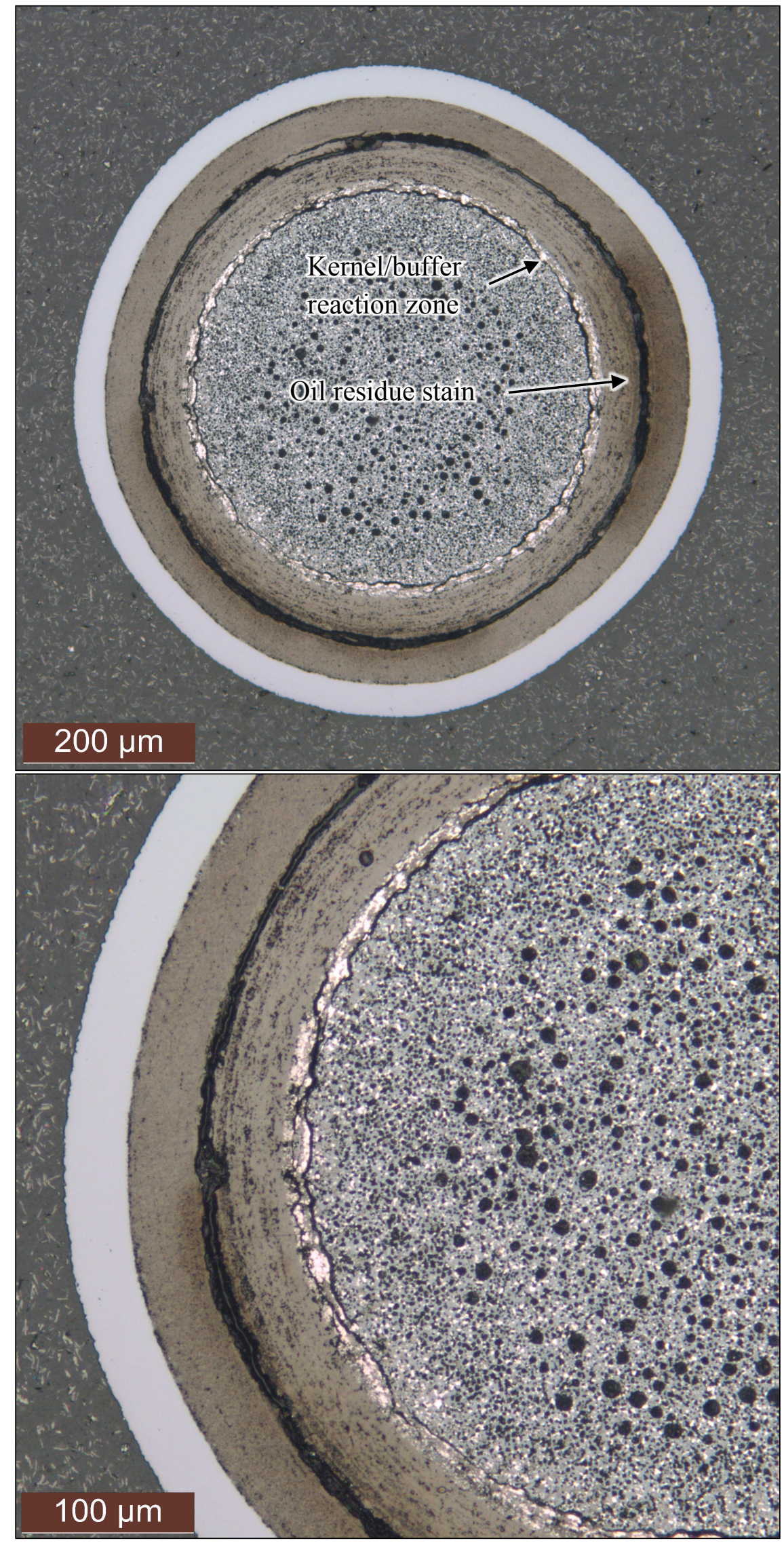

Figure 5. Particle 642-RS26 near midplane. 

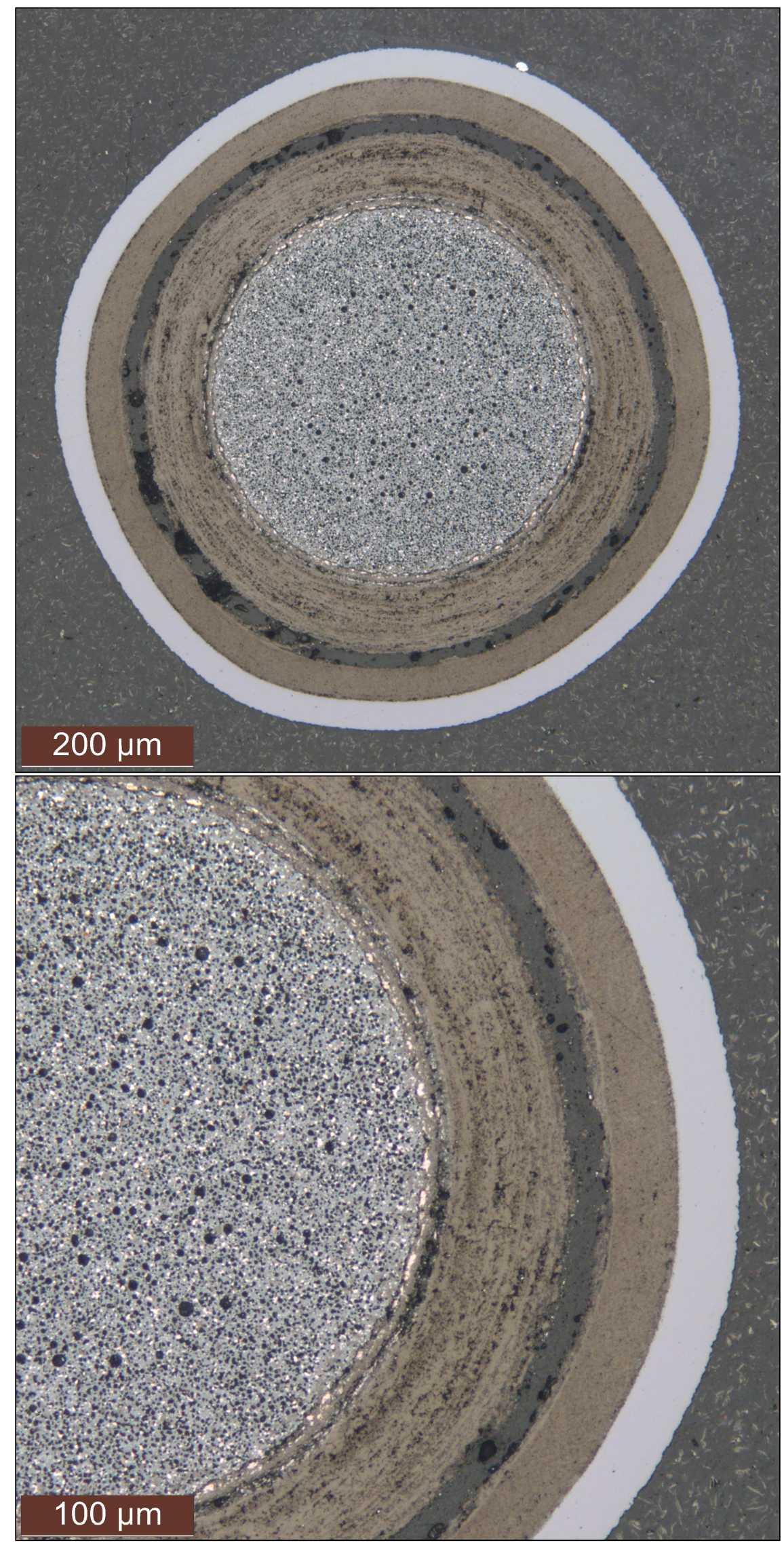

Figure 6. Particle 642-RS18 near midplane. 


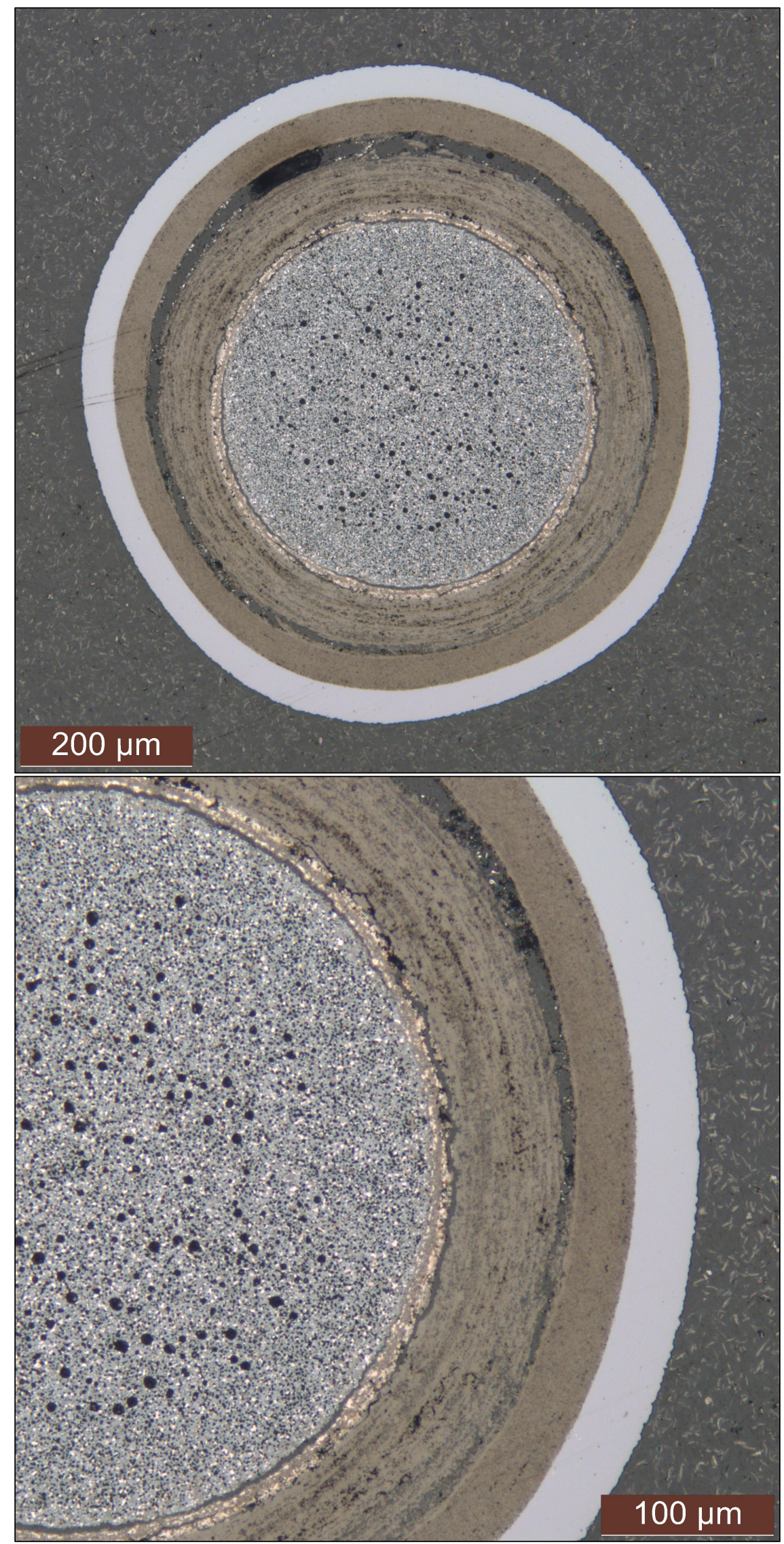

Figure 7. Particle 642-RS44 near midplane. 

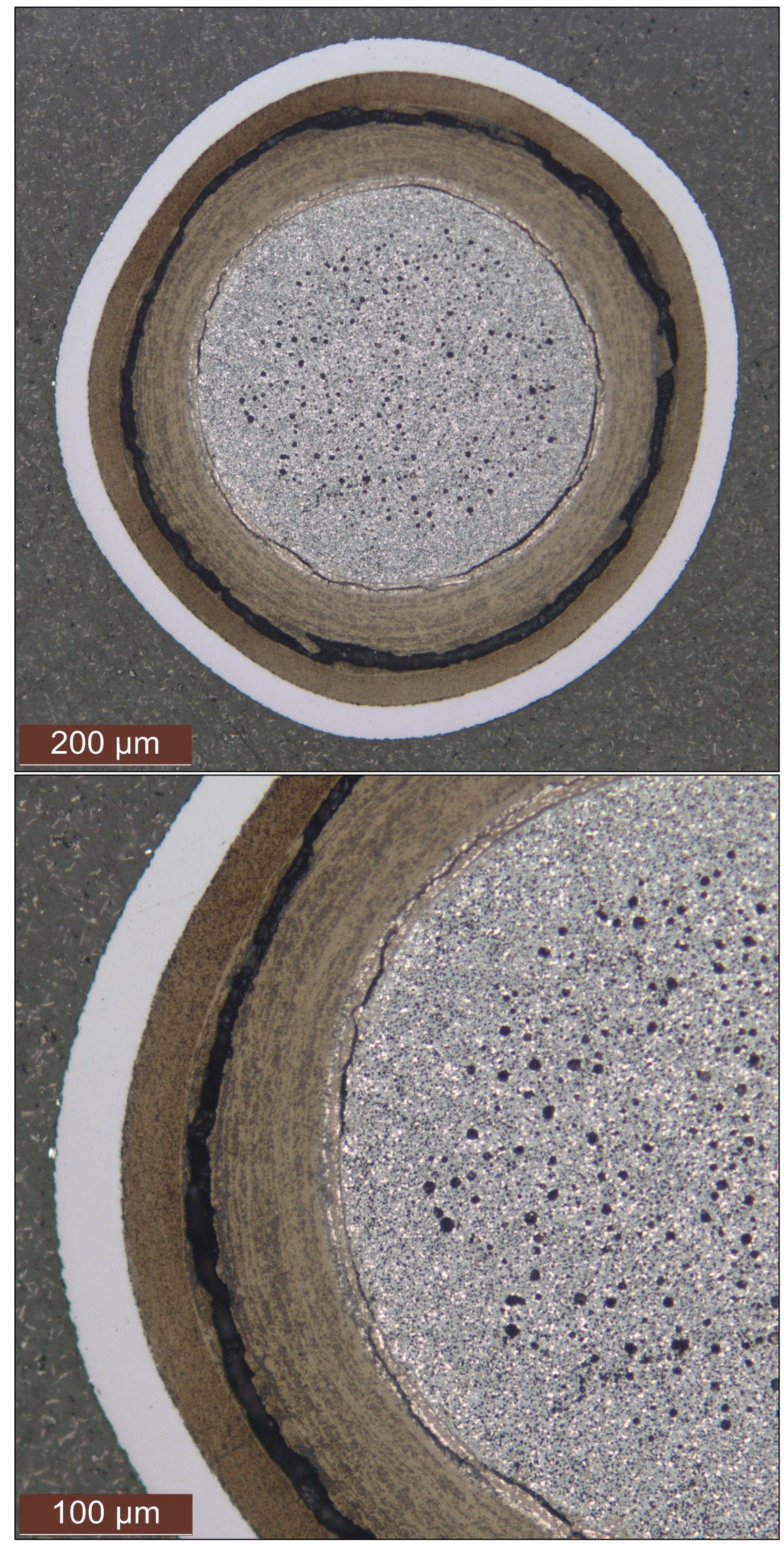

Figure 8. Particle 642-RS23 near midplane. 

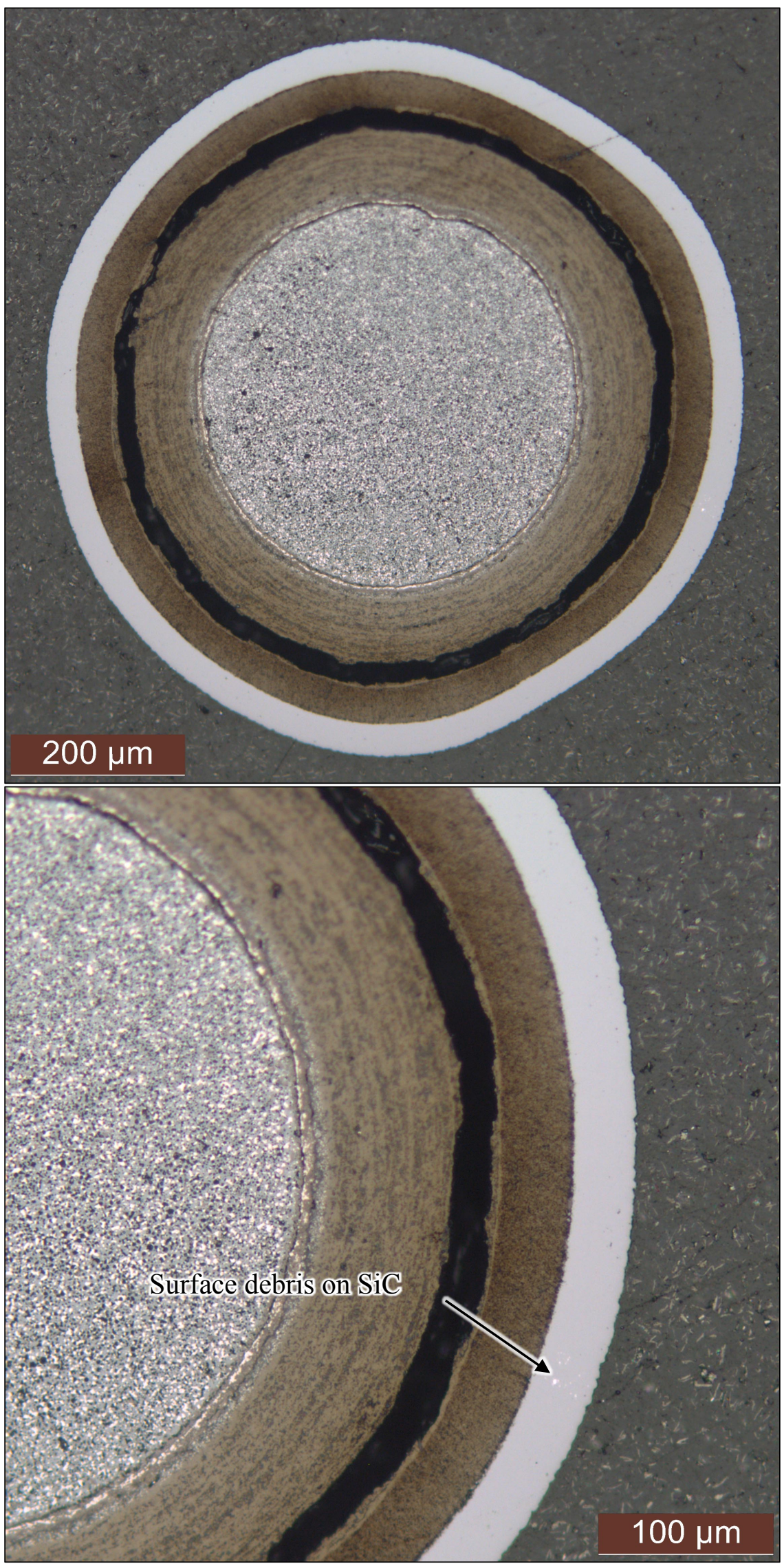

Figure 9. Particle 642-RS27 near midplane. 


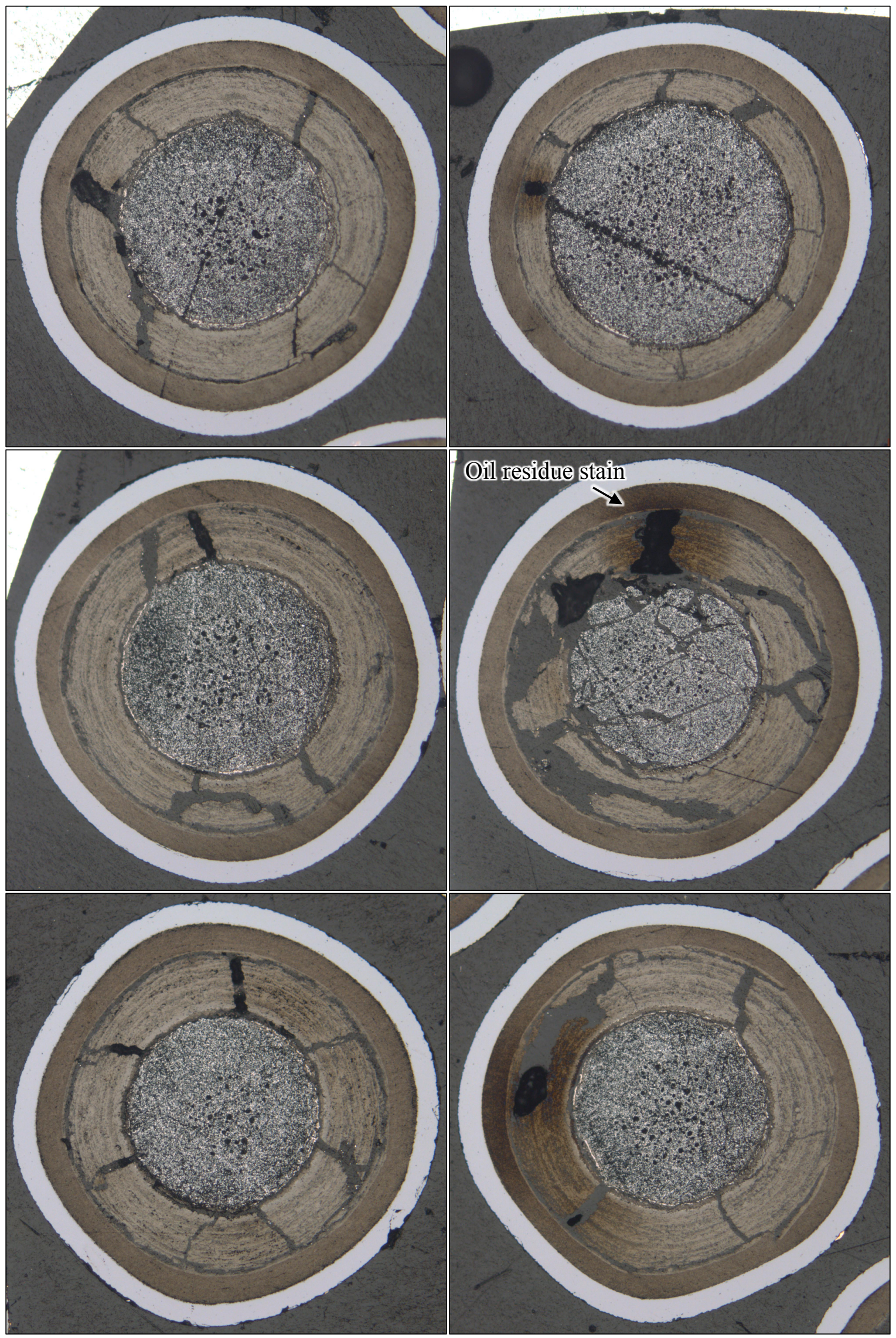

Figure 10. Images of randomly-selected particles from multiparticle mount MM-E10. 

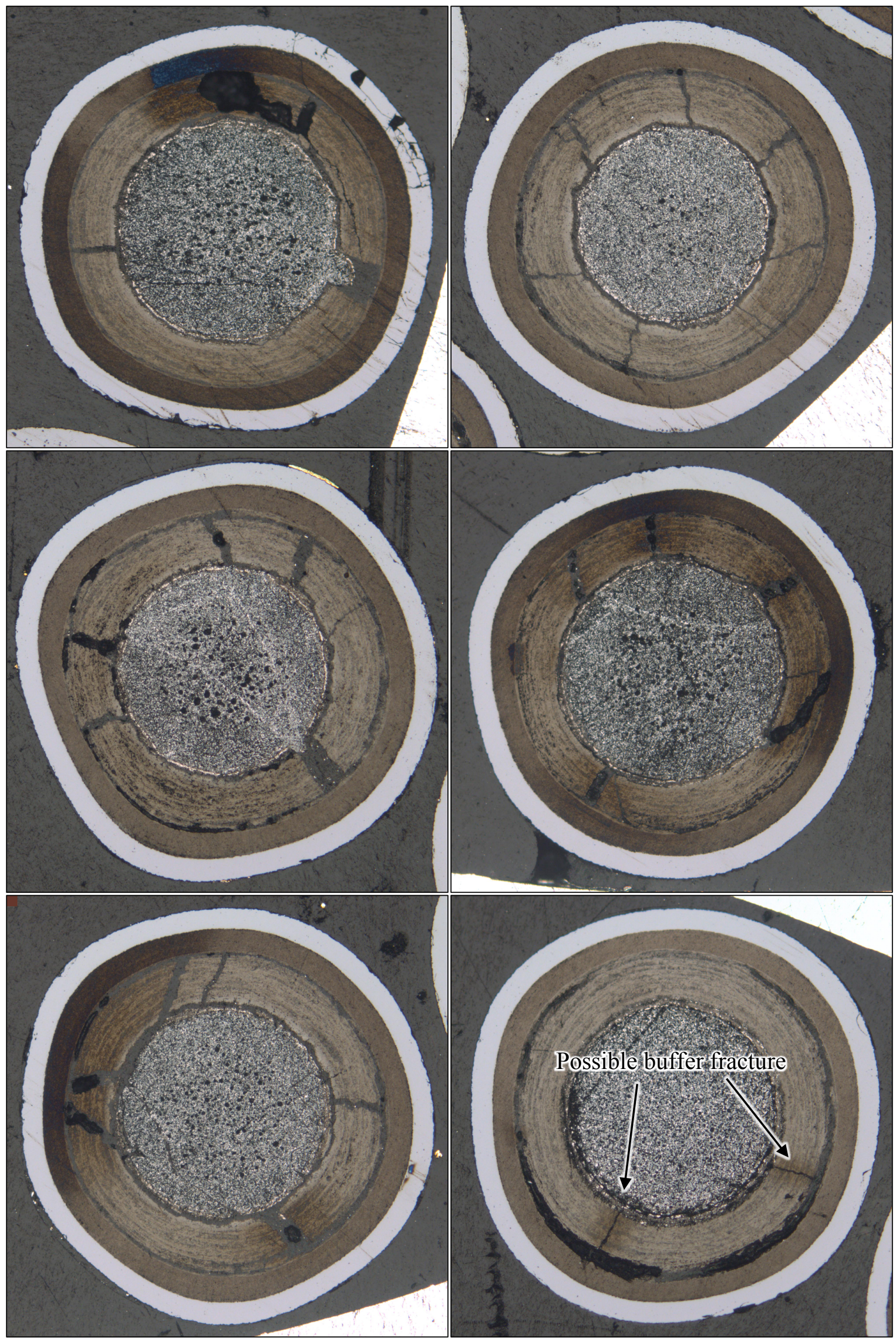

Figure 10 (continued). Images of randomly-selected particles from multiparticle mount MM-E10. 


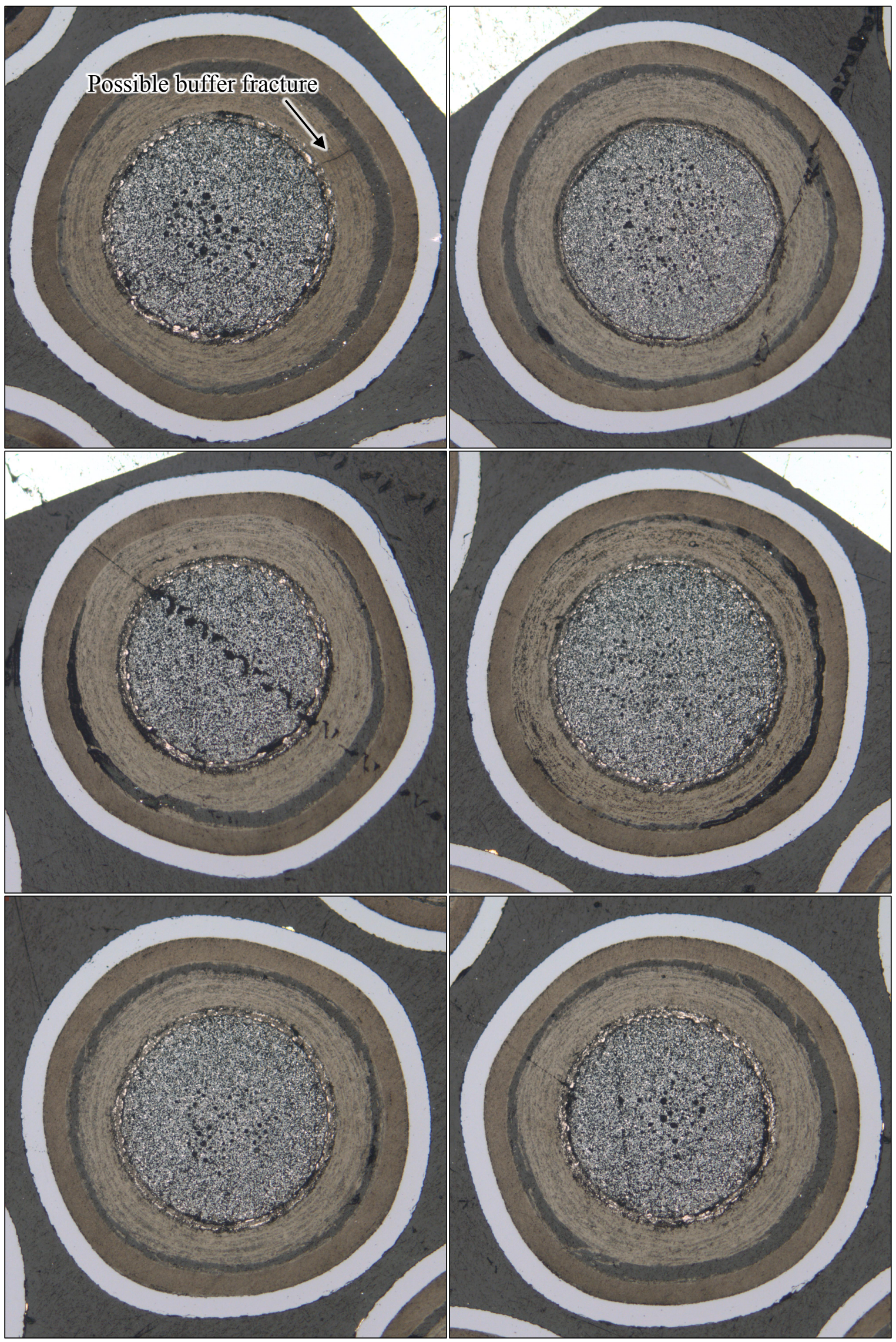

Figure 10 (continued). Images of randomly-selected particles from multiparticle mount MM-E10. 


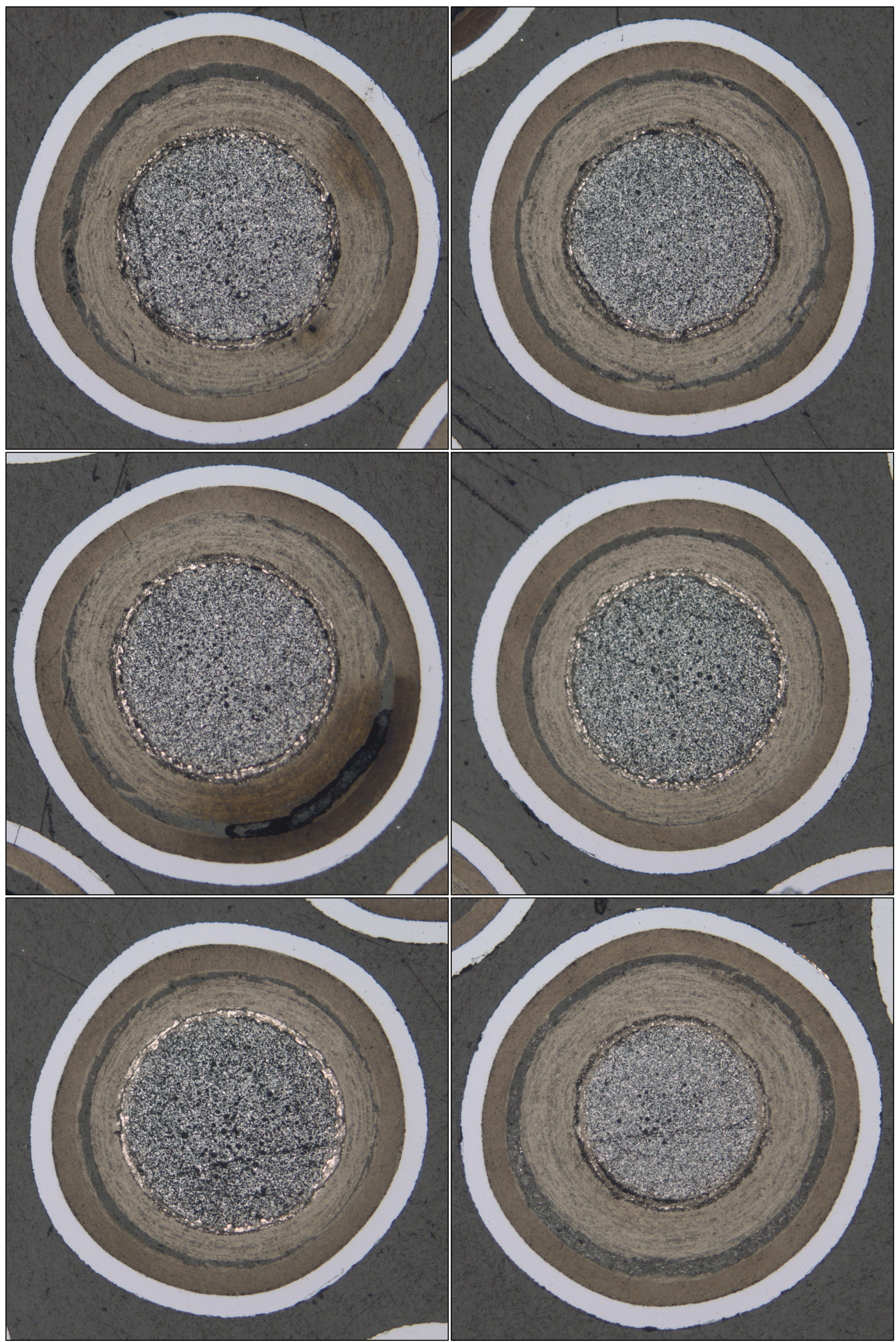

Figure 10 (continued). Images of randomly-selected particles from multiparticle mount MM-E10. 


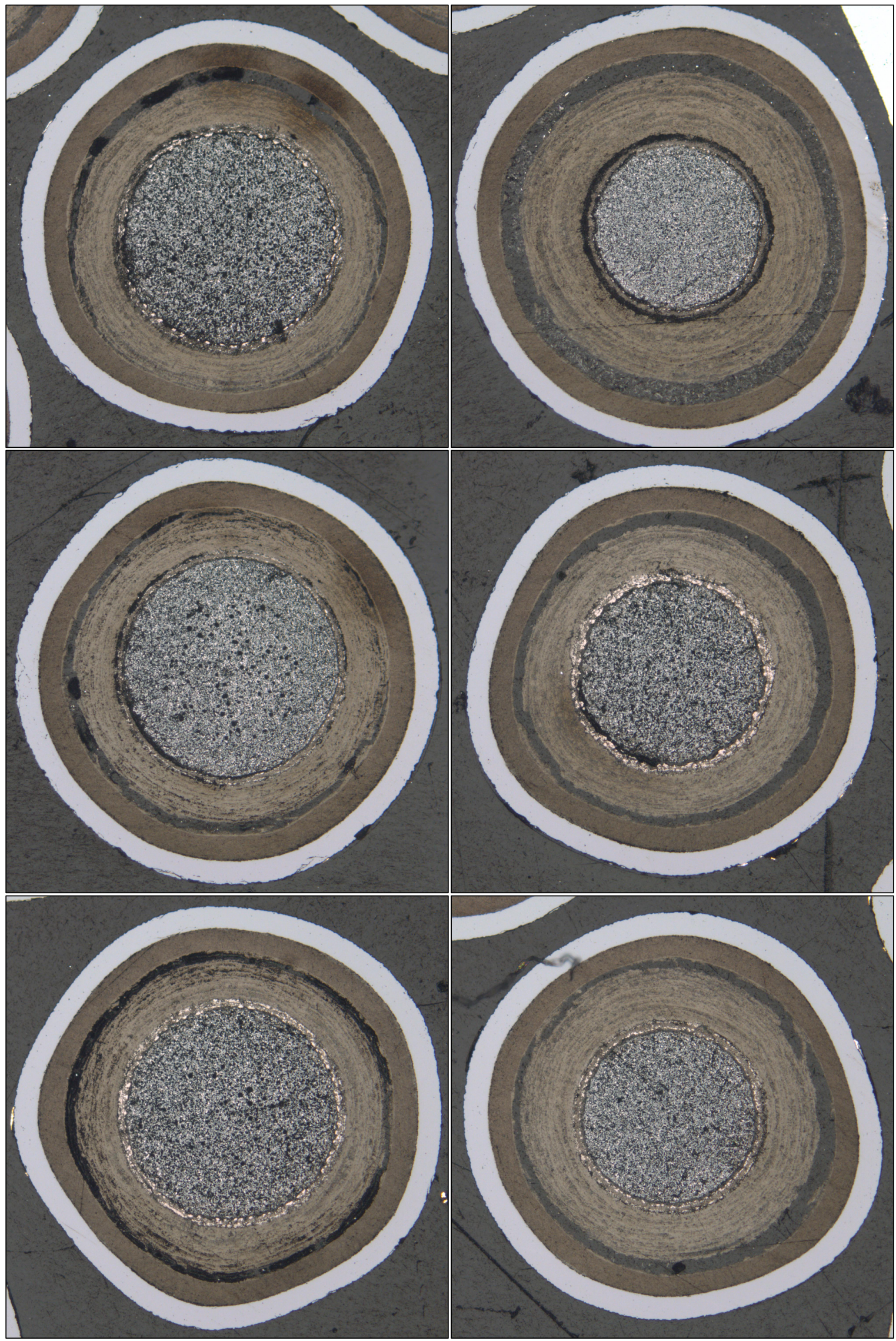

Figure 10 (continued). Images of randomly-selected particles from multiparticle mount MM-E10. 


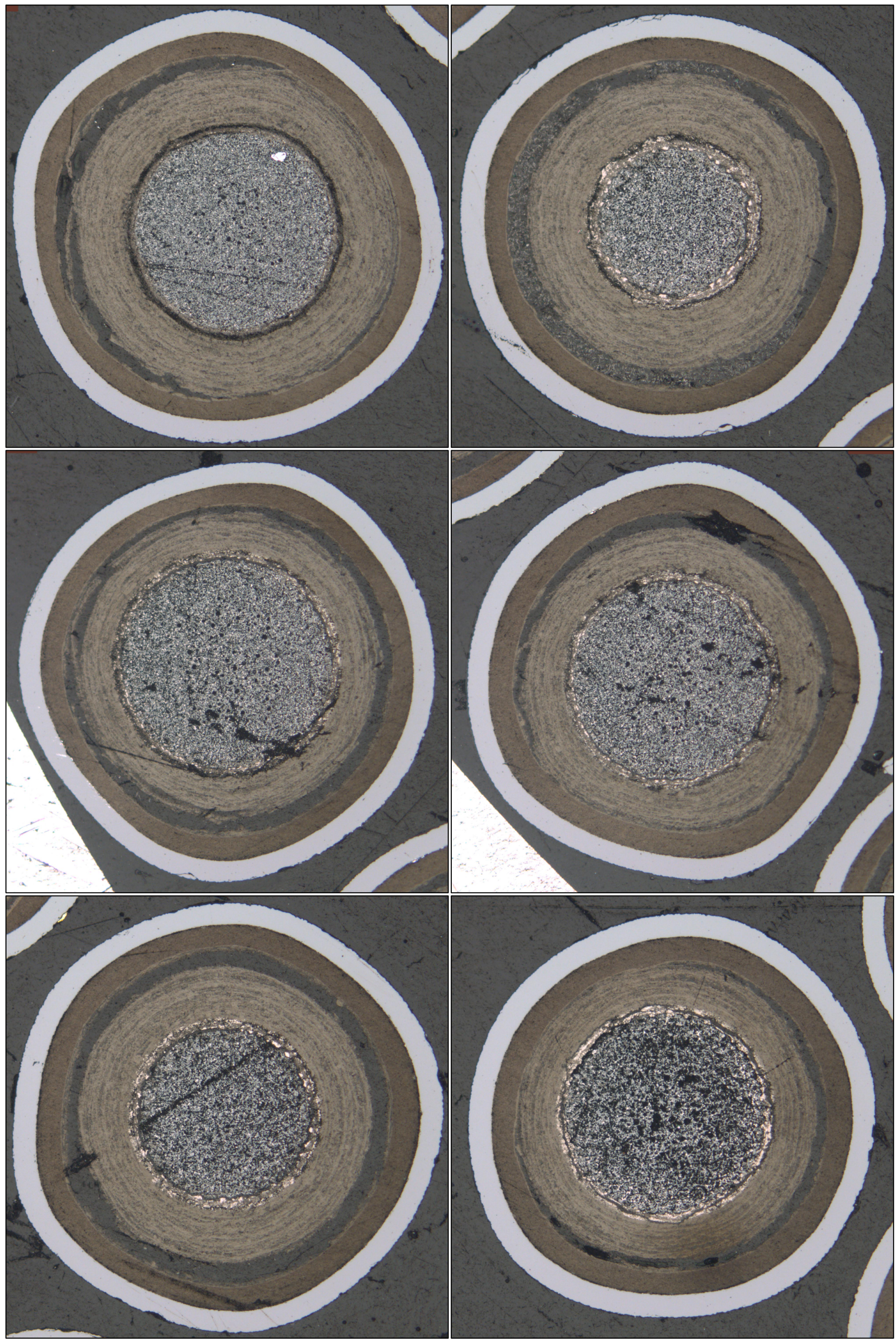

Figure 10 (continued). Images of randomly-selected particles from multiparticle mount MM-E10. 

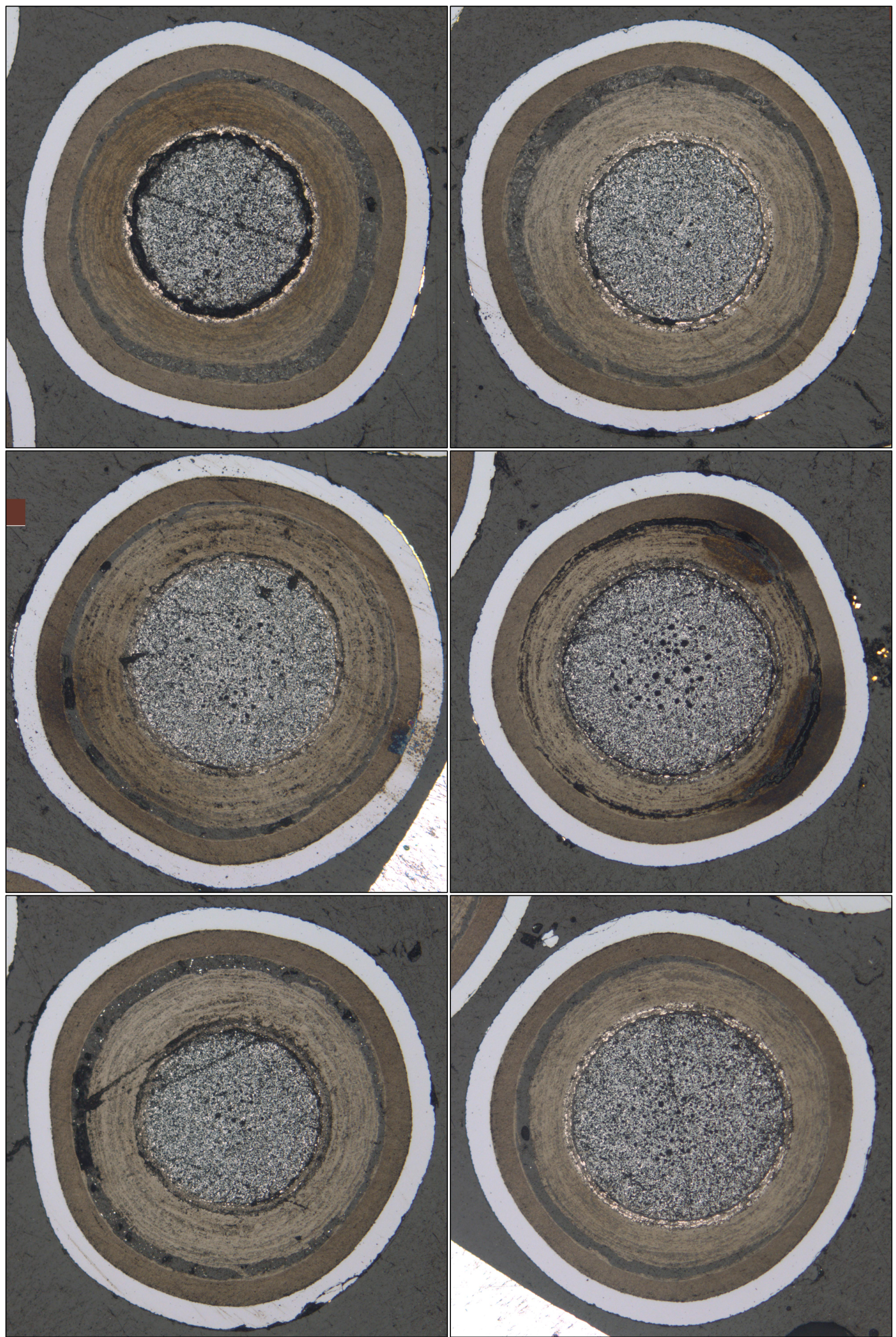

Figure 10 (continued). Images of randomly-selected particles from multiparticle mount MM-E10. 


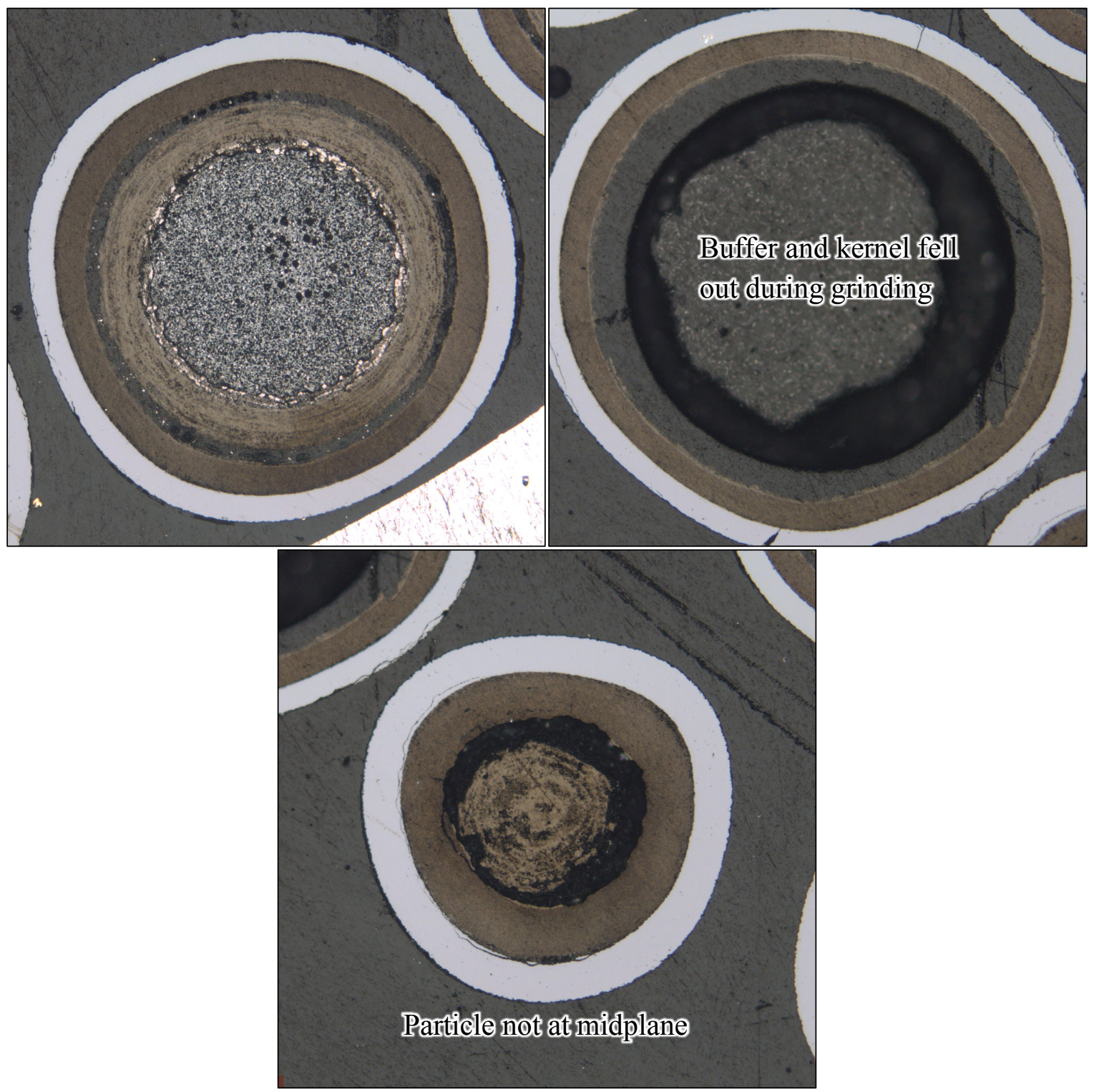

Figure 10 (continued). Images of randomly-selected particles from multiparticle mount MM-E10.

\subsection{SCANNING ELECTRON MICROSCOPY}

Details regarding SEM and EDS equipment and analysis methodology are reported in the PIE report for AGR-2 Compact 5-4-2 [Hunn et al. 2018]. Particles for SEM analysis from safety-tested Compact 6-4-2 were selected based on the ${ }^{110 \mathrm{~m}} \mathrm{Ag} \mathrm{M} / \mathrm{C}$ values determined by IMGA and can be categorized by three different silver inventory levels: low-silver (Particle $642-\mathrm{RS} 26$ with ${ }^{110 \mathrm{~m}} \mathrm{Ag} \mathrm{M} / \mathrm{C}<0.31$ ), average-silver (Particle 642-RS18 with ${ }^{110 \mathrm{~m}} \mathrm{Ag} \mathrm{M} / \mathrm{C}=0.81$ and Particle 642-RS44 with ${ }^{110 \mathrm{~m}} \mathrm{Ag} \mathrm{M} / \mathrm{C}=0.76$ ), and highsilver (Particle 642-RS23 with ${ }^{110 \mathrm{~m}} \mathrm{Ag} \mathrm{M} / \mathrm{C}=1.26$ and Particle $642-\mathrm{RS} 27$ with ${ }^{110 \mathrm{~m}} \mathrm{Ag} \mathrm{M} / \mathrm{C}=1.00$ ). Lowsilver Particle $642-\mathrm{RS} 26$ had a ${ }^{110 \mathrm{~m}} \mathrm{Ag}$ inventory below the limits of detection for the IMGA six-hour count and can be confidently presumed to have released a majority of its silver inventory. Likewise, the high-silver particles can be confidently presumed to have retained a majority of their silver inventory. Particles in the average-silver category are difficult to classify in terms of silver release. If these particles started with ${ }^{110 \mathrm{~m}} \mathrm{Ag}$ inventories on the high-end of the ${ }^{110 \mathrm{~m}} \mathrm{Ag}$-generation distribution, then they may have lost about half their silver, whereas if they started at the low-end of the ${ }^{110 \mathrm{~m}} \mathrm{Ag}$-generation distribution, then they may have retained a majority of their silver. The buffer and kernel from Particle 642-RS27 was lost during ultrasonic cleaning and decontamination and therefore was not observed in the SEM analysis. 
Figure 11-Figure 15 show overview micrographs of the buffer, IPyC, and SiC layers for all particles analyzed by SEM using backscattered-electron composition (BEC) imaging. No OPyC was present because the particles were imaged after burn-leach. Bright spots that indicate the pileup of fission products with atomic number $(\mathrm{Z})$ higher than carbon and silicon were observed near the IPyC/SiC boundary (defined as the evident demarcation between primarily $\mathrm{SiC}$ material and primarily IPyC material). The nature of the pileup varied around the circumference of the IPyC/SiC boundary region in intensity, feature size, and distance from the boundary. In some cases, high-intensity features were observed to be segregated along bands located a few microns into the IPyC side of the boundary. The location of these bands may have been related to the width of the IPyC/SiC interfacial region formed by $\mathrm{SiC}$ infiltration into the open porosity of the IPyC at the beginning of SiC deposition. Diffuse pileup features were also observed in the IPyC side of the boundary that may be lower concentration pileup of fission products or buried features. Another class of pileup feature consisted of high-intensity spots that appeared to be directly on the IPyC/SiC boundary (Figure 13) or even extending into the $\mathrm{SiC}$ side of the boundary. These features varied from a small isolated spot to large-scale features measuring tens of microns across.

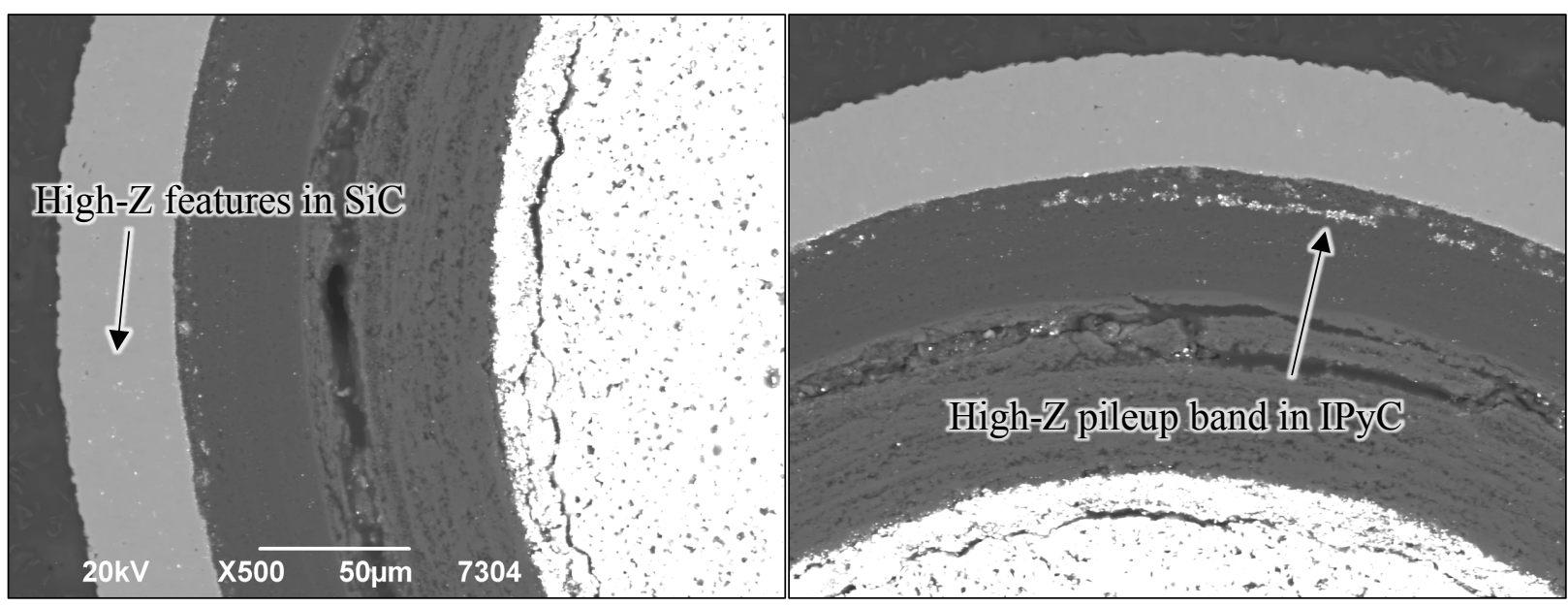

Figure 11. Two 500x BEC images of Particle 642-RS26 with ${ }^{110} \mathrm{Ag} \mathrm{M} / \mathrm{C}<0.31$.

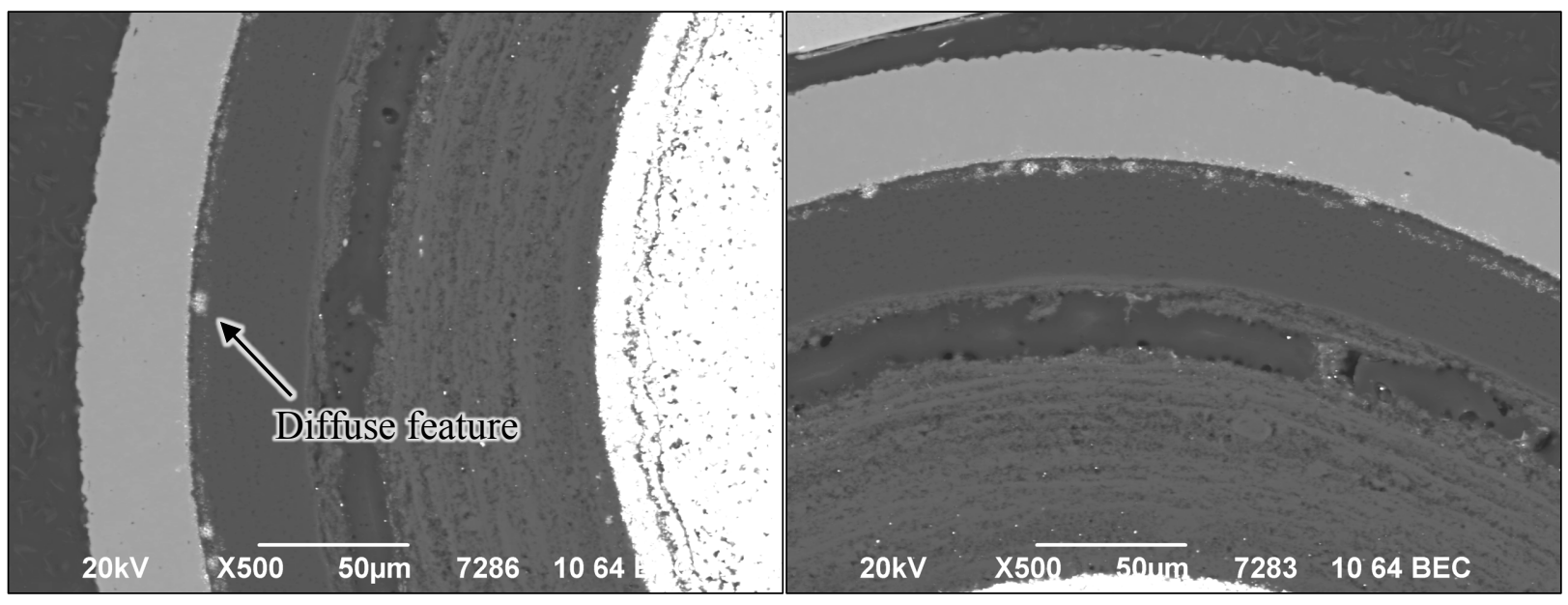

Figure 12. Two 500x BEC images of Particle 642-RS18 with ${ }^{110} \mathrm{Ag} \mathrm{M} / \mathrm{C}=0.81$. 


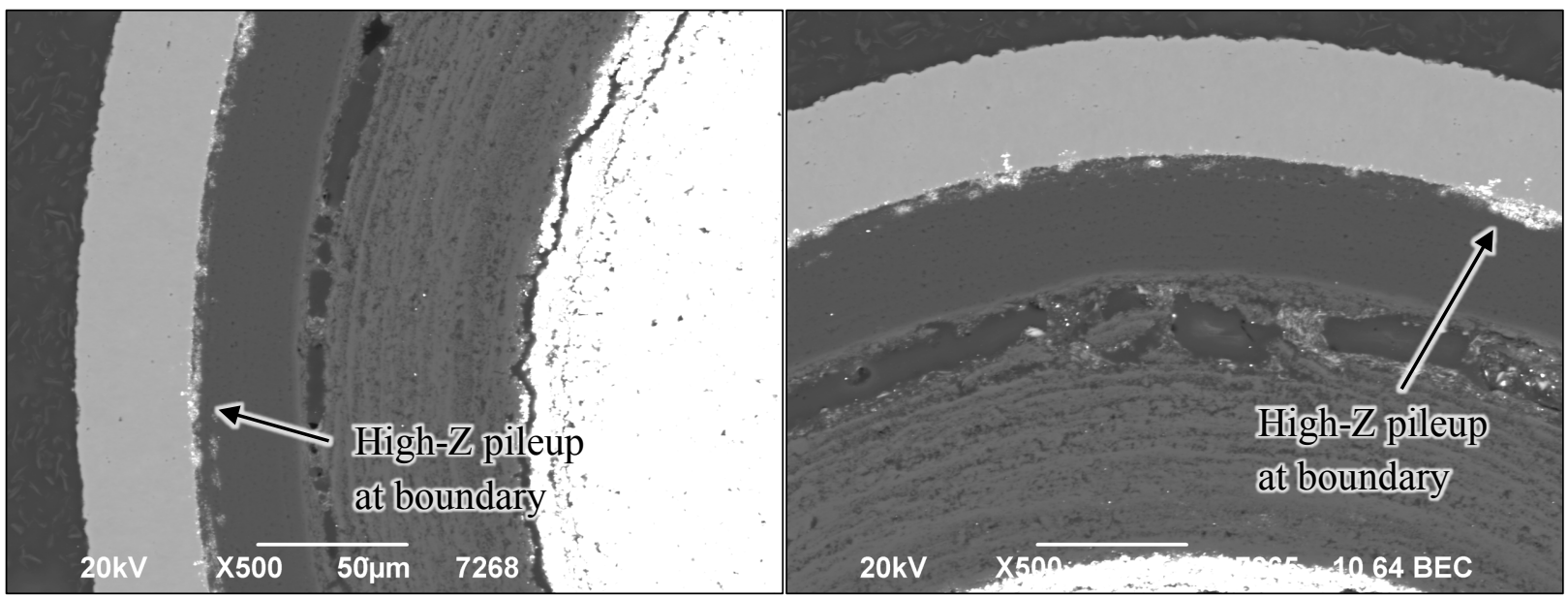

Figure 13. Two 500x BEC images of Particle 642-RS44 with ${ }^{110} \mathrm{Ag} \mathrm{M} / \mathrm{C}=0.76$.

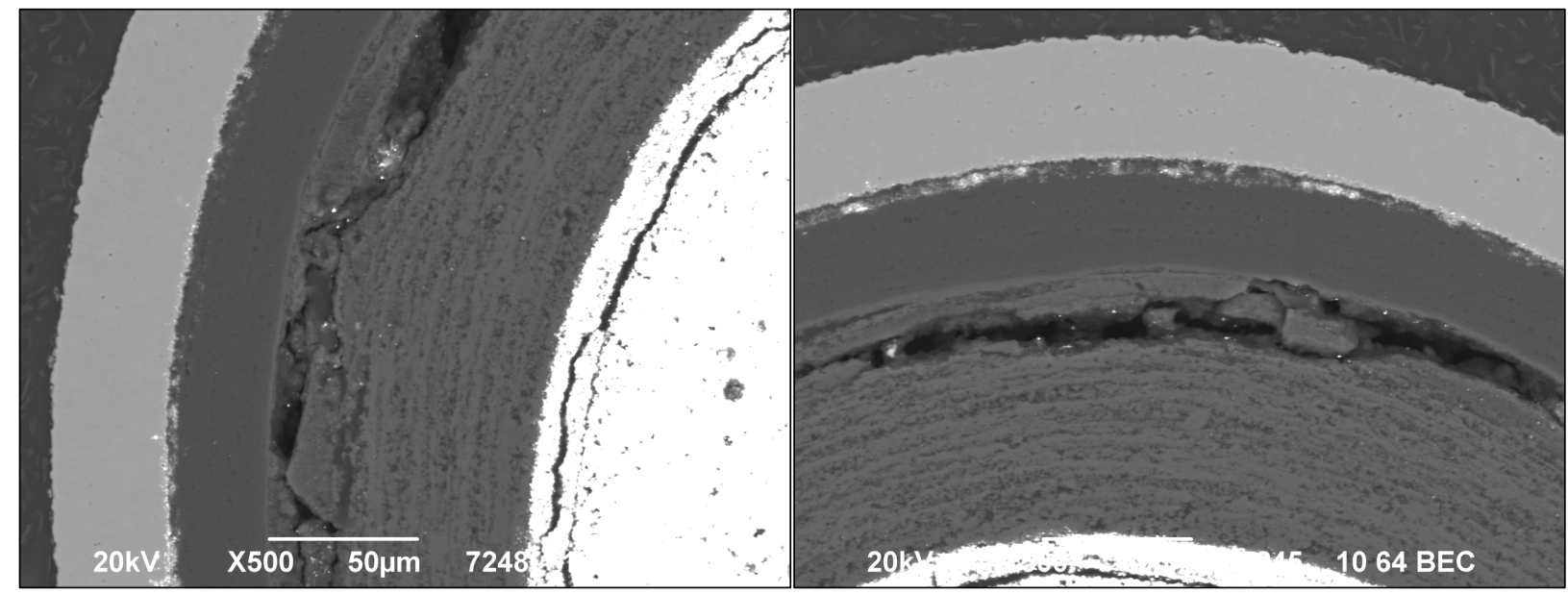

Figure 14. Two 500x BEC images of Particle 642-RS23 with ${ }^{110} \mathrm{Ag} \mathrm{M} / \mathrm{C}=1.26$.

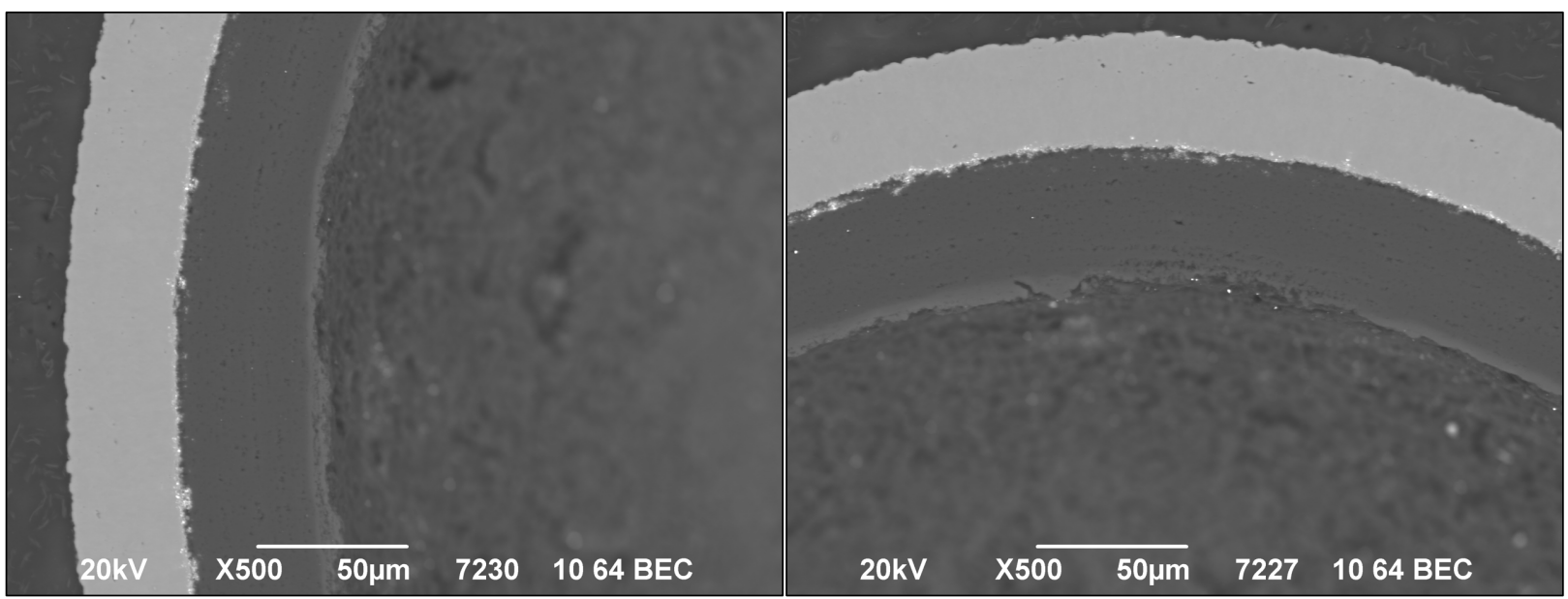

Figure 15. Two 500x BEC images of Particle 642-RS27 with ${ }^{110} \mathrm{Ag} \mathrm{M} / \mathrm{C}=1.00$.

Figure 16 is an obvious example of high-Z features co-located with $\mathrm{SiC}$ that had infiltrated into the IPyC pores. This implies that the nature of the $\mathrm{IPyC} / \mathrm{SiC}$ interface and the IPyC structure may impact fission product accommodation. 


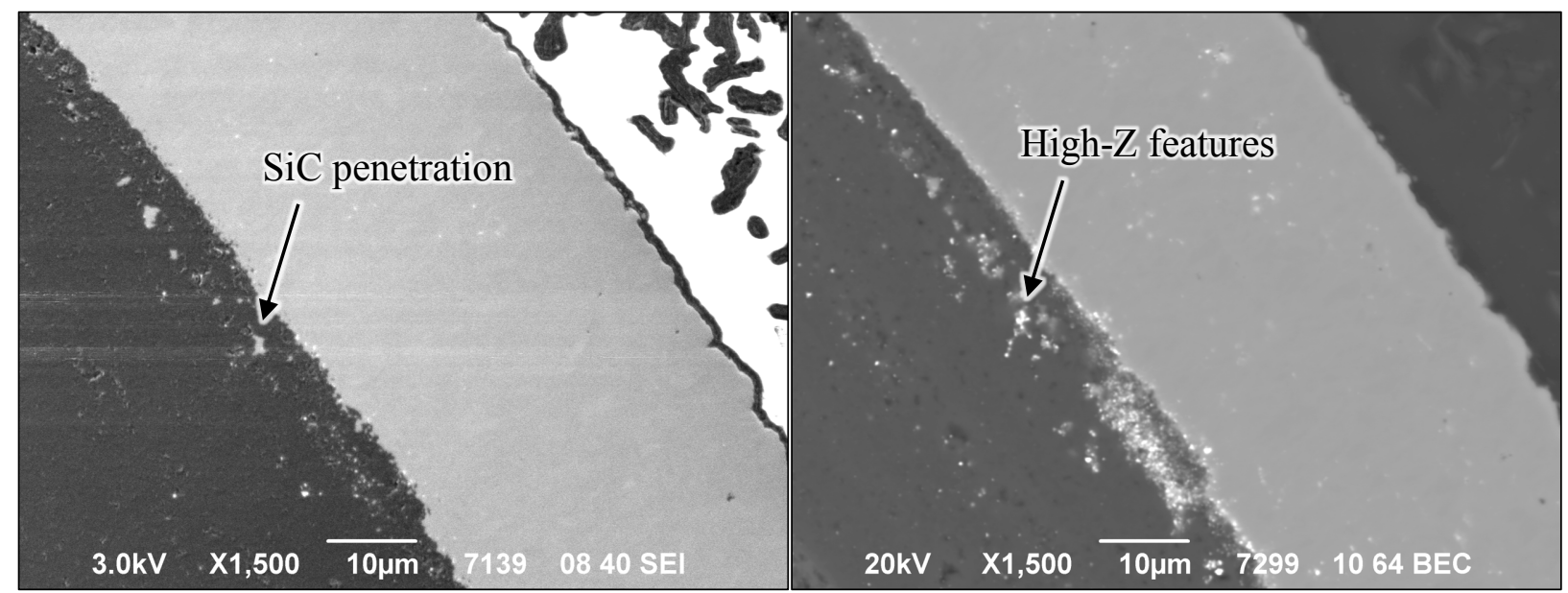

Figure 16. Comparision of $\mathrm{SE}$ and BEC image pairs of Particle 642-RS26 $\left({ }^{110} \mathrm{Ag} \mathrm{M} / \mathrm{C}=0.31\right)$ showing several unusually-large $\mathrm{SiC}$ features on IPyC side of the IPyC/SiC boundary and related high-Z features.

Some degree of penetration of high- $\mathrm{Z}$ features into the $\mathrm{SiC}$ layer was observed in all particles. In the overview micrographs, the penetration was most-readily visible as bright spots in the SiC layer of lowsilver Particle 642-RS26 (Figure 11). Figure 17 shows a comparison of a secondary-electron (SE) image and a BEC micrograph from Particle 642-RS26. This comparison helps confirm the high-Z features visible in the BEC image are embedded in the SiC layer and not surface features left behind after sample preparation, as no indication of shadowing or surface topography was observed in the corresponding SE image. The embedded nature of fission products in the $\mathrm{SiC}$ layer has also been observed and confirmed in previous analysis by SEM [Gerczak et al. 2016] and transmission electron microscopy [van Rooyen et al. 2014].

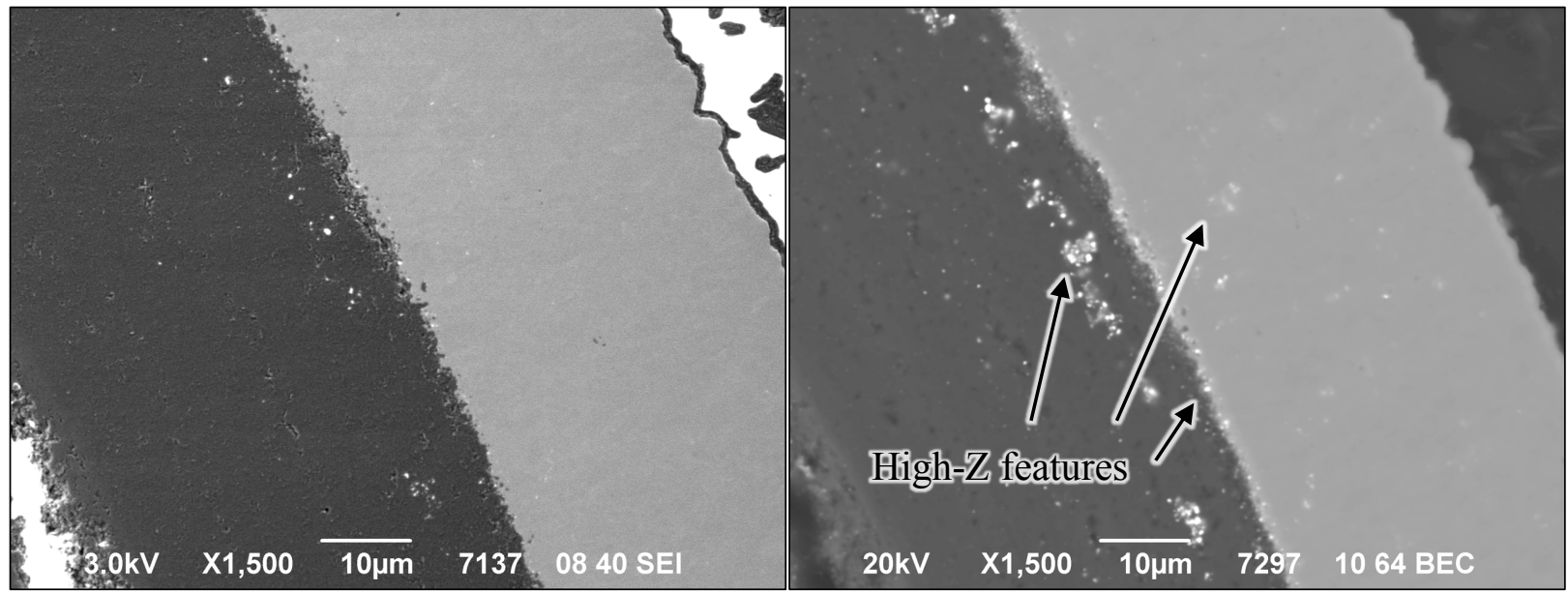

Figure 17. Comparision of SE and BEC image pairs of low-silver Particle 642-RS26 showing embedded high-Z features on both sides of the IPyC/SiC boundary.

The extent of penetration varied for particles with different ${ }^{110 \mathrm{~m}} \mathrm{Ag} \mathrm{M} / \mathrm{C}$, as shown in higher magnification BEC micrographs for each particle (Figure 18-Figure 22). High-Z features were observed across the entire $\mathrm{SiC}$ layer for the low-silver particle (Figure 18). For the average- and high-silver particles (Figure 19-Figure 22), the high- $Z$ feature penetration was limited to the region immediately adjacent to the $\mathrm{IPyC} / \mathrm{SiC}$ boundary (within about $5 \mu \mathrm{m}$ ). Isolated high- $\mathrm{Z}$ features were also observed in the IPyC layer. These features we observed with greater frequency in the low-silver particle (Figure 18) than in the average and high-silver particles, which showed limited features in the IPyC layer. 


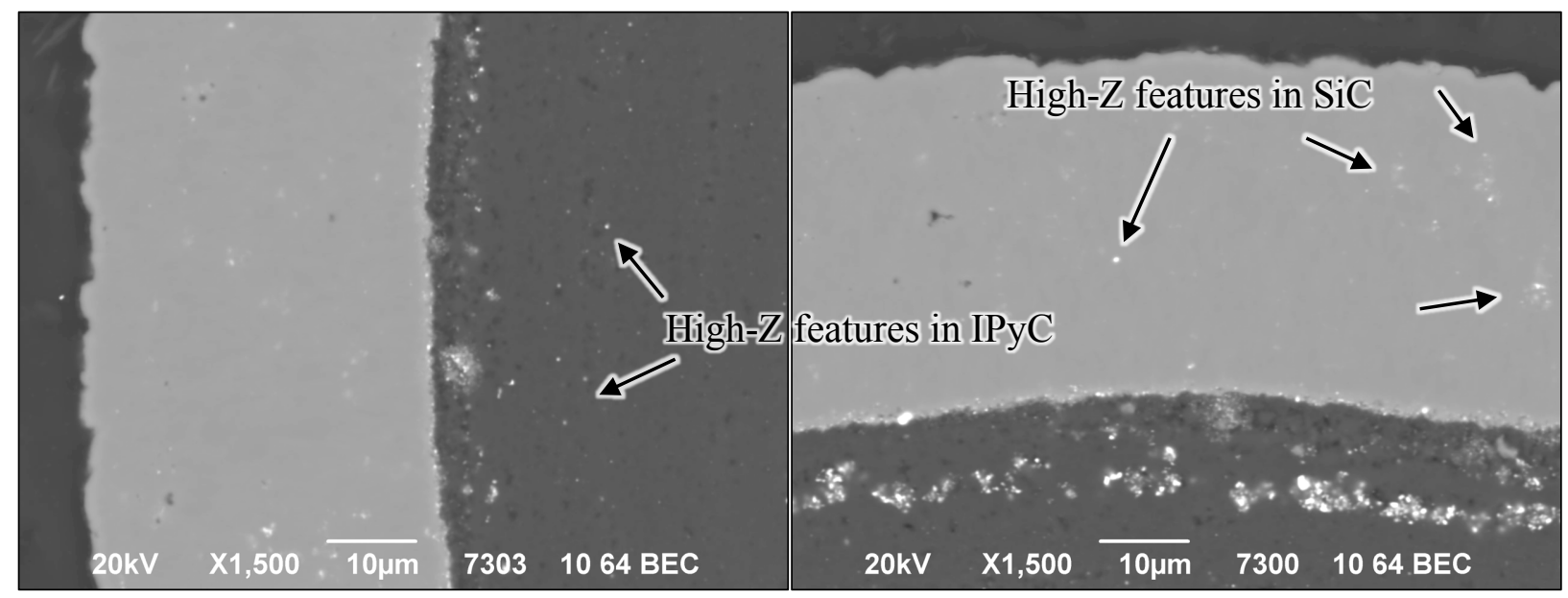

Figure 18. Two 1500x BEC images of Particle 642-RS26 with ${ }^{110} \mathrm{Ag} \mathrm{M} / \mathrm{C}<0.31$.

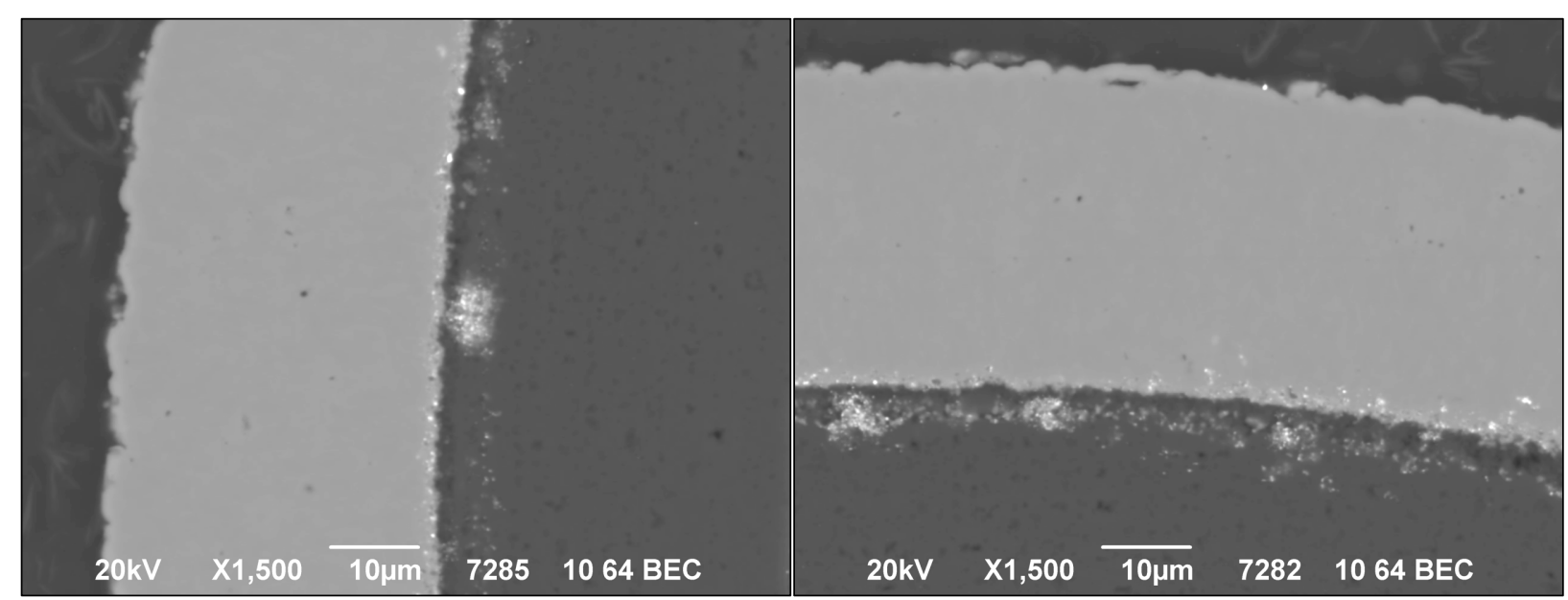

Figure 19. Two 1500x BEC images of Particle $642-\mathrm{RS18}$ with ${ }^{110} \mathrm{Ag} \mathrm{M} / \mathrm{C}=0.81$.

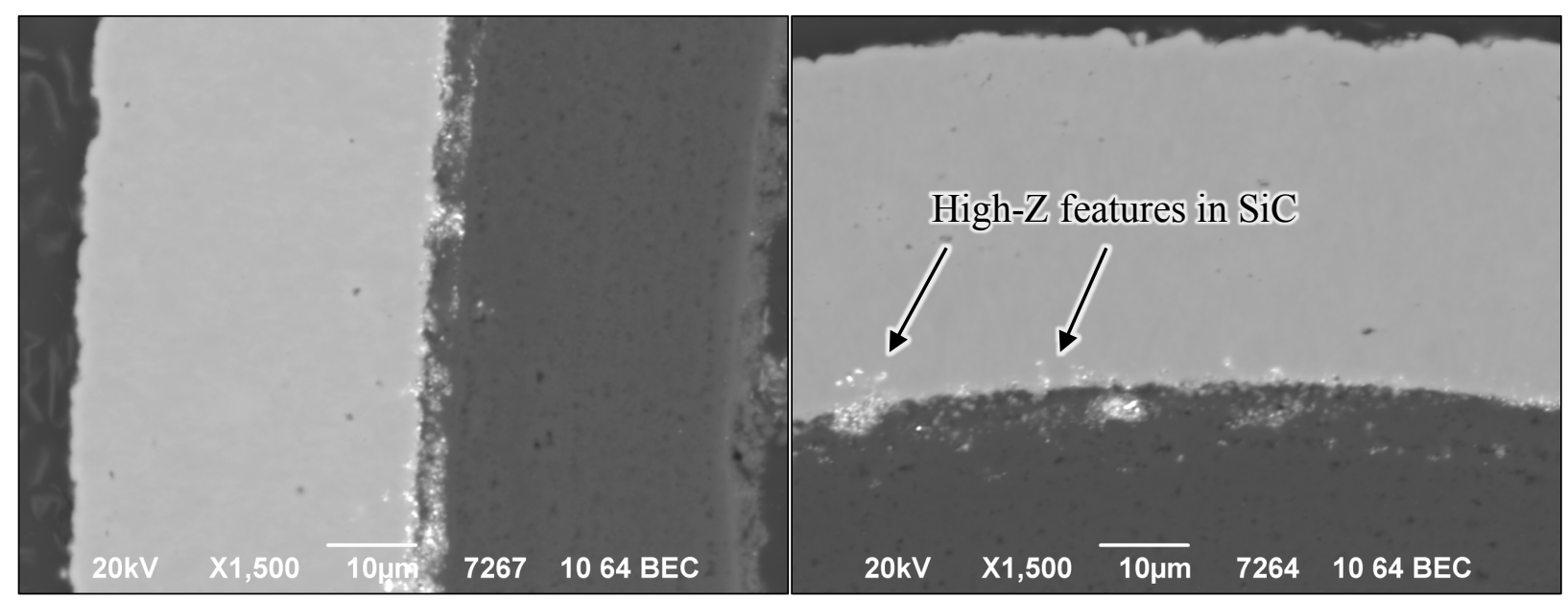

Figure 20. Two 1500x BEC images of Particle 642-RS44 with ${ }^{110} \mathrm{Ag} \mathrm{M} / \mathrm{C}=0.76$. 


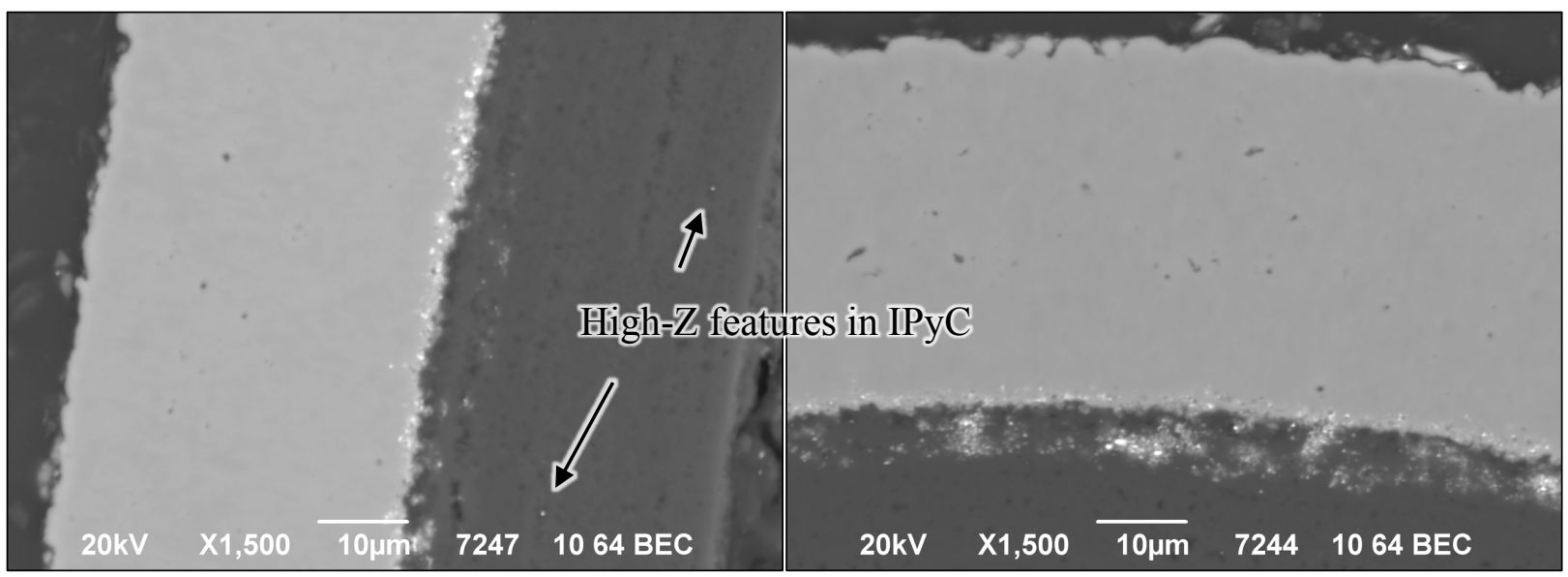

Figure 21. Two 1500x BEC images of Particle 642-RS23 with ${ }^{110} \mathrm{Ag} \mathrm{M} / \mathrm{C}=1.26$.

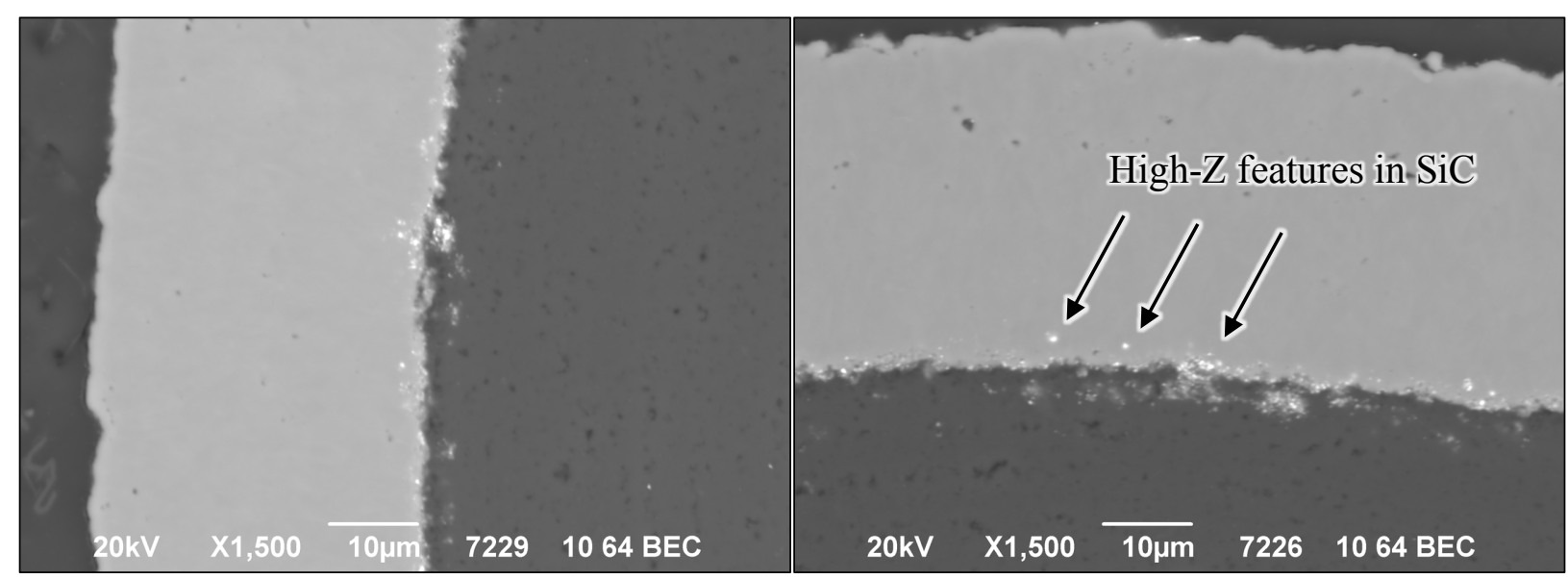

Figure 22. Two 1500x BEC images of Particle 642-RS27 with ${ }^{110} \mathrm{Ag} \mathrm{M} / \mathrm{C}=1.00$.

Select locations showed a greater degree of pileup and high-Z feature penetration into the $\mathrm{SiC}$ side of the $\mathrm{IPyC} / \mathrm{SiC}$ boundary than was observed at most locations around the circumference. Examples of these features are shown in Figure 23-Figure 26. In some instances, corresponding low- $Z$ features in the $\mathrm{SiC}$ were observed along with the high- $Z$ features. This behavior was similar to the reaction observed between palladium and $\mathrm{SiC}$ in safety-tested AGR-1 particles with failed $\mathrm{SiC}$ [Hunn et al. 2014], however, the extent of the $\mathrm{SiC}$ attack was minimal compared to what was observed in failed-SiC particles.

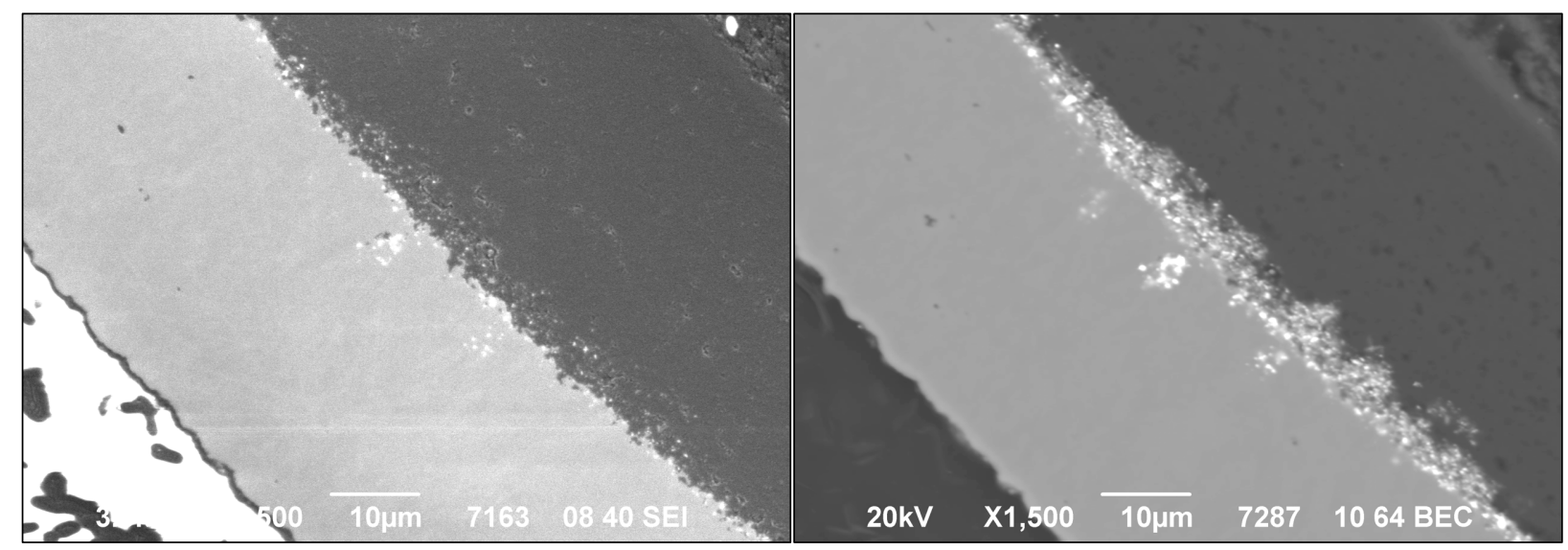

Figure 23. Comparision of $\mathrm{SE}$ and BEC image pairs of Particle $642-\mathrm{RS18}\left({ }^{110} \mathrm{Ag} \mathrm{M} / \mathrm{C}=0.81\right)$ showing the result of fission product interaction with the $\mathrm{SiC}$. 


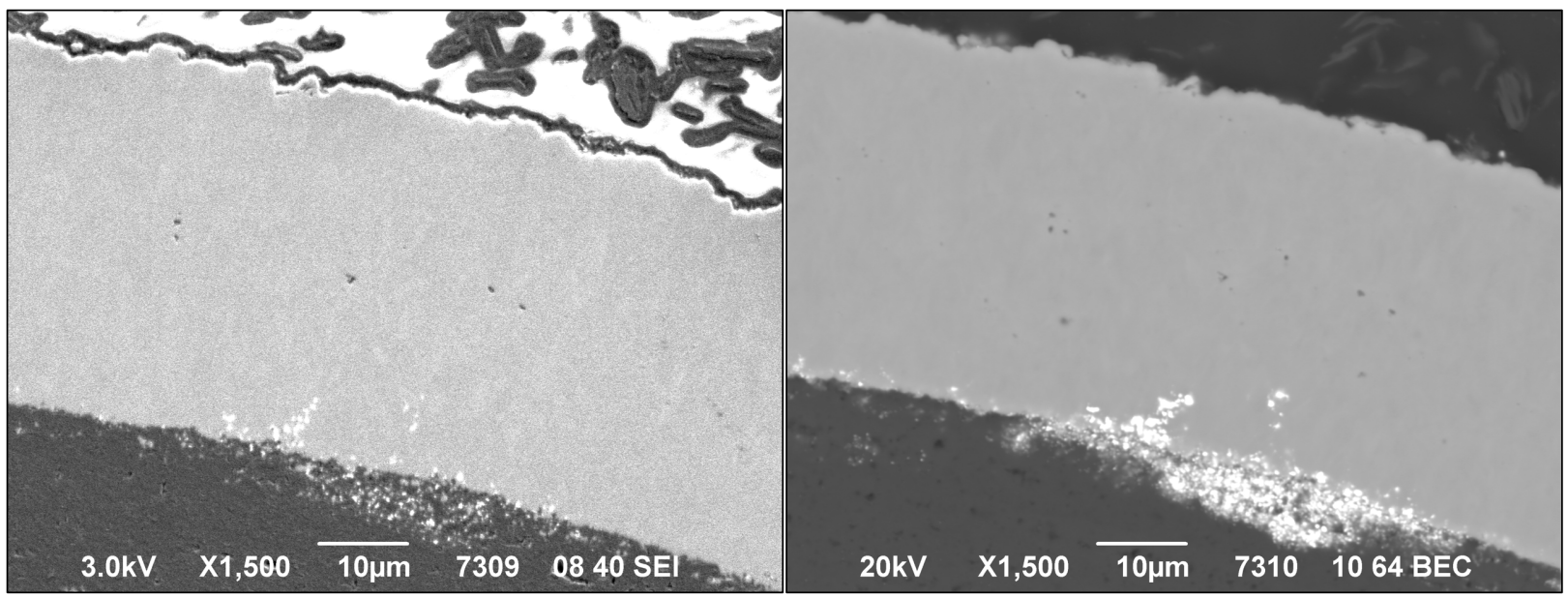

Figure 24. Comparision of SE and BEC image pairs of Particle $642-\mathrm{RS44}\left({ }^{110} \mathrm{Ag} \mathrm{M} / \mathrm{C}=0.76\right)$ showing the result of fission product interaction with the $\mathrm{SiC}$.

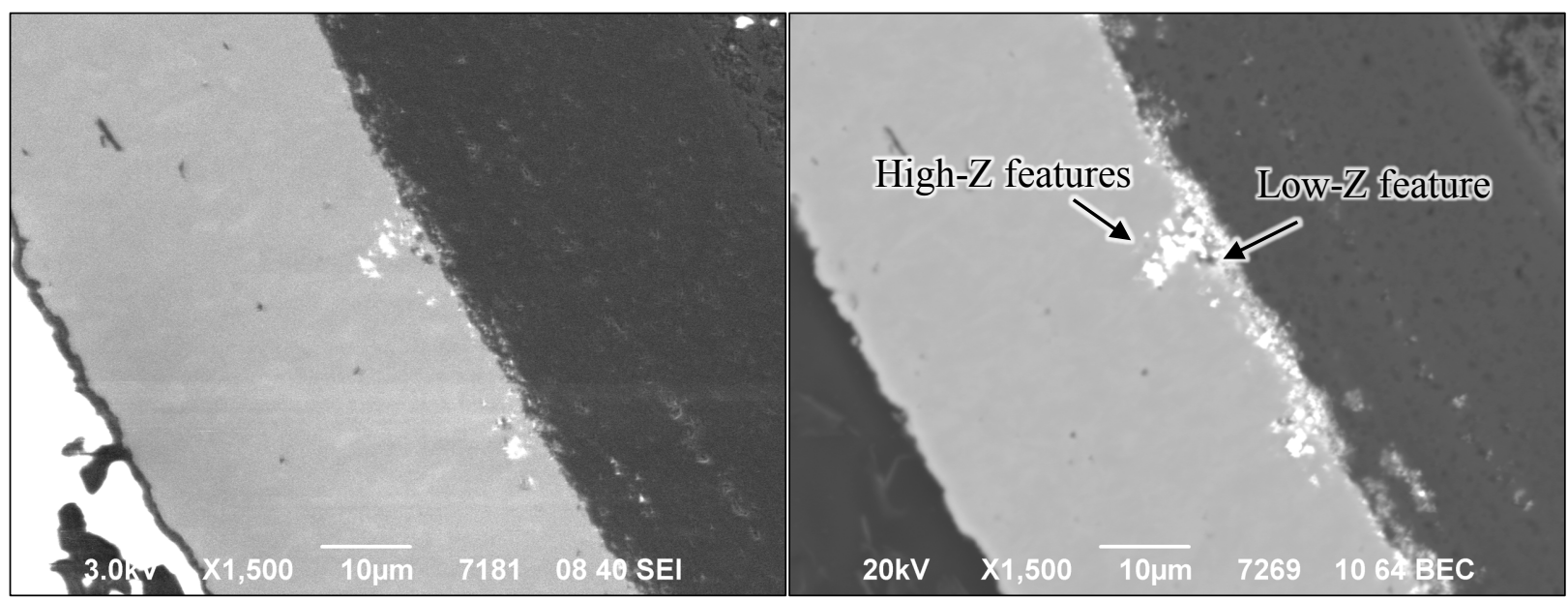

Figure 25. Comparision of SE and BEC image pairs of Particle 642-RS44 $\left({ }^{110} \mathrm{Ag} \mathrm{M} / \mathrm{C}=0.76\right)$ showing the result of fission product interaction with the $\mathrm{SiC}$.

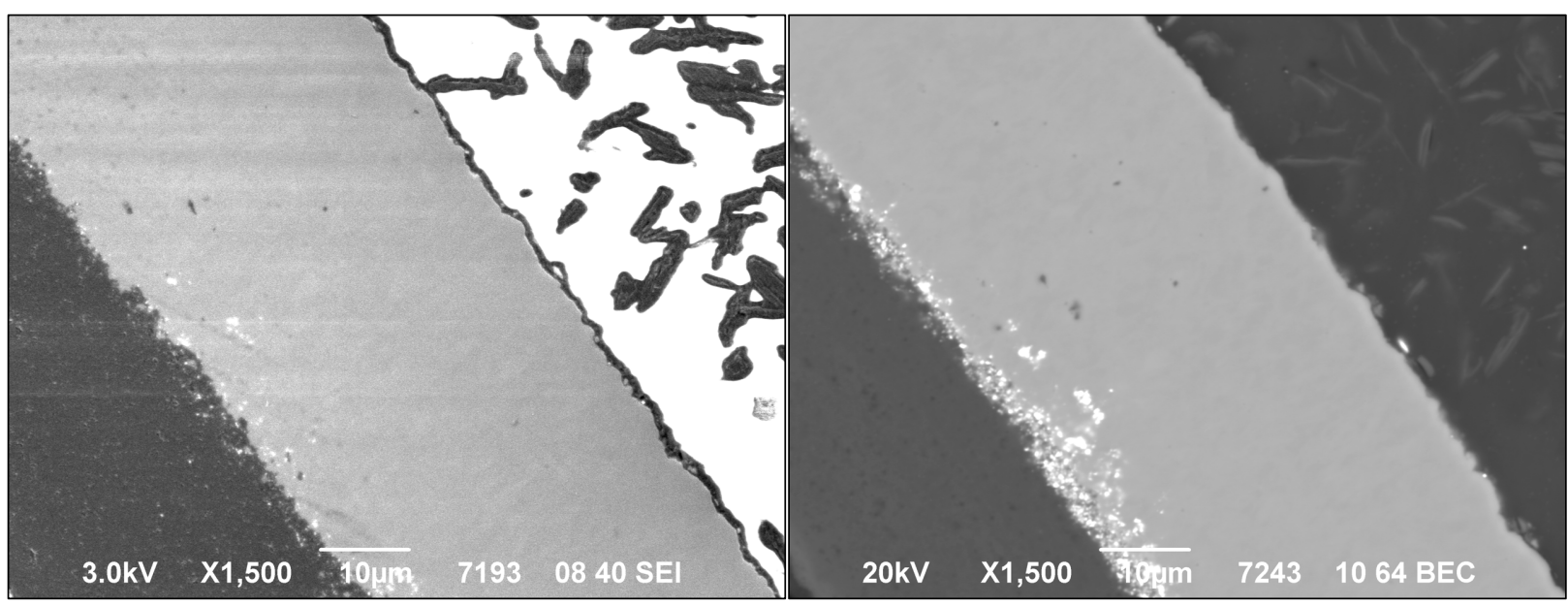

Figure 26. Comparision of SE and BEC image pairs of Particle $642-\mathrm{RS23}\left({ }^{110} \mathrm{Ag} \mathrm{M} / \mathrm{C}=1.26\right)$ showing the result of fission product interaction with the SiC. 
The composition of the high-Z features was examined with EDS Point-ID to provide insight on the distribution of fission products in the IPyC and SiC. Feature types were grouped in five general EDS categories: 1) "Pd-only" features only produced discernable palladium peaks, 2) "Pd-U" features produced significant peaks for both palladium and uranium (with a higher concentration of palladium than uranium), 3) "U-Pd" features produced significant peaks for both palladium and uranium (with a higher concentration of uranium than palladium), 4) "U-Zr" features produced significant peaks for both uranium and zirconium, and 5) "IPyC" features which commonly contained $\mathrm{U}, \mathrm{Zr}, \mathrm{Sr}, \mathrm{Si}, \mathrm{Cs}$, and Ba. The Pd-only, $\mathrm{Pd}-\mathrm{U}$, and U-Pd features likely contained palladium and uranium silicides based on prior observations from AGR-1 analysis [van Rooyen et al. 2014] and the higher ratio of silicon in the EDS spectra (using standardless analysis and comparison to $\mathrm{SiC}$ reference spectra).

Low-silver Particle 642-RS26 showed a variation in feature composition in the SiC layer. The observed features in the $\mathrm{SiC}$ more than $5 \mu \mathrm{m}$ from the IPyC/SiC boundary were predominantly Pd-only features with a few Pd-U features. Figure 27 shows a representative area and Figure 28 shows the spectra of the Pd-only and Pd-U features identified in Figure 27. Features in the SiC layer within $5 \mu \mathrm{m}$ of the IPyC/SiC boundary were predominantly $\mathrm{Pd}-\mathrm{U}$ features, but the majority differed from the Pd-U features more than $5 \mu \mathrm{m}$ from the IPyC/SiC boundary in that they showed minor compositional variations that included additional fission products (Figure 29). In particular, the presence of trace rhodium and plutonium were noted. The confirmation of plutonium was difficult due to the low counts, overlap with $U-M_{\beta 1}$ and the $\mathrm{Si}+\mathrm{Si}$ sum peak. The presence of plutonium was inferred based on a higher ratio of intensities for uranium $\mathrm{U}-\mathrm{M}_{\beta}: \mathrm{U}-\mathrm{M}_{\alpha 1}$ because $\mathrm{Pu}-\mathrm{M}_{\alpha}(3.350 \mathrm{keV})$ overlaps $\mathrm{U}-\mathrm{M}_{\beta}(3.337 \mathrm{keV})$. The presence of rhodium was clear from the shoulder off the $\mathrm{Pd}-\mathrm{L}_{\alpha 1}$ peak at $2.696 \mathrm{keV}$ corresponding to $\mathrm{Rh}-\mathrm{L}_{\alpha 1}$.

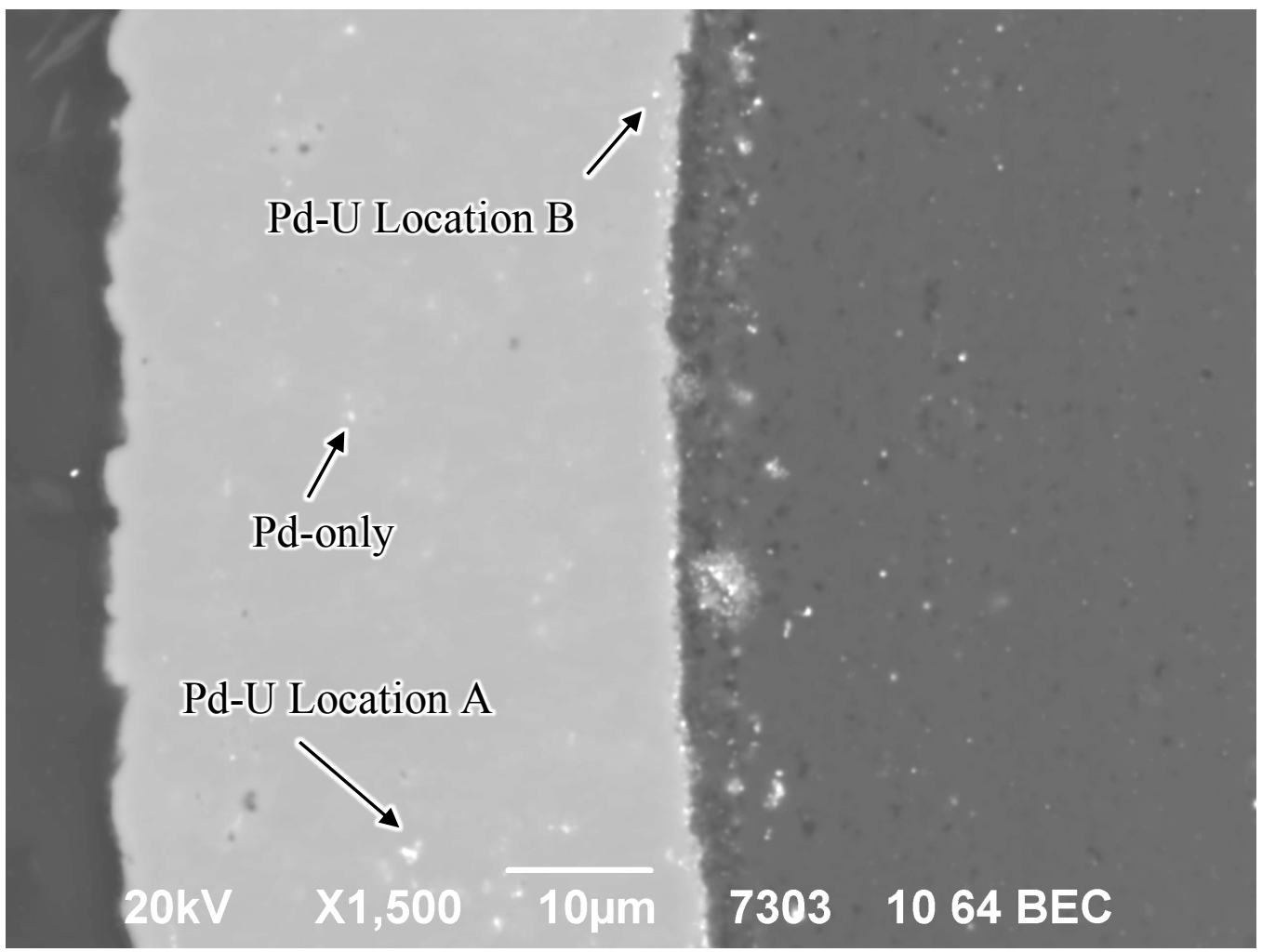

Figure 27. Pd-only and Pd-U features in the SiC layer of low-silver Particle 642-RS26 $\left({ }^{110 \mathrm{~m}} \mathrm{Ag} \mathrm{M} / \mathrm{C}<0.31\right)$. 


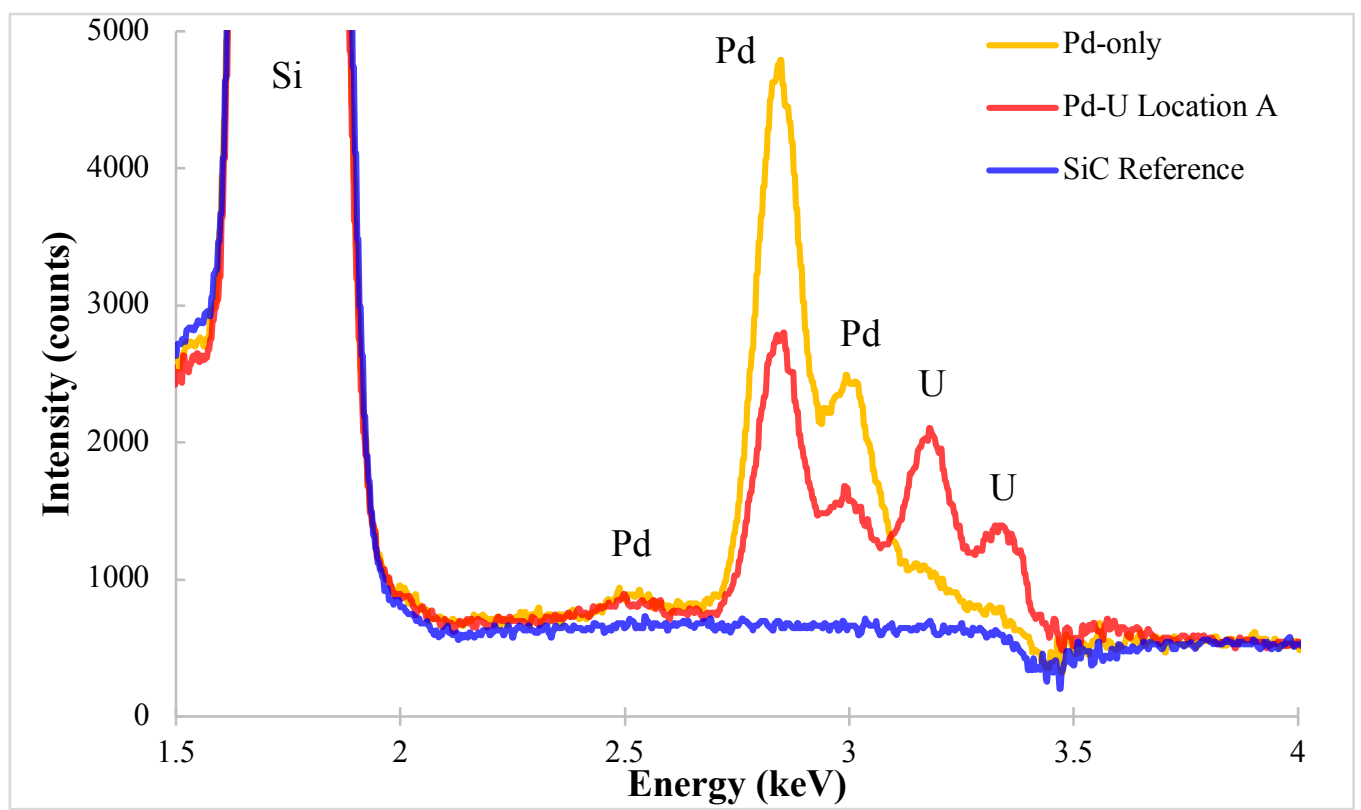

Figure 28. EDS spectra of Point-ID locations centered on Pd-only and Pd-U features shown in Figure 27 for low-silver Particle 642-RS26 $\left({ }^{(10 \mathrm{~m}} \mathrm{Ag} \mathrm{M} / \mathrm{C}<0.31\right)$.

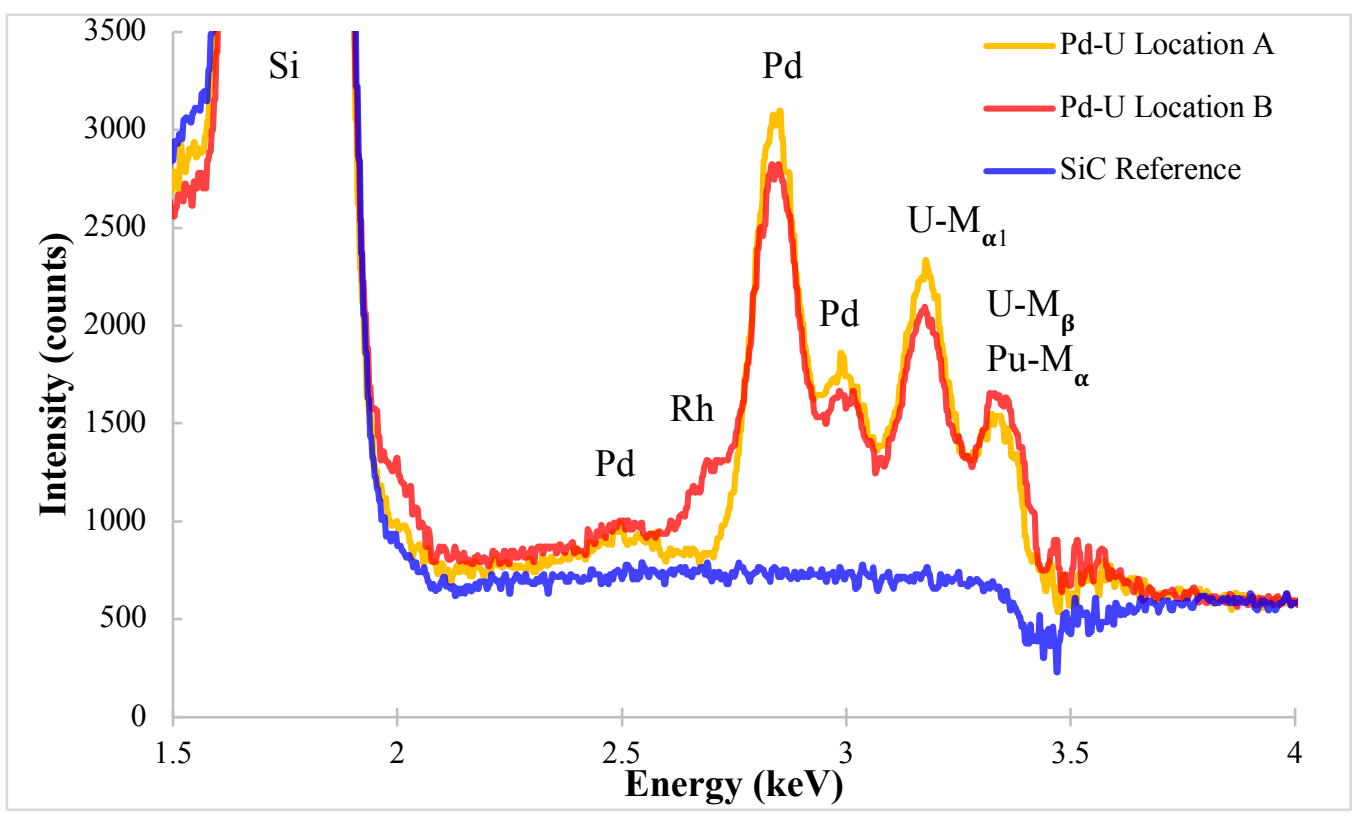

Figure 29. EDS spectra of Point-ID locations centered on Pd-U features shown in Figure 27 for low-silver Particle 642-RS26 $\left({ }^{110 \mathrm{~m}} \mathrm{Ag} \mathrm{M} / \mathrm{C}<\mathbf{0 . 3 1}\right)$.

Also present at the IPyC/SiC boundary in low-silver Particle 642-RS26 were U-Pd and U-Zr features. These features were observed at a lower frequency than the Pd-U features $(\sim 7 \%$ and $\sim 10 \%$ of the measured features near the IPyC/SiC interface, respectively). An example of a $\mathrm{U}-\mathrm{Zr}$ feature at the $\mathrm{IPyC} / \mathrm{SiC}$ boundary is shown in Figure 30 and Figure 31. 


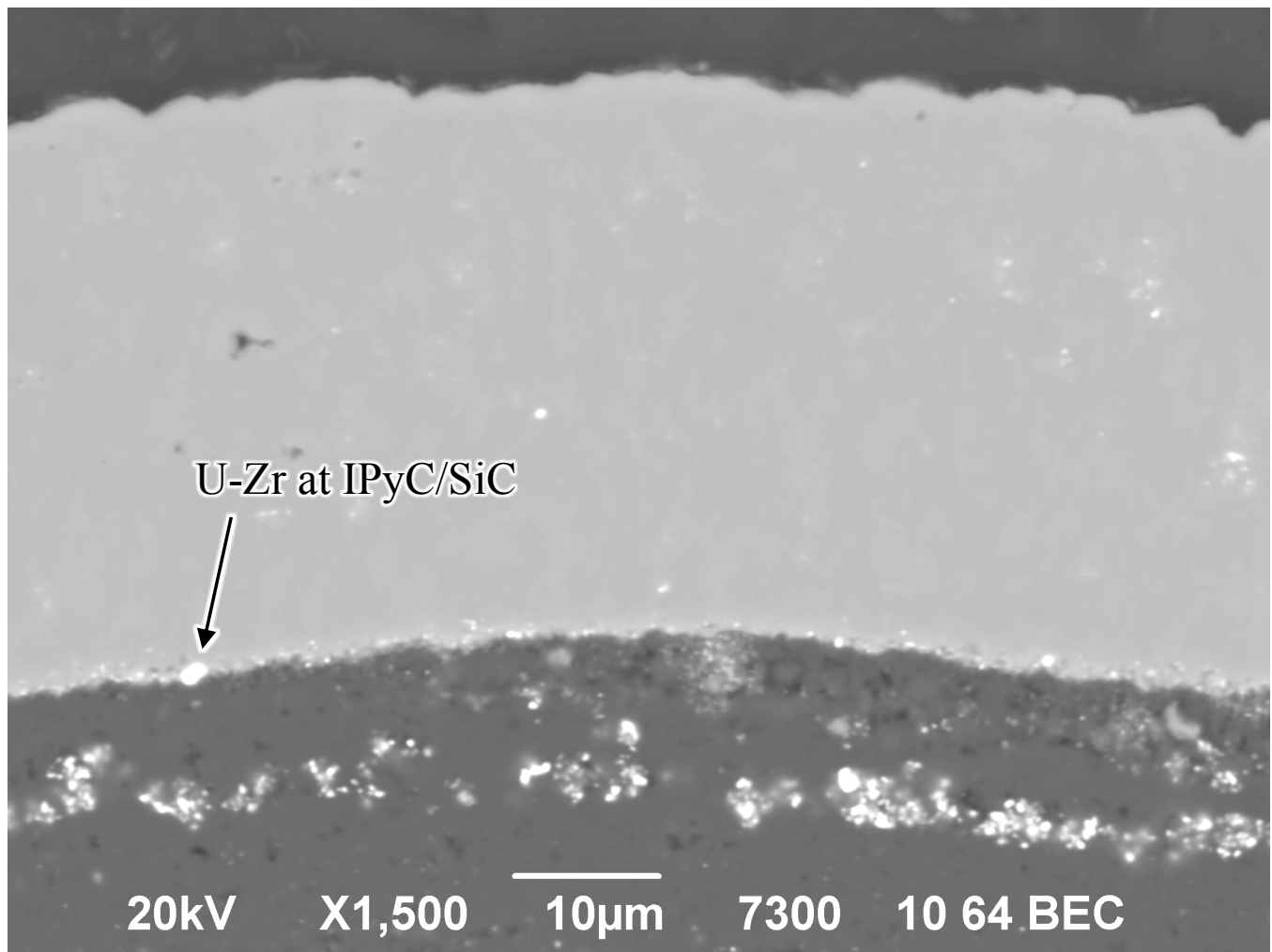

Figure 30. U-Zr features at the IPyC/SiC boundary of low-silver Particle 642-RS26 $\left({ }^{110 \mathrm{~m}} \mathrm{Ag} \mathrm{M} / \mathrm{C}<0.31\right)$.

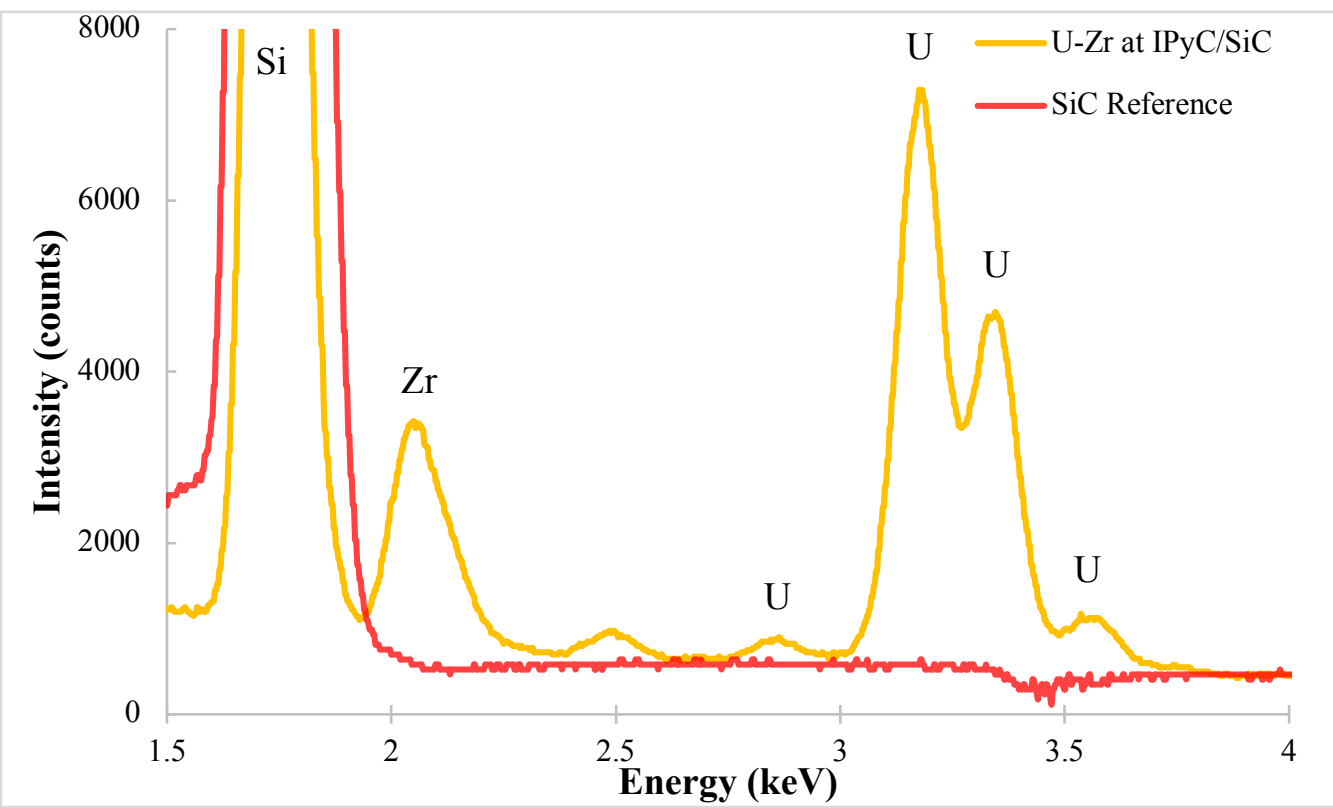

Figure 31. EDS spectra of Point-ID locations centered on U-Zr feature shown in Figure 30 for low-silver Particle 642-RS26 $\left({ }^{110 m} \mathrm{Ag} \mathrm{M} / \mathrm{C}<0.31\right)$.

The large diffuse features and bright segregated features close to the IPyC/SiC boundary on the IPyC side were similar to the features on the $\mathrm{IPyC} / \mathrm{SiC}$ boundary in that they were predominantly $\mathrm{Pd}-\mathrm{U}$ with a lower frequency of U-Pd and U-Zr. Like the Pd-U feature in Figure 27 close to the IPyC/SiC boundary on the $\mathrm{SiC}$ side, trace rhodium and plutonium were identified in near boundary features on the IPyC side. A noted difference was the elevated presence of cesium and barium in the features in this IPyC/SiC interfacial region. Figure 32 shows a large feature close to the IPyC/SiC boundary on the IPyC side in 
Particle 642-RS26 and Figure 33 shows an EDS spectrum from this feature. The intensity of the Si $\mathrm{K}_{\alpha 1}$ peak indicates silicon in the area containing this feature, suggesting that the constituents have likely formed silicides and may have interacted with $\mathrm{SiC}$ infiltrating into the IPyC layer.

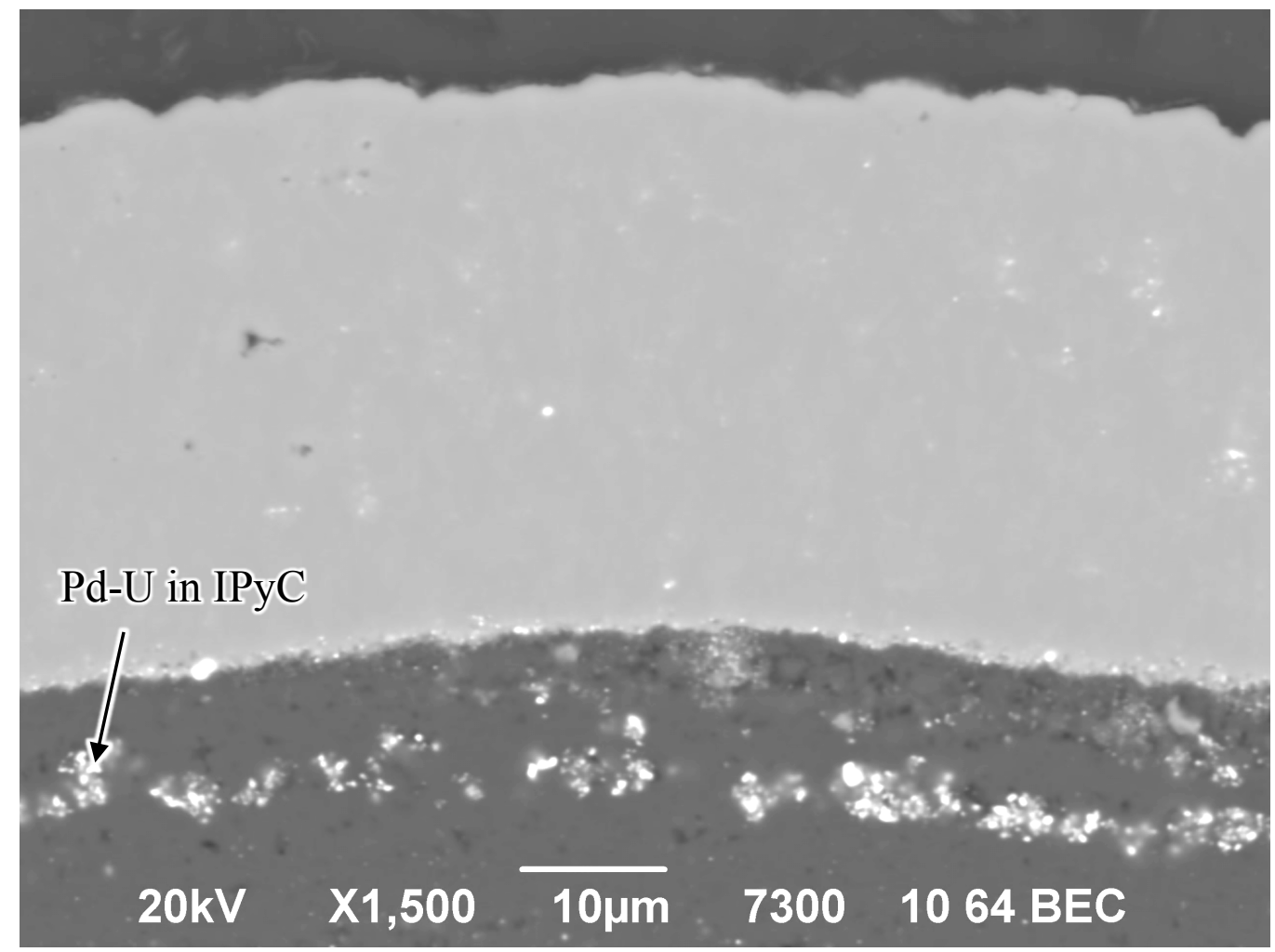

Figure 32. Pd-U feature in the IPyC near the IPyC/SiC boundary of low-silver Particle 642-RS26 $\left({ }^{110 \mathrm{~m}} \mathrm{Ag} \mathrm{M} / \mathrm{C}<0.31\right)$.

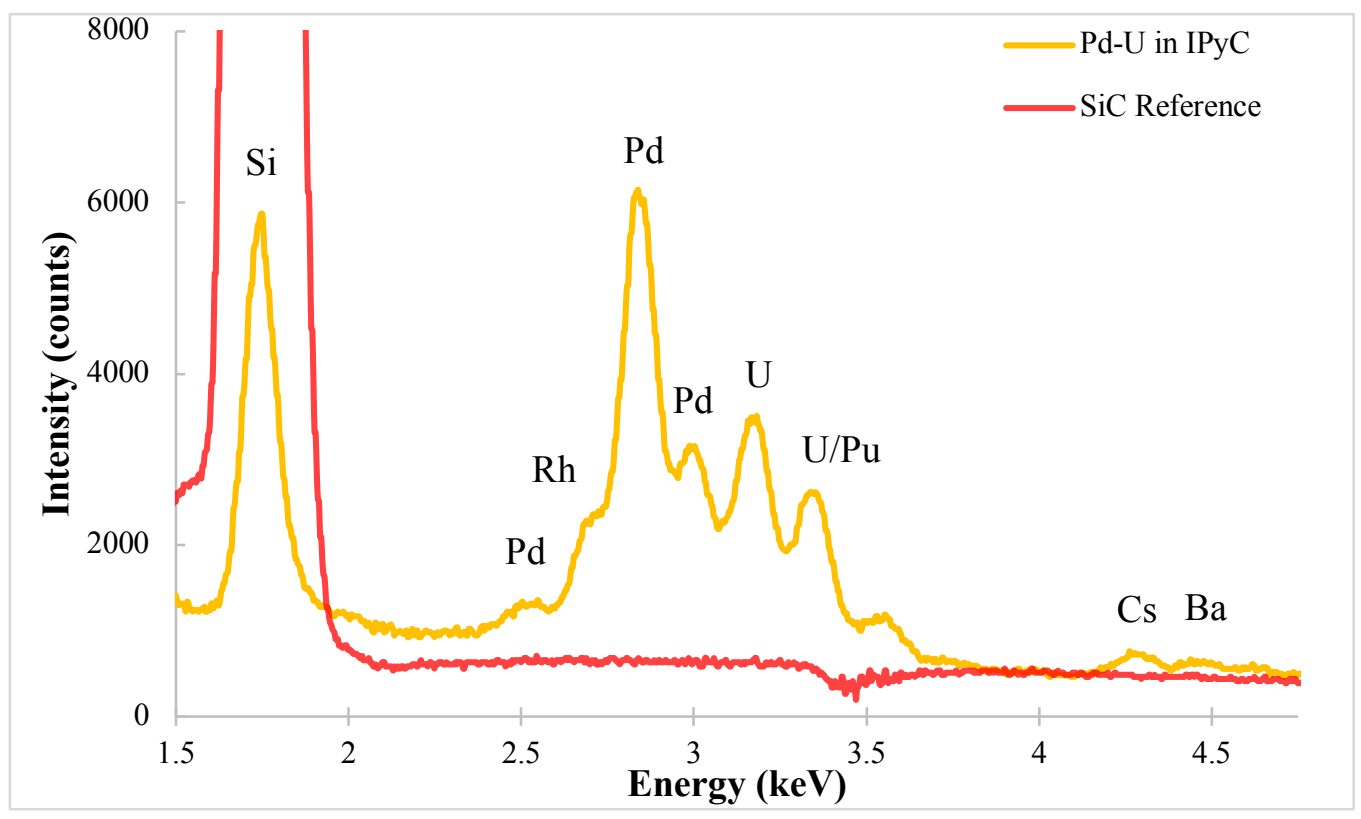

Figure 33. EDS spectra of Point-ID locations centered on Pd-U feature shown in Figure 32 for low-silver Particle 642-RS26 $\left({ }^{110 \mathrm{~m}} \mathrm{Ag} \mathrm{M} / \mathrm{C}<0.31\right)$. 
The features observed in the particles with average-silver (642-RS18, 642-RS44) and high-silver (642-RS23, 642-RS27) were predominantly Pd-U features. No Pd-only features were observed. In lowsilver Particle 642-RS26, the Pd-only features were observed in the SiC more than $5 \mu \mathrm{m}$ from the $\mathrm{IPyC} / \mathrm{SiC}$ boundary. For the average and high-silver particles no high- $\mathrm{Z}$ features were observed in this region. No obvious differences in feature composition were observed between the Pd-U features in the average and high-silver particles, and the features were similar to the Pd-U features observed in the lowsilver particle near the IPyC/SiC boundary in that they included minor concentrations of additional fission products. A comparison of EDS spectra from Pd-U features in the IPyC near the IPyC/SiC boundary of low-silver Particle 642-RS26 and high-silver Particle 642-RS27 is provided in Figure 34. The primary difference was the rhodium peak (observed as a shoulder off the $\mathrm{Pd} \mathrm{L}_{\alpha 1}$ peak at $2.696 \mathrm{keV}$ ), which was not as prevalent in the average and high-silver particles. The standardless analysis routine also identified plutonium in a majority of features, however the same overlap issues discussed earlier are relevant.

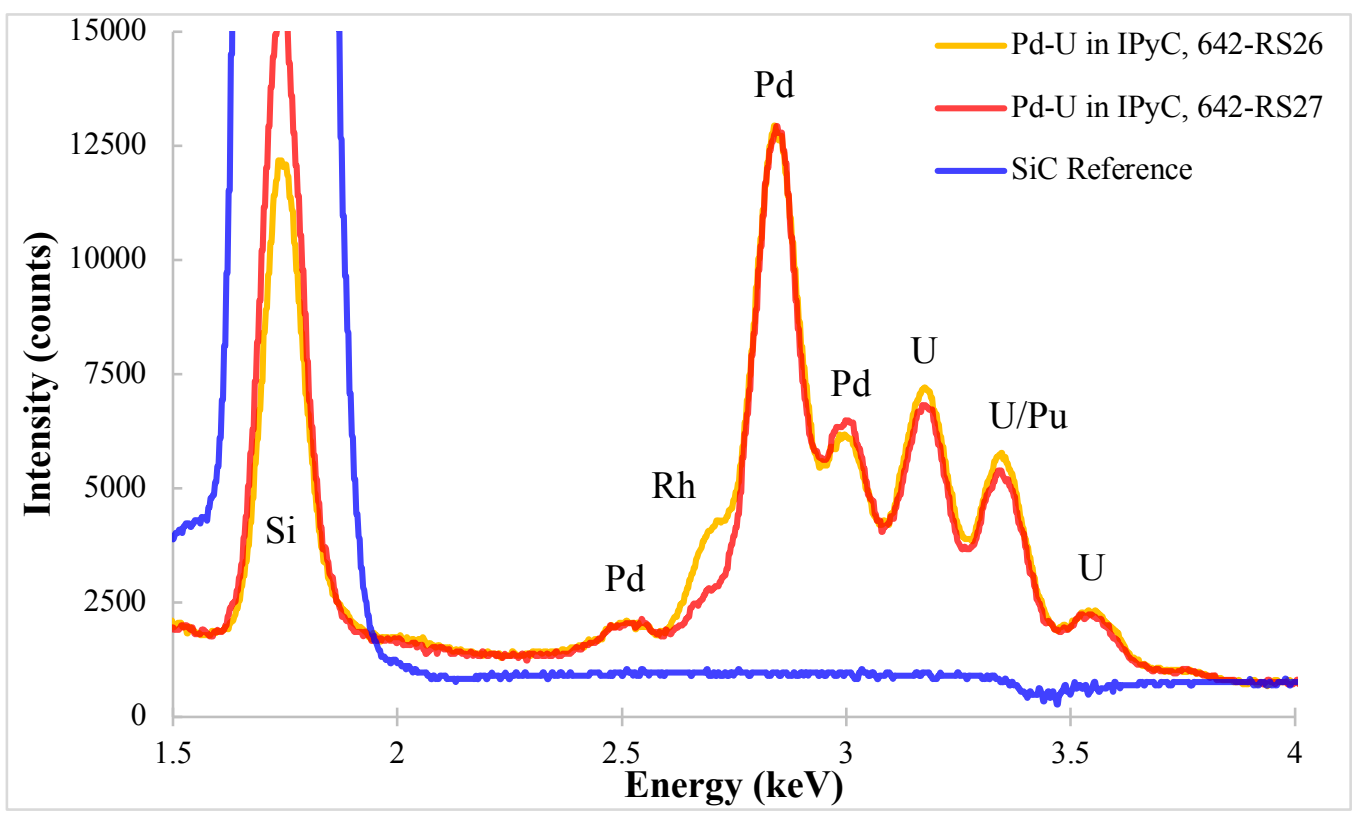

Figure 34. EDS spectra of Pd-U IPyC near the IPyC/SiC boundary for low-silver Particle 642-RS26 and high-silver Particle 642-RS27.

An example of select features near the IPyC/SiC boundary of average-silver Particle 642-RS44 are shown in Figure 35 with associated spectra in Figure 36. The Pd-U features exhibited a variation in intensity of palladium and uranium, with cesium and barium observed in the IPyC layer that was consistent for all average and high-silver particles. The feature in the IPyC layer produced an elevated Si $\mathrm{K}_{\alpha 1}$ peak as observed in Figure 33 and indicating silicon in the area containing this feature, suggesting that the constituents have likely formed silicides and may have interacted with $\mathrm{SiC}$ infiltrating into the IPyC layer. 


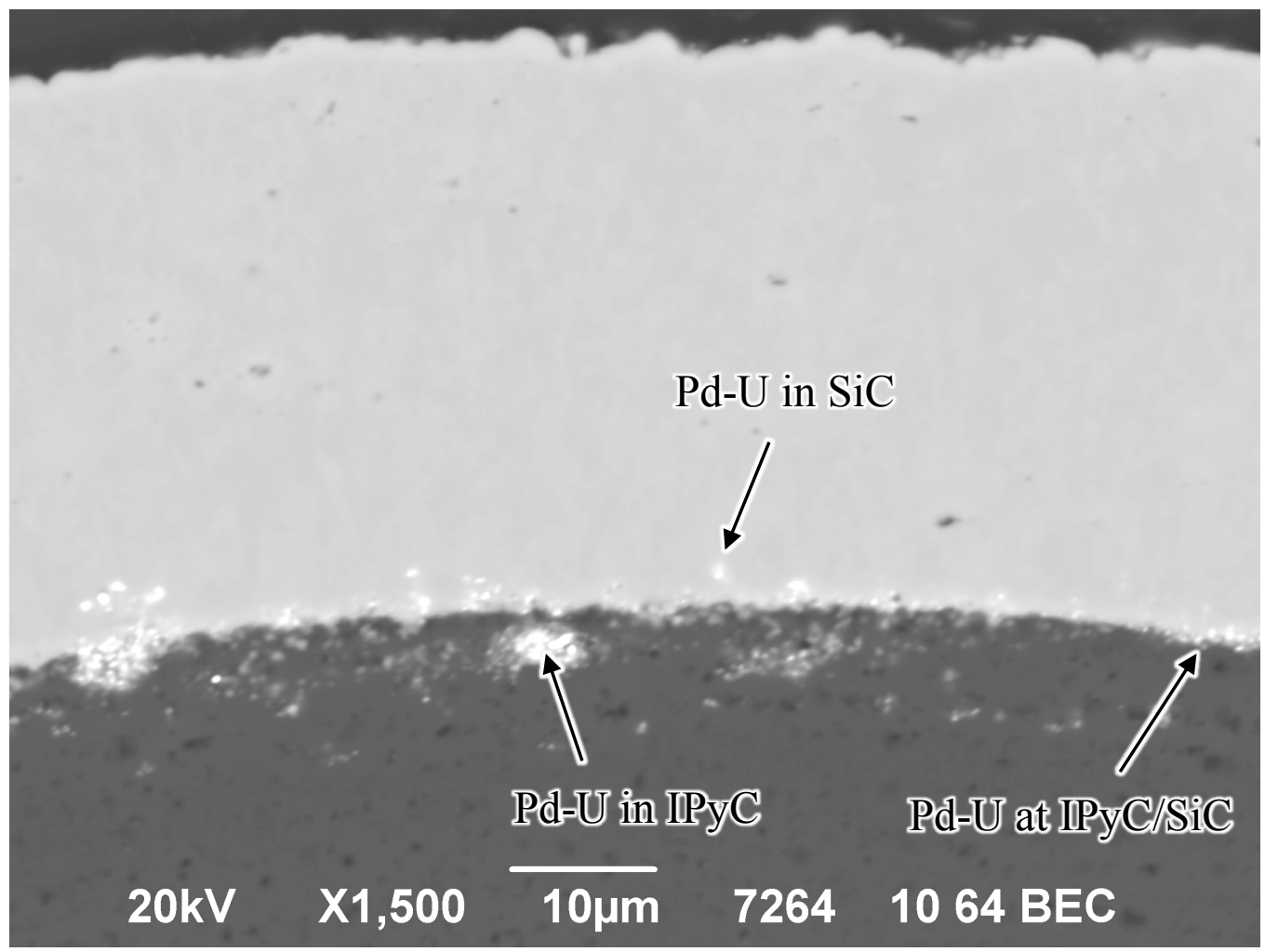

Figure 35. Pd-U features at the IPyC/SiC boundary and near the boundary on either side for average-silver Particle $642-\mathrm{RS} 44\left({ }^{110 \mathrm{~m}} \mathrm{Ag} \mathrm{M} / \mathrm{C}=0.76\right)$.

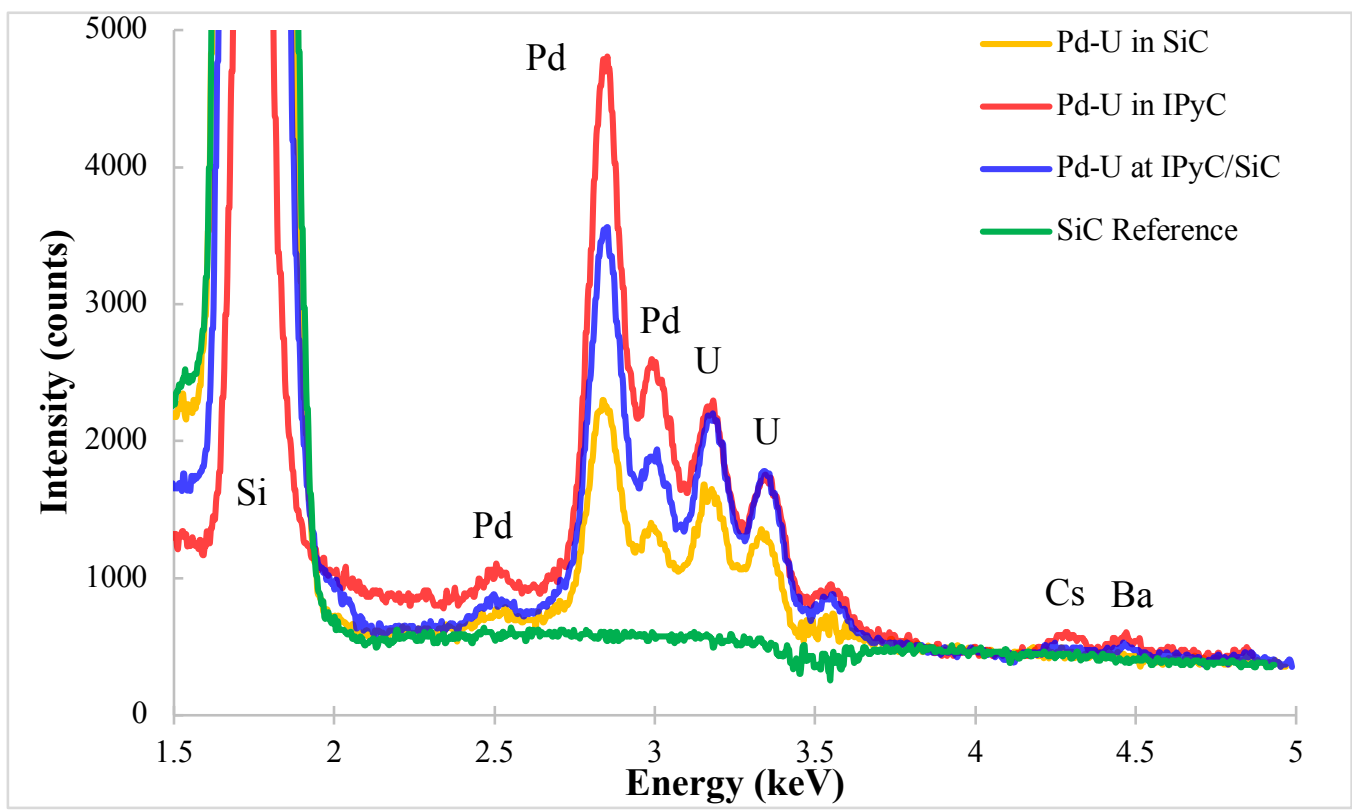

Figure 36. EDS spectra of Point-ID locations centered on Pd-U features shown in Figure 35 for average-silver Particle 642-RS44 $\left({ }^{110 \mathrm{~m}} \mathrm{Ag} \mathrm{M} / \mathrm{C}=0.76\right)$.

The uranium dominant features, U-Pd and U-Zr, were observed at a lower frequency in the average-silver particles relative to the low-silver particle, with $\sim 4 \%$ and $\sim 5 \%$ of the measured features at the IPyC/SiC region being U-Pd and U-Zr, respectively. Figure 37 and Figure 38 show an example of U-Pd and U-Zr feature in Particle 642-RS18. No uranium dominant features were observed in the high-silver particles. 


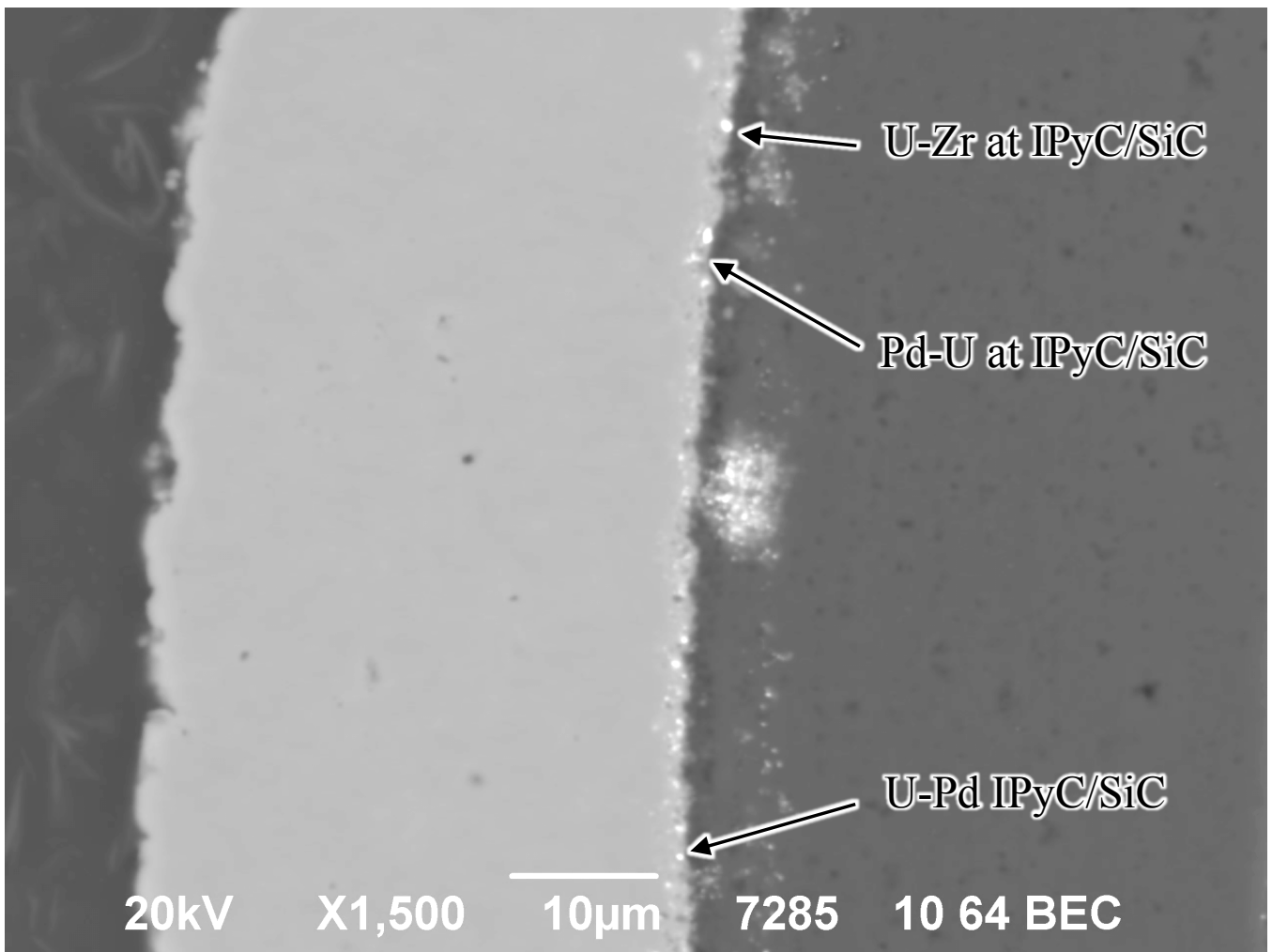

Figure 37. Pd-U features at the IPyC/SiC boundary for average-silver Particle 642-RS18 $\left({ }^{110 \mathrm{~m}} \mathrm{Ag} \mathrm{M} / \mathrm{C}=0.81\right)$.

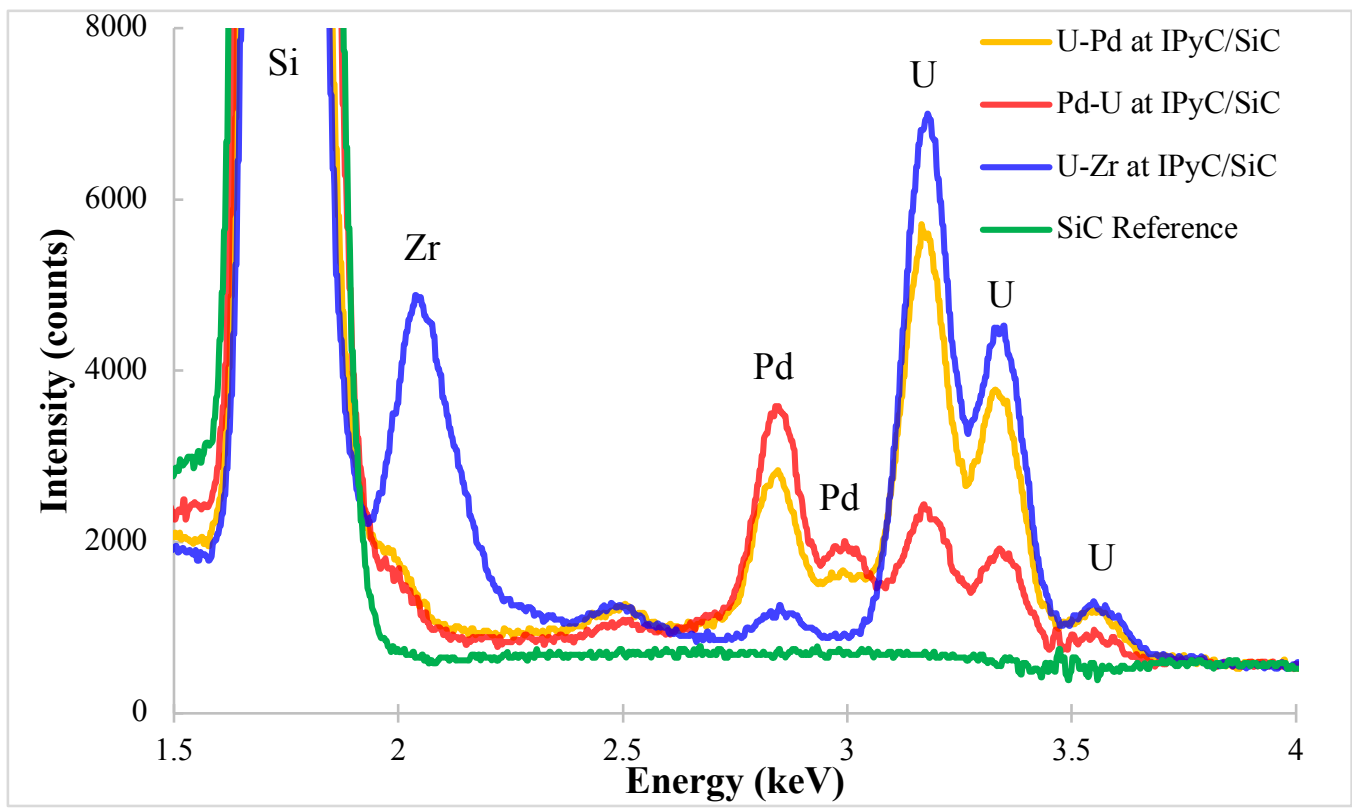

Figure 38. EDS spectra of Point-ID locations centered on features shown in Figure 37 for average-silver Particle 642-RS18 $\left({ }^{110 m} \mathrm{Ag} \mathrm{M} / \mathrm{C}=0.81\right)$.

Compositional analysis of the elevated pileup and high- $\mathrm{Z}$ feature penetration into the $\mathrm{SiC}$ side of the $\mathrm{IPyC} / \mathrm{SiC}$ boundary (Figure 23-Figure 26) indicated the features were similar to other Pd-U features observed close to the IPyC/SiC boundary. An example of various near-boundary features in averagesilver Particle 642-RS44 is shown in Figure 39 with the associated EDS spectra provided in Figure 40. 


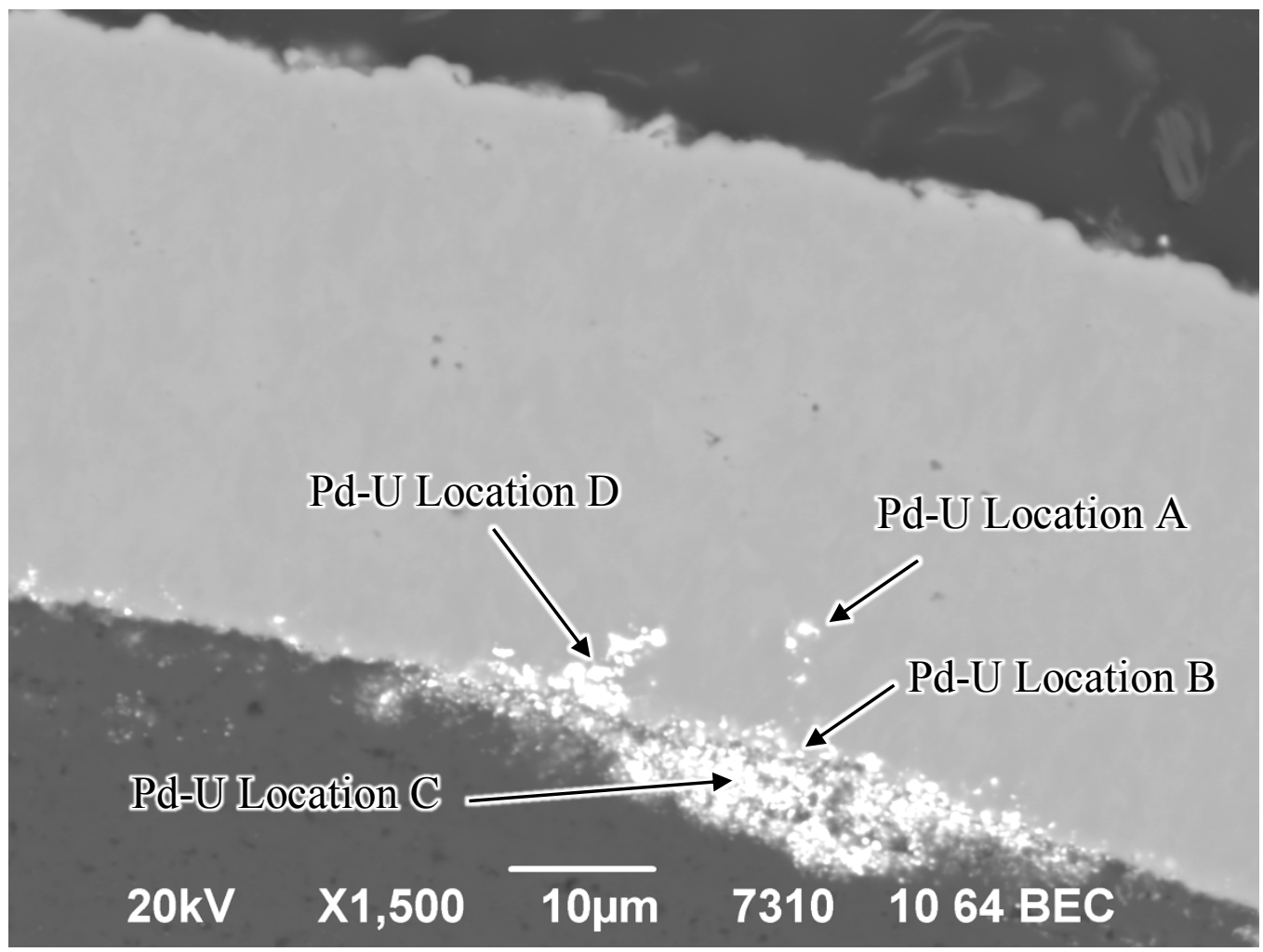

Figure 39. Pd-U features in the locally-elevated, high-Z region near the $\mathrm{IPyC} / \mathrm{SiC}$ boundary of average-silver Particle 642-RS44 $\left({ }^{110 \mathrm{~m}} \mathrm{Ag} \mathrm{M} / \mathrm{C}=0.76\right)$.

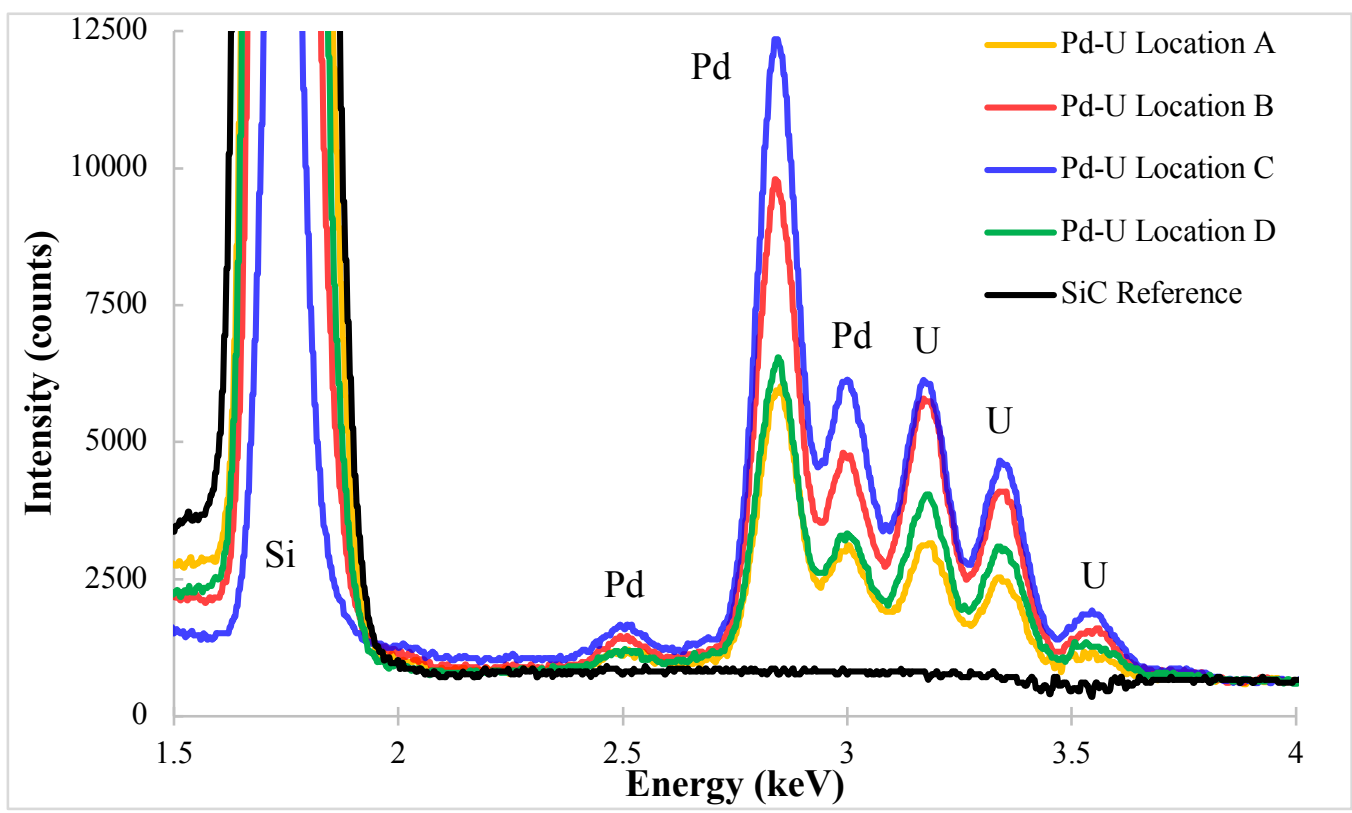

Figure 40. EDS spectra of Point-ID locations centered on Pd-U features shown in Figure 39 for average-silver Particle 642-RS44 $\left({ }^{110 \mathrm{~m}} \mathrm{Ag} \mathrm{M} / \mathrm{C}=0.76\right)$.

Some faint high- $Z$ features observed in the IPyC layer had a unique composition. The features did not produce a strong peak intensity relative to the carbon matrix and were predominantly $\mathrm{U}$ with $\mathrm{Cs}$ and $\mathrm{Ba}$. A majority of features produced strong $\mathrm{Zr}$ peaks as well. A small peak associated with Si internal fluorescence from the SDD EDS detector was associated with all particles, making the confirmation of $\mathrm{Si}$ in this area difficult. The Si artifact also masked potential confirmation of $\mathrm{Sr}$ in the features, but the 
presence of $\mathrm{Sr}$ is likely, based on the peak fitting. Figure 41 shows an example of the IPyC and $\mathrm{U}-\mathrm{Zr}$ feature types associated with the IPyC layer and the corresponding EDS spectra are in Figure 42.

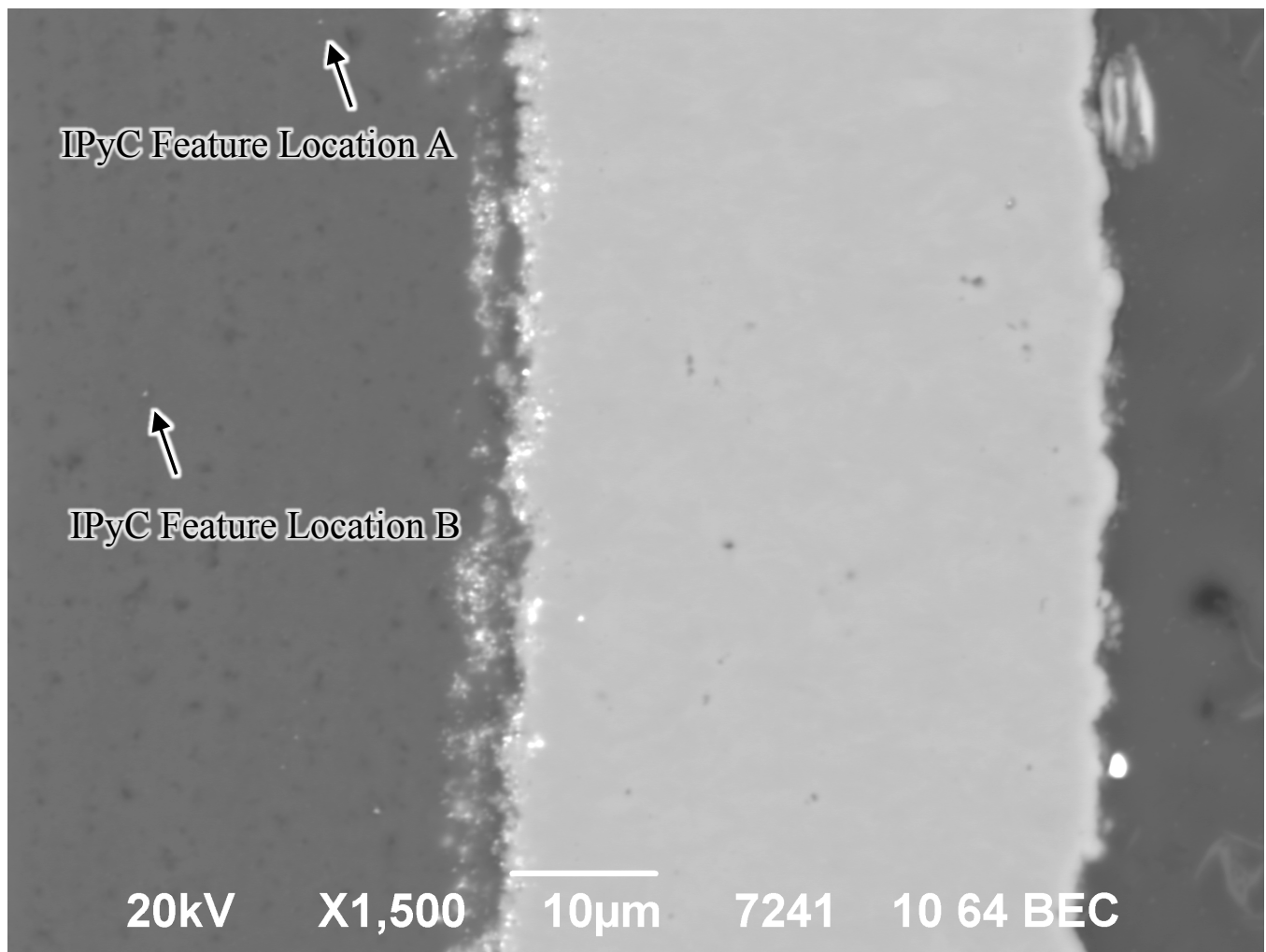

Figure 41. U-IPyC features in high-silver Particle 642-RS23 $\left({ }^{110 \mathrm{~m}} \mathrm{Ag} \mathrm{M} / \mathrm{C}=1.26\right)$.

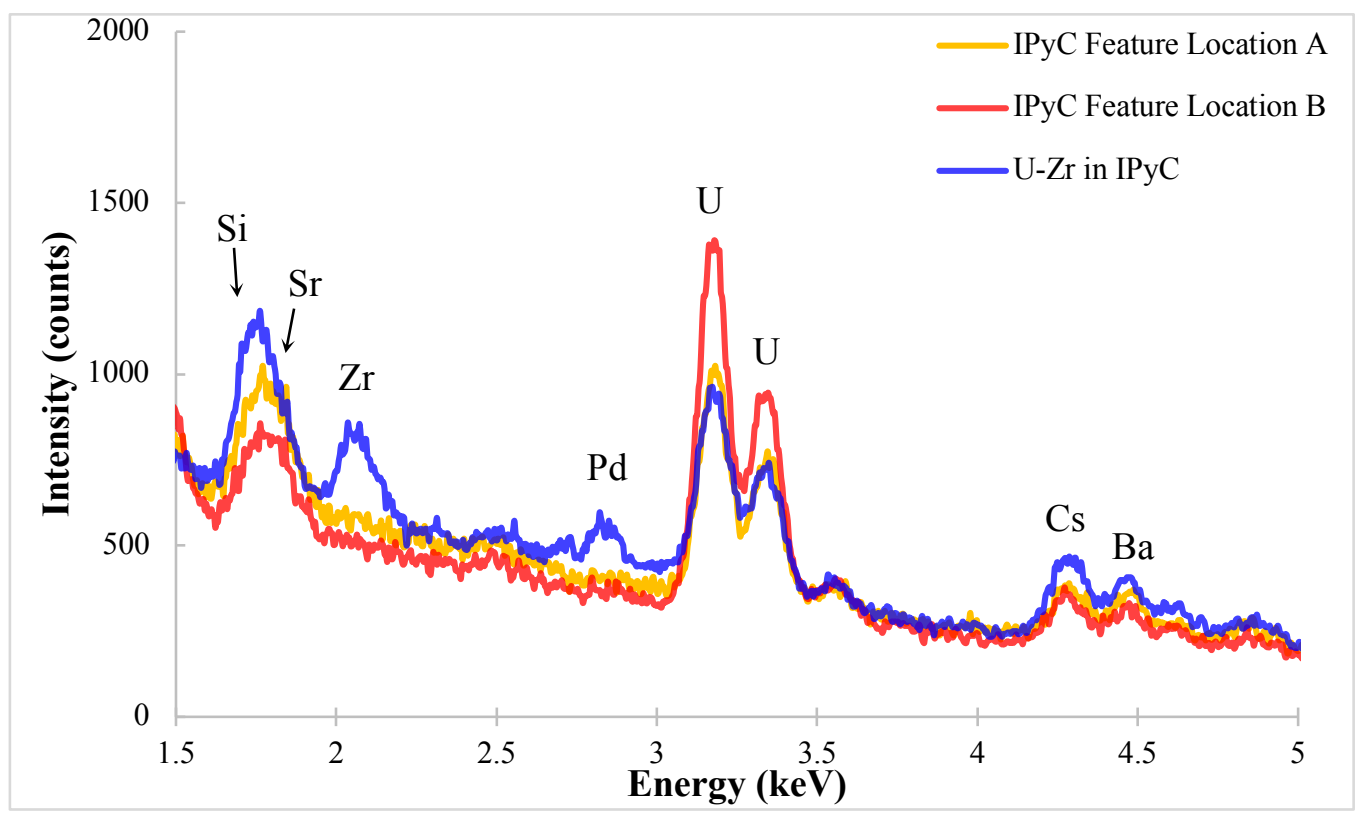

Figure 42. EDS spectra of Point-ID locations centered on IPyC features shown in Figure 41 for high-silver Particle 642-RS23 $\left({ }^{110 \mathrm{~m}} \mathrm{Ag} \mathrm{M} / \mathrm{C}=1.26\right)$ and $\mathrm{U}-\mathrm{Zr}$ feature in IPyC of low-silver Particle 642-RS26. 


\section{X-RAY TOMOGRAPHY}

As described in Section 4, the six-hour IMGA measurement data in Table 6 were used to select particles for microstructural analyses from various regions of the ${ }^{110 \mathrm{~m}} \mathrm{Ag}$ distribution shown in Figure 1. Table 8 lists the particles selected for $\mathrm{x}$-ray tomography using the same calculation method to present the data as was used for Table 7.

Table 8. Particles selected for x-ray tomography

\begin{tabular}{|c|c|c|c|c|c|c|c|}
\hline \multicolumn{8}{|c|}{ Measured versus calculated inventory ${ }^{a}$} \\
\hline Particle & ${ }^{106} \mathbf{R u}$ & ${ }^{110 m} \mathrm{Ag}^{c}$ & ${ }^{125} \mathrm{Sb}$ & ${ }^{134} \mathrm{Cs}$ & ${ }^{137} \mathrm{Cs}$ & ${ }^{144} \mathrm{Ce}$ & ${ }^{154} \mathbf{E u}$ \\
\hline 642-RS28 & 1.39 & 0.42 & 0.89 & 1.01 & 0.82 & 1.27 & 1.04 \\
\hline 642-RS16 & 1.06 & 0.79 & 0.75 & 0.94 & 1.05 & 0.99 & 0.86 \\
\hline 642-RS35 & 1.00 & 0.87 & 0.70 & 1.00 & 1.04 & 1.00 & 0.89 \\
\hline
\end{tabular}

\begin{tabular}{|c|c|c|c|c|c|c|c|}
\hline \multicolumn{8}{|c|}{ Measured versus average inventory ${ }^{b}$} \\
\hline Particle & ${ }^{106} \mathbf{R u}$ & ${ }^{110 \mathrm{~m}} \mathrm{Ag}^{c}$ & ${ }^{125} \mathrm{Sb}$ & ${ }^{134} \mathrm{Cs}$ & ${ }^{137} \mathrm{Cs}$ & ${ }^{144} \mathrm{Ce}$ & ${ }^{154} \mathbf{E u}$ \\
\hline 642-RS28 & 1.30 & 0.52 & 1.21 & 1.02 & 0.79 & 1.26 & 1.17 \\
\hline 642-RS16 & 1.00 & 0.98 & 1.01 & 0.95 & 1.02 & 0.98 & 0.97 \\
\hline 642-RS35 & 0.94 & 1.07 & 0.95 & 1.00 & 1.01 & 0.99 & 1.00 \\
\hline
\end{tabular}

${ }^{a} \mathrm{M} / \mathrm{C}$ values were adjusted for fissile material and burnup using the normalized ${ }^{137} \mathrm{Cs}$ activity, except for ${ }^{137} \mathrm{Cs}$, which used the normalized ${ }^{144} \mathrm{Ce}$ activity.

${ }^{b}$ Measured versus average activity inventory values were adjusted for fissile material and burnup using the normalized ${ }^{137} \mathrm{Cs}$ activity, except for ${ }^{137} \mathrm{Cs}$, which used the normalized ${ }^{144} \mathrm{Ce}$ activity.

${ }^{c}$ Less than values indicate the ${ }^{110 \mathrm{~m}} \mathrm{Ag}$ activity was below the detection limit.

Figure 43-Figure 45 show orthogonal pairs of x-ray tomograms acquired as described in [Hunn et al. 2013]. Particle 642-RS35 had fractured buffer (Figure 45), while the other two particles' buffer was intact and showed the typical separation from the IPyC. No damage was evident in the IPyC or SiC layers of any of the particles. Particle 642-RS28 had an unusually-high inventory of the measured gamma-emitting isotopes (suggesting higher burnup) and an abnormally-low ${ }^{137} \mathrm{Cs} /{ }^{144} \mathrm{Ce}$ ratio. The ratio of measured to average measured activity is shown in Table 9. X-ray tomography showed that the Particle 642-RS28 kernel size was within the normal range and there was no evidence for SiC failure in the $\mathrm{x}$-ray images. This rules out the possibility that its abnormal inventory was due to an unusually large kernel coupled with minor cesium release. It is possible that Particle 642-RS28 came from another compact (perhaps stuck somewhere on the particle handling equipment and inadvertently mixed in with the Compact 6-4-2 particles). The activities observed in Particle 642-RS28 were in the range of some of the Capsule 2 or 5 particles.

Table 9. Ratio of measured versus average measured activity for particles selected for $x$-ray tomography

\begin{tabular}{|c|c|c|c|c|c|c|c|}
\hline Particle & ${ }^{106} \mathrm{Ru}$ & ${ }^{110 m} \mathrm{Ag}^{c}$ & ${ }^{125} \mathrm{Sb}$ & ${ }^{134} \mathrm{Cs}$ & ${ }^{137} \mathrm{Cs}$ & ${ }^{144} \mathrm{Ce}$ & ${ }^{154} \mathbf{E u}$ \\
\hline 642-RS28 & 1.66 & 0.66 & 1.54 & 1.29 & 1.27 & 1.60 & 1.49 \\
\hline 642-RS16 & 1.02 & 1.01 & 1.04 & 0.97 & 1.03 & 1.01 & 1.00 \\
\hline $642-\mathrm{RS} 35$ & 0.98 & 1.11 & 0.99 & 1.04 & 1.04 & 1.03 & 1.04 \\
\hline
\end{tabular}



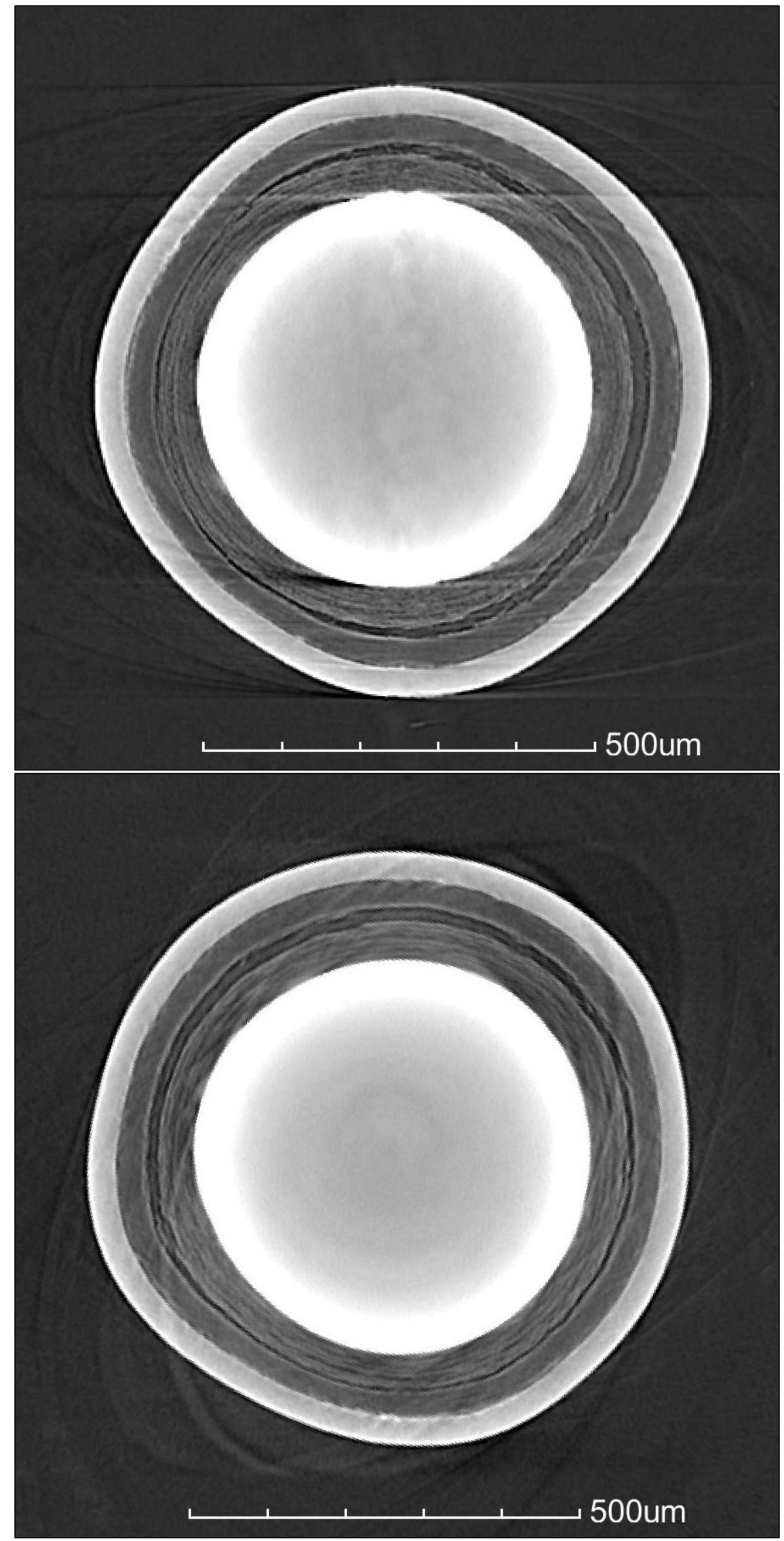

Figure 43. Orthogonal oblique tomograms through center of Particle 642-RS28. 

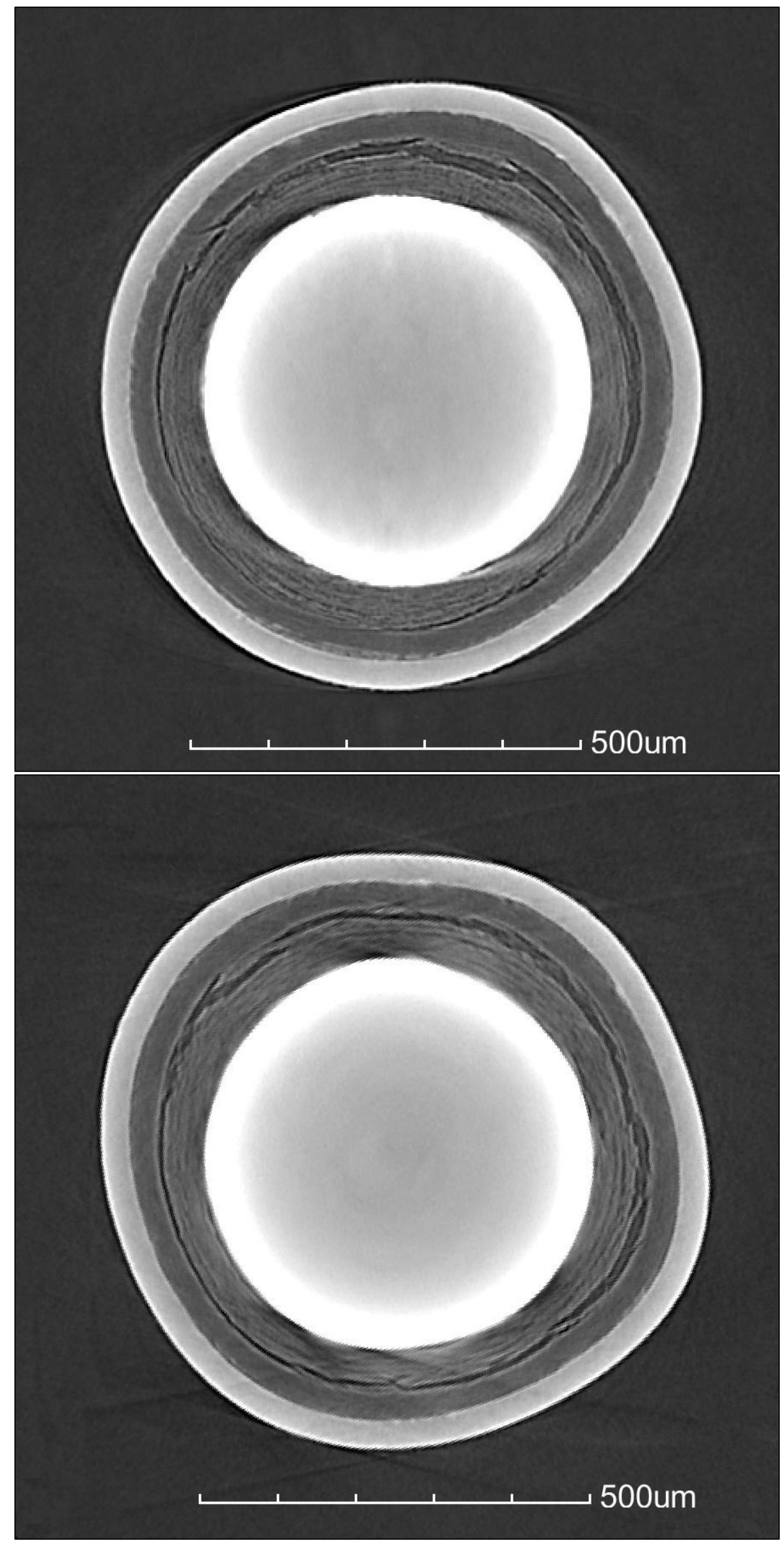

Figure 44. Orthogonal oblique tomograms through center of Particle 642-RS16. 

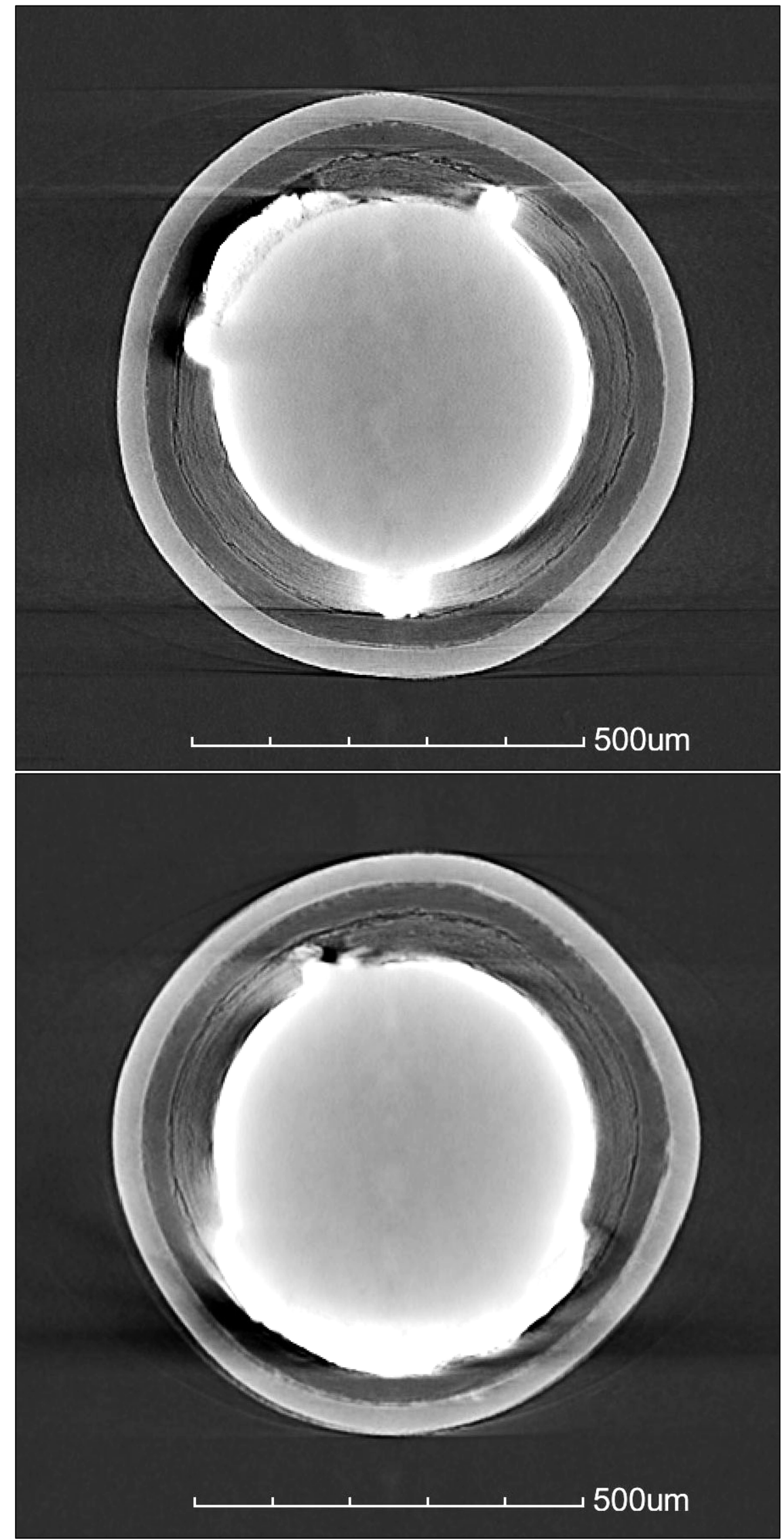

Figure 45. Orthogonal oblique tomograms through center of Particle 642-RS35. 


\section{CONCLUSION}

Safety testing at $1600^{\circ} \mathrm{C}$ was completed on AGR-2 UCO Compact 6-4-2 and previously reported in [Hunn et al. 2017]. After safety testing, destructive PIE was completed. The compact was deconsolidated, and leach-burn-leach analysis performed to measure exposed fission products. The exposed fraction of uranium and plutonium was very low in both the pre-burn leach (no defective or failed TRISO) and postburn leach (no defective or failed $\mathrm{SiC}$ ). Silver, europium and a few other lanthanides were the only exposed fission products detected at significant levels.

Six-hour gamma counting with the IMGA showed the typically-broad distribution of silver retention in individual particles. Particles were selected with various retention characteristics and SEM/EDS analysis showed several relationships between the amount of silver released from the particles and the distribution of fission product near the $\mathrm{IPyC} / \mathrm{SiC}$ boundary and across the $\mathrm{SiC}$ layer. Some chemical interaction between the $\mathrm{SiC}$ layer and palladium and uranium was evident. This $\mathrm{SiC}$ attack most likely occurred during safety testing at $1600^{\circ} \mathrm{C}$ as it was more advanced than is typically observed in as-irradiated UCOTRISO particles with no SiC failure [Hunn et al. 2014; Demkowicz et al. 2015]. 


\section{REFERENCES}

Barnes, C.M. and D.W. Marshall. 2009. FY 2009 Particle Fabrication and Coater Test Report. INL/EXT-09-16545, Revision 0. Idaho Falls, Idaho: Idaho National Laboratory.

Collin, B.P. 2014. AGR-2 Irradiation Test Final As-Run Report. INL/EXT-14-32277, Revision 2. Idaho Falls, Idaho: Idaho National Laboratory.

Demkowicz, P.A. 2013. AGR-2 Post Irradiation Examination Plan. PLN-4616, Revision 0. Idaho Falls, Idaho: Idaho National Laboratory.

Demkowicz, P.A., J.D. Hunn, R.N. Morris, I.J. van Rooyen, T.J. Gerczak, J.M. Harp, and S.A. Ploger 2015. AGR-1 Post Irradiation Examination Final Report. INL/EXT-15-36407, Revision 0. Idaho Falls, Idaho: Idaho National Laboratory.

Gerczak, T.J., J.D. Hunn, R.A. Lowden, T.R. Allen. 2016. "SiC Layer Microstructure in AGR-1 and AGR-2 TRISO Fuel Particles and the Influence of Its Variation on the Effective Diffusion of Key Fission Products." J. Nucl. Mater. 480: 1-14.

Harp, J.M., P.A. Demkowicz, P.L. Winston, and J.W. Sterbentz. 2014. “An analysis of nuclear fuel burnup in the AGR-1 TRISO fuel experiment using gamma spectrometry, mass spectrometry, and computational simulation techniques." Nucl. Eng. Design 278: 395-405.

Hawkes, G.L. 2014. AGR-2 Daily As-Run Thermal Analyses. INL/ECAR-2476, Revision 1. Idaho Falls, Idaho: Idaho National Laboratory.

Hunn, J.D. and R.A. Lowden. 2006. Data Compilation for AGR-1 Variant 3 Coated Particle Composite LEU01-49T. ORNL/TM-2006/022, Revision 0. Oak Ridge, Tennessee: Oak Ridge National Laboratory.

Hunn, J.D. 2010. AGR-2 Fuel Compacts Information Summary: Prepared for the NRC MELCOR Project. ORNL/TM-2010/296, Revision 1. Oak Ridge, Tennessee: Oak Ridge National Laboratory.

Hunn, J.D., F.C. Montgomery, and P.J. Pappano. 2010a. Data Compilation for AGR-2 UCO Variant Compact Lot LEU09-OP2-Z. ORNL/TM-2010/017, Revision 1. Oak Ridge, Tennessee: Oak Ridge National Laboratory.

Hunn, J.D., F.C. Montgomery, and P.J. Pappano. 2010b. Data Compilation for AGR-2 $\mathrm{UO}_{2}$ Compact Lot LEU1 1-OP2-Z. ORNL/TM-2010/055, Revision 1. Oak Ridge, Tennessee: Oak Ridge National Laboratory.

Hunn, J.D., T.W. Savage, and C.M. Silva. 2010. AGR-2 Fuel Compact Pre-Irradiation Characterization Summary Report. ORNL/TM-2010/226, Revision 0. Oak Ridge, Tennessee: Oak Ridge National Laboratory.

Hunn, J.D., T.W. Savage, and C.M. Silva. 2012. AGR-1 Fuel Compact Pre-Irradiation Characterization Summary Report. ORNL/TM-2012/295, Revision 0. Oak Ridge, Tennessee: Oak Ridge National Laboratory.

Hunn, J.D., R.N. Morris, C.A. Baldwin, F.C. Montgomery, C.M. Silva, and T.J. Gerczak. 2013. AGR-1 Irradiated Compact 4-4-2 PIE Report. ORNL/TM-2013/236, Revision 0. Oak Ridge, Tennessee: Oak Ridge National Laboratory.

Hunn, J.D., C.A. Baldwin, T J. Gerczak, F.C. Montgomery, R.N. Morris, C.M. Silva, P.A. Demkowicz, J.M. Harp, S.A. Ploger, I.J. van Rooyen, and K.E. Wright. 2014. "Detection and Analysis of Particles with Failed SiC in AGR-1 Fuel Compacts." Paper HTR2014-31254 in Proceedings of the HTR 2014, Weihai, China, October 27-31, 2014. Also published in Nucl. Eng. Design 360: 36-46. 
Hunn, J.D., R.N. Morris, C.A. Baldwin, and F.C. Montgomery. 2016. Safety Testing of AGR-2 UCO Compacts 5-2-2, 2-2-2, and 5-4-1. ORNL/TM-2016/423, Revision 0. Oak Ridge, Tennessee: Oak Ridge National Laboratory.

Hunn, J.D., R.N. Morris, C.A. Baldwin, Z.M. Burns, F.C. Montgomery, and D.J. Skitt. 2017. Safety Testing of AGR-2 UCO Compacts 6-4-2 and 2-3-1. ORNL/TM-2017/439, Revision 0. Oak Ridge, Tennessee: Oak Ridge National Laboratory.

Hunn, J.D., T.J. Gerczak, F.C. Montgomery, D.J. Skitt, C.A. Baldwin, G.W. Helmreich, B.D. Eckhart, and J.A. Dyer. 2018. AGR-2 As-Irradiated UCO Compact 5-4-2 PIE Report. ORNL/TM-2018/863, Revision 0. Oak Ridge, Tennessee: Oak Ridge National Laboratory.

Lowden, R.A. 2006. Fabrication of Baseline and Variant Particle Fuel for AGR-1. ORNL/CF-2006/02, Revision 0. Oak Ridge, Tennessee: Oak Ridge National Laboratory.

Morris, R.N., P.A. Demkowicz, J.D. Hunn, C.A. Baldwin, and E.L. Reber. 2014. "Performance of AGR-1 High Temperature Reactor Fuel During Post-Irradiation Heating Tests." Paper HTR2014-31135 in Proceedings of the HTR 2014, Weihai, China, October 27-31, 2014. Also published in Nucl. Eng. Design 360: 24-35.

Morris, R.N., J.D. Hunn, C.A. Baldwin, F.C. Montgomery, T.J. Gerczak, and P.A. Demkowicz. 2016. "Initial Results from Safety Testing of US AGR-2 Irradiation Test Fuel." Paper HTR2016-18574. Proc. 8th International Topical Meeting on High Temperature Reactor Technology (HTR-2016), Las Vegas, Nevada, November 6-10, 2016.

Phillips, J.A., C.M. Barnes, and J.D. Hunn. 2010. "Fabrication and Comparison of Fuels for Advanced Gas Reactor Irradiation Tests." Paper HTR2010-236 in Proceedings of the 5th International Topical Meeting on High Temperature Reactor Technology, HTR 2010, Prague, Czech Republic, October 18 20, 2010.

Sterbentz, J.W. 2014. JMOCUP As-Run Daily Depletion Calculation for the AGR-2 Experiment in the ATR B-12 Position. ECAR-2066, Revision 2. Idaho Falls, Idaho: Idaho National Laboratory.

van Rooyen, I.J., D.E. Janney, B.D. Miller, P.A. Demkowicz, and J. Riesterer. 2014. "Electron Microscopic Evaluation and Fission Product Identification of Irradiated TRISO Coated Particles from the AGR-1 Experiment, A Preliminary Review.” Nucl. Eng. Design 271: 114-122. 